\title{
WTP Calculation Sheet: Determining the LAW Glass Former Constituents and Amounts for G2 and Acm Models. 24590-LAW-M4C-LFP-00002, Rev. B
}

Prepared for the U.S. Department of Energy

Assistant Secretary for Environmental Management

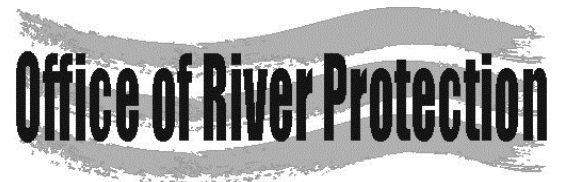

P.O. Box 450

Richland, Washington 99352 
ORP-56511

Revision B

\section{WTP Calculation Sheet: Determining the LAW Glass Former Constituents and Amounts for $\mathbf{G} 2$ and Acm Models. 24590-LAW-M4C-LFP-00002, Rev. B}

R. Gimpel

Bechtel National, Inc.

Date Published

June 2002

Prepared for the U.S. Department of Energy

Assistant Secretary for Environmental Management

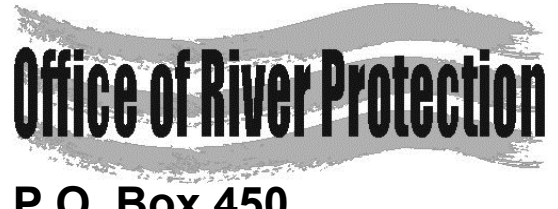

P.O. Box 450

Richland, Washington 99352

\section{APPROVED}

By Julia Raymer at 8:32 am, Dec 16, 2013

Release Approval

Date 
ORP-56511

Revision B

TRADEMARK DISCLAIMER

Reference herein to any specific commercial product, process, or service by tradename, trademark, manufacturer, or otherwise, does not necessarily constitute or imply its endorsement, recommendation, or favoring by the United States Government or any agency thereof or its contractors or subcontractors.

This report has been reproduced from the best available copy.

Printed in the United States of America 
Please complete the following information when submitting a document to PDC.

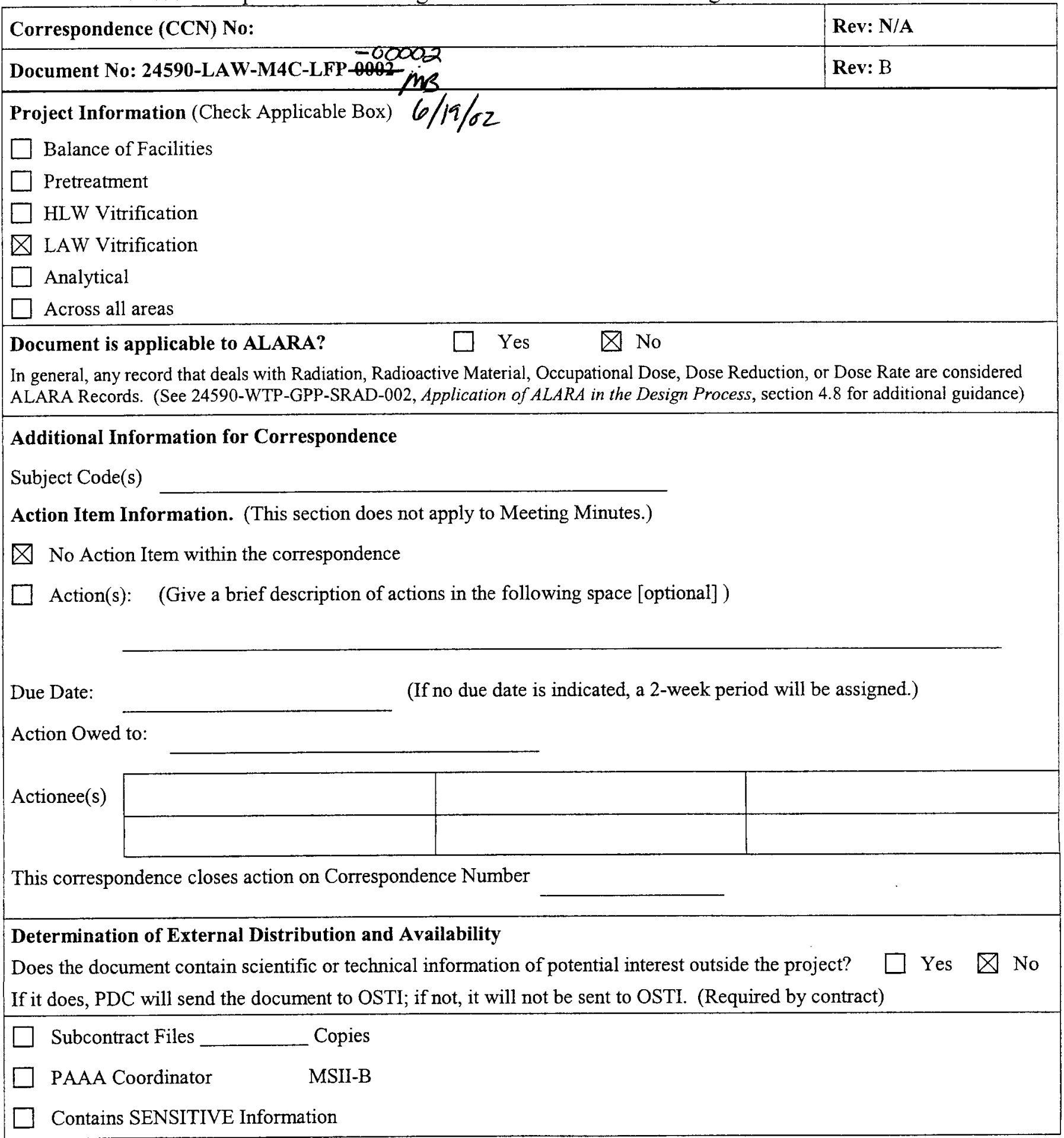

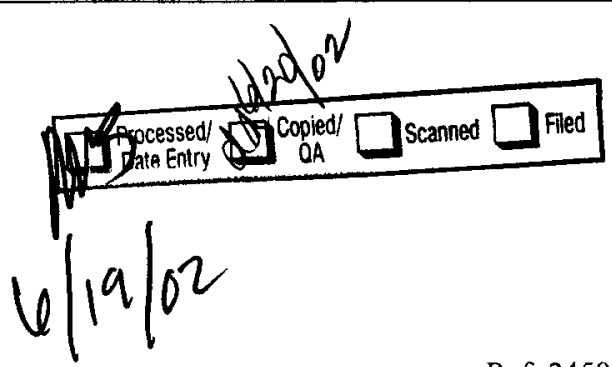




\section{Calculation Cover Sheet}

Sheet i

\begin{tabular}{|c|c|c|c|c|c|c|c|c|c|c|c|}
\hline \multicolumn{8}{|c|}{ RIVER PROTECTION PROJECT-WASTE TREATMENT PLANT } & \multicolumn{4}{|c|}{ JOB NO:: 24590} \\
\hline \multicolumn{8}{|c|}{ CALC NO. 24590-LAW-M4C-LFP-00002 } & \multicolumn{4}{|c|}{ GROUP Process Technology } \\
\hline \multicolumn{12}{|c|}{ ts and Amounts for $\mathrm{G} 2$ and $\mathrm{ACM}$ Models } \\
\hline \multicolumn{6}{|c|}{$\begin{array}{lll}\text { CALCULATION STATUS } & \bigotimes & \text { PRELIMINARY } \\
\text { DESIGNATION } & \square & \text { SUPERSEDED } \\
\end{array}$} & \multicolumn{4}{|c|}{ COMMITTED PRELIMINARY } & \multicolumn{2}{|c|}{$\begin{array}{l}\text { CONFIRMED } \\
\text { VOIDED }\end{array}$} \\
\hline \multicolumn{2}{|c|}{\begin{tabular}{l|} 
COMPUTER \\
PROGRAM/TYPE
\end{tabular}} & $\begin{array}{c}\text { N/A } \\
\square\end{array}$ & \multicolumn{2}{|c|}{$\begin{array}{l}\text { SCP } \\
\text { YES } \square \text { NO }\end{array}$} & \multicolumn{3}{|c|}{$\begin{array}{l}\square \text { STAND-ALONE } \\
\square \text { NETWORKED }\end{array}$} & \multicolumn{2}{|c|}{$\begin{array}{l}\text { PROGRAM NAME } \\
\text { Microsoft Excel }\end{array}$} & \multicolumn{2}{|c|}{$\begin{array}{l}\text { VERSION/RELEASE NO. } \\
97 / \mathrm{SR}-2\end{array}$} \\
\hline \multicolumn{12}{|c|}{ Notes/Comments } \\
\hline \multicolumn{12}{|c|}{$\begin{array}{l}\text { The purpose of this calculation is to determine the LAW glass former recipe and additives with their } \\
\text { respective amounts. The methodology and equations contained herein are to be used in the G2 and ACM } \\
\text { models until better information is supplied by R\&T efforts. }\end{array}$} \\
\hline \multicolumn{12}{|c|}{$\begin{array}{l}\text { This revision includes calculations that determines the mass and volume of the bulk chemicals/minerals } \\
\text { needed per batch. Plus, it contains calculations (for the } G 2 \text { model) to help prevent overflow in LAW Feed } \\
\text { Preparation Vessel. }\end{array}$} \\
\hline B & \multicolumn{3}{|c|}{$\begin{array}{l}\text { Additional Calculations and } \\
\text { Attachments }\end{array}$} & \multicolumn{2}{|l|}{71} & 71 & Rqd & Gimpel & $\begin{array}{l}\text { Jake } \\
\text { Reynolds }\end{array}$ & Opie Bमsk & $05 / 30 / 02$ \\
\hline$A$ & \multicolumn{3}{|c|}{ Initial Issuance } & \multicolumn{2}{|l|}{13} & 13 & $\operatorname{Rod}$ & Gimpel & $\begin{array}{l}\text { Jake } \\
\text { Reynolds }\end{array}$ & Olie Block & $01 / 09 / 02$ \\
\hline NO. & \multicolumn{3}{|c|}{ REASON FOR REVISION } & \multicolumn{2}{|c|}{$\begin{array}{l}\text { TOTAL NO. } \\
\text { OF SHEETS }\end{array}$} & \begin{tabular}{|c|} 
LAST \\
SHEET NO. \\
\end{tabular} & & BY & CHECKED & $\begin{array}{l}\text { APPROVED/ } \\
\text { ACCEPTED }\end{array}$ & DATE \\
\hline \multicolumn{12}{|c|}{ RECORD OF REVISIONS } \\
\hline
\end{tabular}




\section{Contents}

CONTENTS.

1 PURPOSE

2 CRITERIA AND DESIGN INPUTS

3 ASSUMPTIONS.

4 METHODOLOGY.

5 Calculation.

Attachment 1 Table 3.1 Excerpt VSL Glass Development Studies

Attachment 2 Variability in LAW Glass Recipes Determination Spreadsheet - Elements as Oxides.

Corresponding "Formula Displayed" Spreadsheet Attached.

Attachment 3 LAW Glass Oxides vs. SO3 - Difference from Average Glass Composition Plot

Attachment 4 LAW Glass Oxides vs. SO3 Plot

Attachment 5 Variability in LAW Glass Recipes Determination Spreadsheet - Elemental Concentrations Corresponding "Formula Displayed" Spreadsheet Attached.

Attachment 6 LAW Glass Elements vs. Sulfur Plot

Attachment 7 Validation of Use of Microsoft Excel 97 Software

Corresponding "Formula Displayed" Spreadsheet Attached.

Attachment 8 Equations Microsoft Excel 97 Uses for Calculating Trendlines

Attachment 9 Linear Curve Fit of LAW Pilot Runs

Corresponding "Formula Displayed" Spreadsheet Attached.

\section{Purpose}

The purpose of this calculation is to determine the LAW glass former recipe and additives with their respective amounts. The methodology and equations contained herein are to be used the G2 and ACM models until better information is supplied by R\&T efforts.

Revision B contains calculations to make adjustments to input streams and glass former addition amounts to control batch volumes around the LAW Melter Feed Prep Vessel's control volume (or set point) and prevent overflow. These calculation are presented towards the end of the document and are highlighted. The calculations presented in Revision A remain the same. Calculations to determine the amounts of minerals to be added, for the glass formers, is included for tank sizing. Extra supporting documentation and text corrections for Revision A calculations are also included. 


\section{Criteria and Design Inputs}

Some of the preferred recipes for LAW glasses, as developed and tested at The Vitreous State Laboratory (VSL) at The Catholic University in Washington D.C., are given in Attachment 1, which is attached. Attachment 1 is an excerpted Table 3.1 from Document No. 24590-LAW-TP-RT-01-010, LAW Glass Formulation to Support Actual Waste Testing Test Plan, Rev. 0 . These glasses meet all contract requirements and are considered the best formulations thus far. (The inputs needed in Section 5.9 are described in that Section.)

\section{Assumptions}

Not Applicable

\section{Methodology}

With casual comparison of the glass recipes makeup it appeared that the compositions of the recipes follow trends with respect to the sulfate concentration in the glasses. The glass recipes were incorporated into a spreadsheet to determine how closely the recipes followed trends and if they could be modeled. The glass constituents concentrations did follow sulfate concentration. This was investigated by summing up all the glass recipes and finding the average glass composition. Then the difference between each individual glass recipe from the average was plotted. A copy of the plot is shown in Attachment $3 \mathrm{LAW}$ Glass Oxides vs. $\mathrm{SO}_{3}-$ Differences from Average Glass Composition. The plot showed trends for each of the constituents in the glass that could be modeled with reasonable accuracy with respect to sulfate concentration in the glass. Using theses relationships to determine the glass recipe and glass former amounts are described as follows.

\section{Calculation}

\subsection{Graphic Presentation of the Glass Recipe Trends}

This section (Section 5.1) was written only to produce a plot, in Attachment 3, that shows correlation of the glass chemistry with respect to the concentration of sulfate in the glass. The equations developed in the following sections are the ones intended to be used in the models (e.g., G2 and ACM). These equations require less manipulation in the computer.

The LAW glass formulations appear to follow trends that can be modeled with respect to the sulfate concentration in the glass. Sodium happens to be main constituent in the waste, and thus, a main constituent in the glass. Sodium's concentration increases inversely proportional to the sulfate concentration. Later sections use this fact, along with the limiting waste loading characteristic of sulfur, to determine how much glass is made.

The glass formulations for all the envelopes in Attachment $\mathbf{1}$ are incorporated into Columns a through $\mathbf{h}$ in Attachment 2's spreadsheet entitled Variability in LAW Glass Recipes Determination Spreadsheet. The spreadsheet software used was Microsoft Excel 97 on a Compaq ${ }^{\text {TM }}$ Personal Computer. All the calculations are based on wt \% (or 100 parts of glass). The average of these glass formulation was calculated as shown in Column j. Sample calculations will be done for $\mathrm{CaO}$ to show how the spreadsheet calculations functioned. 
Equation 1 shows the math to perform the average calculation for $\mathrm{CaO}$; however, the "average function" was used in the Excel 97 Spreadsheet to give the same results.

$$
\begin{gathered}
\mathrm{CaO} \text { average concentration }=(1.994+1.991+5.065+5.117+6.409+6.746+6.746) / 7=4.85 \mathrm{wt} \% \\
(\text { units }=w \mathrm{t} \%)
\end{gathered}
$$

Then the amount each glass recipe varied, by constituent, from the average glass composition (in Column $\mathbf{j}$ ) was calculated (by the spreadsheet) by subtracting the data in Columns $\mathbf{b}$ through $\mathbf{h}$ from the average in Column $\mathbf{j}$. Results are shown in Columns $\mathbf{k}$ through $\mathbf{q}$.

The $\mathrm{CaO}$ variation calculation is shown here as an example (units are in $\mathrm{wt} \%$ ):

\section{Equation 2}

$$
\begin{array}{ll}
\text { Column } \mathrm{k}= & 1.994-4.85=-2.86 \mathrm{wt} \% \\
\text { Column } \mathrm{l}= & 1.991-4.85=-2.86 \mathrm{wt} \% \\
\text { Column } \mathrm{m}= & 5.065-4.85=0.22 \mathrm{wt} \% \\
\text { Column } \mathrm{n}= & 5.117-4.85=0.27 \mathrm{wt} \% \\
\text { Column } \mathrm{o}= & 6.409-4.85=1.56 \mathrm{wt} \% \\
\text { Column } \mathrm{p}= & 6.746-4.85=1.90 \mathrm{wt} \% \\
\text { Column } \mathrm{q}= & 6.627-4.85=1.78 \mathrm{wt} \%
\end{array}
$$

Those individual constituents that appeared not to follow the trend are shown in underlined in Columns $\mathbf{k}$ through q of Attachment 2. These will be called "outliers". The outlier in Column $\mathbf{k}$ was left unchanged. The outliers in Columns $\mathbf{m}$ through $\mathbf{q}$ were replaced by the average the adjacent values to allow a better fit. The outlier in Column $q$ was set to the same value in Column $\mathbf{p}$. The outliers were modified to visually show a better curve fit. Modifying the outliers can be justified because other VSL glass recipes can be found (I. S. Muller February 23, 2001) that approximate the adjusted values that are not presented in Table 3.1 in Attachment 1.

The values (wt $\%$ of oxides in the glass) in Columns $\mathbf{k}$ through $\mathbf{q}$ were plotted with respect to the $\mathrm{SO}_{3}$ concentration in the glass. It can be seen that the glass constituents follow a linear trend as a function of $\mathrm{SO}_{3}$ content in the glass. The equations for determining the glass recipe and glass former amounts, using the trends shown in this section, are presented in Section 5.3. The outliers were not modified in the equations given in Sections 5.3.

\subsection{Validation of use of Microsoft Excel 97 Software for Linear Regression}

Curve fitting the data, using summation and linear regression, is considered the most taxing function performed by Microsoft Excel 97 in this Engineering Calculation. Attachment 7 shows linear curve fitting of fictitious data using Microsoft Excel 97 and a Hewlett Packard 32SII handheld calculator. Both gave the same results. The curve fitting function used called a Trendline function in Microsoft Excel 97. Equations used in the Trendline function is given in Attachment 8.

\subsection{Determining Glass Recipe Based on $\mathrm{SO}_{3}$ Concentration in the Glass}

As stated above, the glass formulations for all the envelopes in Attachment 1 are incorporated into Columns a through h in Attachment 2's spreadsheet entitled Variability in LAW Glass Recipes Determination Spreadsheet. 
These constituents were plotted with respect to $\mathrm{SO}_{3}$ concentration in the glass. Linear regression was performed (using Microsoft Excel 97's Trendline function) for each constituent in the glass and the line that best fits each constituent's data was placed on a plot shown in Attachment 4. Also, the linear equation, which is the result of linear regression, for the each line was placed on the chart. $\mathrm{R}^{2}$ values as calculated by the Microsoft Excel 97's Trendline function are also included on the chart. For example, the linear equation for $\mathrm{Na}_{2} \mathrm{O}$ is:

$$
\begin{aligned}
& \mathrm{Na}_{2} \mathrm{O}=-20.321 * \mathrm{SO}_{3}+22.3690 \quad \text { (units wt\%) } \\
& \mathrm{R}^{2}=0.9405 \quad \text { (unitless) }
\end{aligned}
$$

Equation 3

From the linear equations one can calculate a LAW glass formulation with respect to sulfate concentration in the glass. This was done in the bottom half of spreadsheet in Attachment 2. In the spreadsheet, the constituent is listed in Column a. The slope and intercept for the linear equations (taken from Attachment 4) are given in Columns $\mathbf{b}$ and $\mathbf{c}$. Then using these linear equations the glass composition for $\mathrm{SO}_{3}$ concentrations 0.10 to 1.00 wt $\%$ were calculated in Columns e through $\mathbf{n}$. The glass constituents in the glass recipes summed up to nearly 100 wt $\%$, showing good correlation. Plus, the concentration of the constituents appear to be between bounds of the acceptable glasses made at VSL (Table 3.1, Attachment 1) as shown in the plots in Attachment 4.

\section{4 "Formula Displayed" Copies of Spreadsheets}

"Formula displayed" copies of the spreadsheets used in the Engineering Calculation are attached behind the "standard/numerical" displayed spreadsheets. These show the formulas, numbers, and logic used in the spreadsheets.

\subsection{Determining Glass Recipe Based on Sulfur Concentration in the Glass}

A second spreadsheet and figure are presented in Attachments 5 and 6. These take the same values in the previous spreadsheet and plots (Attachments 2, bottom half and Attachment 4) and convert the constituents as oxides to elemental concentrations. Thus, the figure is called $L A W$ Glass Elements vs. Sulfur. A sample oxide-to-elemental calculation follows for $\mathrm{CaO}$ in Column d:

$$
\begin{aligned}
\mathrm{CaO}(\text { elemental concentration }) & =\left[40.08(\text { Column c) }) / 56.08(\text { Column b) }]^{*} 1.994(\text { Attachment } 3, \text { Column } \mathrm{b})\right. \\
& =1.425 \mathrm{wt} \%
\end{aligned}
$$

One may notice that the constituents in the glass (see Attachment 5) do not add up to near $100 \mathrm{wt} \%$. This is because oxygen has been left out. Oxygen needs to be accounted and added as a constituent in the glass. This is done by performing a mass balance for oxygen. The amount oxygen needed is that to fully oxidize the cations in the column. This was done in Attachment 5 (second page of attachment).

\subsection{Application of Glass Composition Model}

The above model determines the ratios of the component in wt $\%$ (or 100 parts glass). The following adapts the model to be used in the G2 and ACM models. For example, how much glass will be made if the LAW Concentrate 
SUBJECT: Determining the LAW Glass Former Constituents and Amounts for G2 and ACM Models

contains $120 \mathrm{~kg} \mathrm{SO}_{4}$ and $500 \mathrm{~kg} \mathrm{Na} 2 \mathrm{O}$ equivalents? Also, what are the components amounts in the glass? The following derives the equations where these values can be determined.

Let: $\quad \mathrm{M}_{\text {glass }}=$ mass of glass

$\mathrm{M}_{\mathrm{Na2O}}=\quad \mathrm{Na}_{2} \mathrm{O}$ mass in the LAW Concentrate

$\mathrm{M}_{\mathrm{SO} 4}=\mathrm{SO}_{4}$ mass in the LAW Concentrate

$\mathrm{M}_{\mathrm{SO} 3}=\mathrm{SO}_{3}$ mass in the glass

$\mathrm{C}_{\mathrm{Na} 2 \mathrm{O}}=\quad \mathrm{Na}_{2} \mathrm{O}$ fraction in the glass or the $w t \% \mathrm{Na}_{2} \mathrm{O} / 100$, which is (Equation 3)/100, or

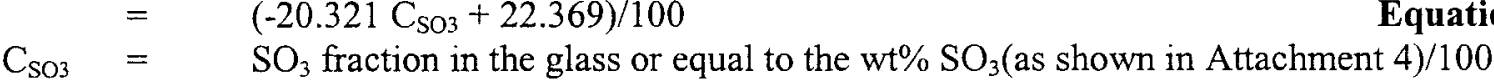

The amounts $\mathrm{M}_{\mathrm{Na} 20}$ and $\mathrm{M}_{\mathrm{SO} 4}$ should be known when the process is running. However, as an the example of using the derived equations that follow, lets assign:

$$
\begin{array}{ll}
\mathrm{M}_{\mathrm{Na} 20} & =500 \mathrm{~kg} \mathrm{Na}_{2} \mathrm{O} \\
\mathrm{M}_{\mathrm{SO} 4} & =120 \mathrm{~kg} \mathrm{SO}_{4}
\end{array}
$$

\subsubsection{Determine the amount of sulfate that will be retained in the glass}

Not all of the sulfate in the LAW Concentrate will be captured by the glass. Some of the sulfate will be lost to the Offgas Treatment System at the melter(s). Equation 5 determines the amount sulfate that goes into the glass. Also, sulfate is normally tracked in the glass or glass recipes as $\mathrm{SO}_{3}$. Whereas, sulfate is tracked in the model as $\mathrm{SO}_{4}$. Equation 5 makes this adjustment for sulfate.

$M_{S O 3}=\left(1-\frac{1}{D F_{\text {sulfate }}}\right)(80.06 / 96.06) M_{S O 4}$

Where: $\mathrm{DF}_{\text {sulfate }}$ is the decontamination factor of sulfate (or sulfur) in the melter.

For example, let $\mathrm{DF}_{\text {sulfate }}=5$, then $20 \mathrm{wt} \%$ of the sulfate is lost to the Offgas

Treatment System and $80 \mathrm{wt} \%$ is retained in the glass. A DF of 5 for sulfate is a reasonable value at this time per VSL studies (Pegg et al. 2000)

$\mathrm{M}_{\mathrm{SO} 4}$ is the sulfate mass in the LAW Concentrate.

$\mathrm{M}_{\mathrm{SO} 3}$ is the sulfate retained in the glass.

$80.06 / 96.06$ is the molar mass ratio of $\mathrm{SO}_{3}$ to $\mathrm{SO}_{4}$

For the example, $\mathrm{M}_{\mathrm{SG}}$ is calculated as follows:

$$
M_{S O 3}=\left(1-\frac{1}{5}\right)(80.06 / 96.06) 120 \mathrm{~kg}=80 \mathrm{~kg}
$$




\subsubsection{Determination of Amount of Glass Produced}

The amount of glass is equal to the following relationships:

$$
\begin{aligned}
& M_{\text {glass }}=M_{\mathrm{SO}_{3}} / \mathrm{C}_{\mathrm{SO} 3}, \text { and also } \\
& M_{\text {glass }}=M_{\mathrm{Na} 2 \mathrm{O}} / \mathrm{C}_{\mathrm{Na} 2 \mathrm{O}}
\end{aligned}
$$

Equation 6

Equation 7

Therefore, $\quad \mathrm{M}_{\mathrm{SO} 3} / \mathrm{C}_{\mathrm{SO} 3}=\mathrm{M}_{\mathrm{Na} 2 \mathrm{O}} / \mathrm{C}_{\mathrm{Na} 2 \mathrm{O}}$

We know that from Equation 4 that $\mathrm{C}_{\mathrm{Na} 2 \mathrm{O}}=\left(-20.321 \mathrm{C}_{\mathrm{SO} 3}+22.369\right) / 100$ (units mass fraction) and this relationship can be substituted into Equation 8.

$$
\frac{M_{\mathrm{SO} 3}}{C_{\mathrm{SO} 3}}=\frac{M_{\mathrm{Na} 2 \mathrm{O}}}{\frac{-20.321 C_{\mathrm{SO} 3}+22.369}{100}} \quad \text { (units mass and mass fraction) }
$$

Equation 9

Solving for $\mathrm{C}_{\mathrm{SO} 3}$ in Equation 9 yields the following:

$$
C_{S O 3}=\frac{0.22369}{\frac{M_{N a 2 O}}{M_{S O 3}}+20.321}=\frac{0.22369}{\frac{500 \mathrm{~kg}}{80 \mathrm{~kg}}+20.321}=0.008419 \text { or } 0.8419 \mathrm{wt} \%
$$

Equation 10

$\mathrm{M}_{\text {glass }}=\mathrm{M}_{\mathrm{SO} 3} / \mathrm{C}_{\mathrm{SO} 3}=80 \mathrm{~kg} / 0.008419=9502 \mathrm{~kg}$ of glass made

Equation 11

Therefore, $\mathrm{C}_{\mathrm{Na} 2 \mathrm{O}}=\mathrm{M}_{\mathrm{Na} 2 \mathrm{O}} / \mathrm{M}_{\text {glass }}=500 \mathrm{~kg} / 9502=0.0526$ or $5.26 \mathrm{wt} \% \mathrm{Na}_{2} \mathrm{O}$ in the glass

Equation 12

\subsection{Glass Former Additive Calculations}

Using the linear equations (given in Attachment 4) the glass composition can be determined. For example, lets calculate the value for $\mathrm{CaO}$. From Attachment 2 the linear equation for $\mathrm{CaO}$ is:

$\mathrm{CaO}=6.2767 \mathrm{SO}_{3}+2.0110 \quad$ (units $\mathrm{wt} \%$ )

Equation 13

From Equation 10, $\mathrm{SO}_{3}=0.8419 \mathrm{wt} \%$. Therefore,

$\mathrm{CaO}=6.2767 * 0.8419+2.0110=7.30 \mathrm{wt} \% \quad$ (units $\mathrm{wt} \%$ )

Equation 14

All the calculated values for the constituents in this Example are shown in Column p of Attachment 2. Some of the glass former constituents may already be in the LAW Concentrate. Therefore, to determine the correct amount of glass former additive for a constituent, the amount in the LAW Concentrate must be subtracted from the amount calculated for making the glass. The Example calculation will be continued with calculating the amount of $\mathrm{CaO}$ glass former additive needed.

$$
\mathrm{M}_{\mathrm{CaO}}=\mathrm{M}_{\text {glass }}{ }^{*} \mathrm{C}_{\mathrm{CaO}}=\mathrm{M}_{\text {glass }}{ }^{*} \mathrm{CaO} / 100=9502 \mathrm{~kg} * 7.30 \mathrm{wt} \% / 100 \mathrm{wt} \%=695 \mathrm{~kg}
$$

\section{Equation 15}


Also note that the glass formers are not added as pure oxides and some adjustments need to be made. For example, $\mathrm{B}_{2} \mathrm{O}_{3}$ is added as $\mathrm{H}_{3} \mathrm{BO}_{3}$ and $\mathrm{Li}_{2} \mathrm{O}$ is added as $\mathrm{Li}_{2} \mathrm{CO}_{3}$. The mass amounts of each is as follows:

$$
\begin{array}{lll}
\mathrm{A}_{\mathrm{H} 3 \mathrm{BO} 3}= & 1.776 \mathrm{~A}_{\mathrm{B} 2 \mathrm{O} 3} & (\text { Example, } 1908 \mathrm{~kg}) \\
\mathrm{A}_{\mathrm{Li2} \mathrm{CO} 3}= & 2.473 \mathrm{~A}_{\mathrm{Li} 2 \mathrm{O}} & (\text { Example, } 1286 \mathrm{~kg})
\end{array}
$$

Equation 17

Equation 18

Therefore, the extra mass that accompanies the glass former addition and extra gases lost to the Offgas Treatment System are as follows:
$\mathrm{A}_{\mathrm{H} 2 \mathrm{O}}=\mathrm{A}_{\mathrm{H} 3 \mathrm{BO} 3}-\mathrm{A}_{\mathrm{B} 2 \mathrm{O} 3}$
(Example, $1908-1075=388 \mathrm{~kg}$ )
Equation 19
$\mathrm{A}_{\mathrm{CO} 2}=\mathrm{A}_{\mathrm{Li} 2 \mathrm{CO} 3}-\mathrm{A}_{\mathrm{Li} 2 \mathrm{O}}$
(Example, $1286-520=766 \mathrm{~kg}$ )
Equation 20

\subsection{Adjusting Flow to Match the Melter Feed Preparation Vessel's Control Volume (G2 Model Only)}

This section applies on to the G2 model because it tracks batches and the Aspen Model does not at this time. The amounts calculated for the batch in the LAW Melter Feed Preparation Vessel are only preliminary since the batch size may be larger than the control volume (set point). Good utilization of the tank is not possible if the batch size is far off from the set point. The following calculations adjust flow into the tank and the amount of glass formers to match the tank's control volume.

Sum all the glass formers amounts presently determined (via Equations 15, 16, 18, and 17) for addition to the tank per Equation 21.

$$
\begin{aligned}
& \mathrm{A}_{\mathrm{A}}=\mathrm{A}_{\mathrm{CaO}}+\mathrm{A}_{\mathrm{SiO} 2}+\mathrm{A}_{\mathrm{H} 3 \mathrm{BO} 3}+\mathrm{A}_{\mathrm{Fe} 2 \mathrm{O} 3}+\mathrm{A}_{\mathrm{Li} 2 \mathrm{CO} 3}+\mathrm{A}_{\mathrm{ZrO} 2}+\mathrm{A}_{\mathrm{TiO} 2}+\mathrm{A}_{\mathrm{Al} 2 \mathrm{O} 3} \\
& +\mathrm{A}_{\mathrm{ZnO}}+\mathrm{A}_{\mathrm{MgO}} \quad \text { (units kg) }
\end{aligned}
$$

Equation 21

To simplify the example calculation let's assume none of the glass former constituents exist in the feed. Therefore, $A_{i}=M_{i}$. For example $A_{C a O}=M_{C a O}=694 \mathrm{~kg}$.

$$
\begin{gathered}
\mathrm{A}_{\mathrm{A}}=695+4631+1908+495+1286+301+53+577+301+263=10,510 \mathrm{~kg} \\
\text { (units kg) }
\end{gathered}
$$

Calculate the Glass Former to Evaporator Concentration fraction:

$$
\mathrm{X}_{\mathrm{Gf}}=\mathrm{A}_{\mathrm{A}} / \mathrm{V}_{\mathrm{EC}}
$$

where: $\mathrm{X}_{\mathrm{Gf}}$ is the mass of glass formers added per unit volume of Evaporator Concentrate to the vessel, $\mathrm{kg} / \mathrm{L}$

$\mathrm{V}_{\mathrm{EC}}$ is the volume of Evaporator Concentrate to the Feed Preparation Vessel, liters (for example, let $\mathrm{V}_{\mathrm{EC}}=6000 \mathrm{~L}$ ) 
SUBJECT: Determining the LAW Glass Former Constituents and Amounts for G2 and ACM Models

Calculate the volume the glass formers occupy in the slurry within the tank:

$$
\mathrm{V}_{\mathrm{GF}}=\left(0.4099 \mathrm{X}_{\mathrm{Gf}}-0.0307\right) \mathrm{V}_{\mathrm{EC}} \text { (units in liters) }
$$

Equation 23

Equation 23 comes from a linear curve fit of a graphical plot of data from recent LAW pilot runs at Duratek in Columbia, MD. The data (Table 24) and linear regression performed on data in Table 24, using the same method as described in Section 5.1, is given in Attachment 9.

Continuing with the example:

$$
\begin{aligned}
& \mathrm{X}_{\mathrm{Gf}}=10,510 / 6000=1.752 \\
& \mathrm{~V}_{\mathrm{GF}}=(0.4099 * 1.752-0.0307) 6000=4125 \mathrm{~L}
\end{aligned}
$$

Determine the batch volume before adjustments are made:

$$
\mathrm{V}_{\mathrm{Batch}}=\mathrm{V}_{\mathrm{EC}}+\mathrm{V}_{\mathrm{GF}}
$$

Equation 24

Condition: If $V_{\text {Batch }}>\left(V_{c v}-V_{H}\right)$, proceed with the following where $V_{c v}$ is the LAW Melter Feed Preparation Vessel's control volume (setpoint). If the condition is not met, no adjustment of the batch is necessary, proceed directly to Section 5.9.

Calculate the coefficient to adjust the batch to the set point.

$$
\mathrm{k}_{\mathrm{cv}}=\left(\mathrm{V}_{\mathrm{cv}}-\mathrm{V}_{\mathrm{H}}\right) / \mathrm{V}_{\text {batch i }}
$$

Equation 25

where: $k_{\mathrm{cv}}$ is the batch adjustment coefficient

$\mathrm{V}_{\mathrm{H}}$ is the tank's heal volume

For the example, lets say that $\mathrm{V}_{\mathrm{cv}}=10,000 \mathrm{~L}$ and $\mathrm{V}_{\mathrm{H}}=2,000 \mathrm{~L}$, then

$$
\begin{aligned}
& \mathrm{B}_{\text {atch }}=\quad 5670 \mathrm{~L}+4125 \mathrm{~L}=9795 \mathrm{~L} \\
& \mathrm{~B}_{\text {atch }} \text { of } 9,795 \mathrm{~L} \text { is }>\left(\mathrm{V}_{\mathrm{cv}}-\mathrm{V}_{\mathrm{H}}\right) \text { which is }(10,000 \mathrm{~L}-2,000 \mathrm{~L}) \text { or } 8,000 \mathrm{~L} \text {; therefore, } \\
& \mathrm{k}_{\mathrm{cv}}=(10,000 \mathrm{~L}-2,000 \mathrm{~L}) / 9,750 \mathrm{~L}=0.8205
\end{aligned}
$$

Adjust the amount of Evaporator Concentrates to be sent to the LAW Melter Feed Preparation Vessel per the following equation:

$$
\begin{aligned}
& \mathrm{V}_{\mathrm{EC}}=\mathrm{k}_{\mathrm{cv}} \mathrm{V}_{\mathrm{pEC}} \text { and } \\
& \mathrm{M}_{\mathrm{EC}}=\mathrm{k}_{\mathrm{cv}} \mathrm{M}_{\mathrm{pEC}}
\end{aligned}
$$$$
\text { Equation } 26
$$

where: $\mathrm{V}_{\mathrm{pEV}}$ and $\mathrm{M}_{\mathrm{pEC}}$ are the preliminary (or previously) calculated Evaporator Concentrates volume and mass calculated. 
$V_{E C}$ and $M_{E C}$ are the actual Evaporator Concentrates volume and mass to be sent to the LAW Melter Feed Preparation Vessel.

For the example, $\mathrm{V}_{\mathrm{EC}}=0.8205(5670 \mathrm{~L})=4652 \mathrm{~L}$.

Adjust the mass of each of the glass formers added per the following equation:

$$
\mathrm{M}_{\mathrm{GFi}}=\mathrm{k}_{\mathrm{cv}} \mathrm{A}_{\mathrm{pGF} i}
$$

where: $A_{\mathrm{pGF}}$ is the preliminary calculated mass for glass former " $i$ "

$\mathrm{M}_{\mathrm{GF} i}$ is the actual mass of glass former " $i$ " to add to the LAW Melter

Feed Preparation Vessel.

" $i$ " is $\mathrm{CaO}, \mathrm{SiO}_{2}, \mathrm{H}_{3} \mathrm{BO}_{3}, \mathrm{Fe}_{2} \mathrm{O}_{3}, \mathrm{Li}_{2} \mathrm{CO}_{3}, \mathrm{ZrO}_{2}, \mathrm{TiO}_{2}, \mathrm{Al}_{2} \mathrm{O}_{3}, \mathrm{ZnO}$, and $\mathrm{MgO}$

For $\mathrm{CaO}$ in the example, $\mathrm{M}_{\mathrm{CaO} i}=0.8205(695 \mathrm{~kg})=570 \mathrm{~kg}$

\subsection{Calculating Glass Former Amounts as Added Minerals}

The model thus far calculated the glass formers as their oxides; however, in reality some glass formers are not added as oxides, they are added as carbonates and silicates. Table 1 below lists the oxides, as presently tracked in G2, with the corresponding minerals in the flowsheet (Reynolds, 2002 \& Johnson, 2001).

Table 1

Glass Former Molecular Weights

\begin{tabular}{|c|c|c|c|}
\hline Glass Oxide & $\frac{\text { Glass Oxide Molecular }}{\text { Weight (MW) }}$ & $\begin{array}{l}\text { Corresponding } \\
\text { Glass Former }\end{array}$ & $\frac{\text { Glass F }}{\text { Weight }}$ \\
\hline $\mathrm{B}_{2} \mathrm{O}_{3}$ & 69.62 & $\mathrm{H}_{3} \mathrm{BO}_{3}$ & 61.84 \\
\hline $\mathrm{CaO}$ & 56.08 & $\mathrm{CaOSiO}_{2}$ & 116.17 \\
\hline $\mathrm{Al}_{2} \mathrm{O}_{3}$ & 101.96 & $\mathrm{Al}_{2} \mathrm{O}_{3} \mathrm{SiO}_{2}$ & 162.05 \\
\hline $\mathrm{Fe}_{2} \mathrm{O}_{3}$ & 159.96 & $\mathrm{Fe}_{2} \mathrm{O}_{3}$ & 159.69 \\
\hline $\mathrm{Li}_{2} \mathrm{O}$ & 29.88 & $\mathrm{Li}_{2} \mathrm{CO}_{3}$ & 73.89 \\
\hline $\mathrm{ZrO}_{2}$ & 123.22 & $\mathrm{ZrO}_{2} \mathrm{SiO}_{2}$ & 183.31 \\
\hline $\mathrm{ZnO}$ & 81.37 & $\mathrm{ZnO}$ & 81.37 \\
\hline $\mathrm{MgO}$ & 40.31 & $\mathrm{MgOSiO}_{2}$ & 100.40 \\
\hline $\mathrm{TiO}_{2}$ & 79.90 & $\mathrm{TiO}_{2}$ & 79.90 \\
\hline $\mathrm{SiO}_{2}$ & 60.09 & $\mathrm{SiO}_{2}$ & 60.09 \\
\hline
\end{tabular}

The mass of each added glass former, as the oxide in the glass, is calculated in the G2 Model. 
Calculate the mass of each glass former which must be added to achieve the corresponding oxide mass in the glass using molecular weights from the table above as follows:

- $\quad \mathrm{A}_{\mathrm{H} 3 \mathrm{BO} 3}$ (Previously calculated)

- $\mathrm{A}_{\mathrm{CaOSiO} 2}=\mathrm{A}_{\mathrm{CaO}} *\left(\mathrm{MW}_{\mathrm{CaOSiO} 2} / \mathrm{MW}_{\mathrm{CaO}}\right)$

- $\mathrm{A}_{\mathrm{Al} 2 \mathrm{O} 3 \mathrm{SiO} 2}=\mathrm{A}_{\mathrm{Al} 2 \mathrm{O} 3} *\left(\mathrm{MW}_{\mathrm{Al} 2 \mathrm{O} 3 \mathrm{SiO} 2} / \mathrm{MW}_{\mathrm{Al} 2 \mathrm{O} 3}\right)$
- $\mathrm{A}_{\mathrm{Li2CO3}}$ (Previously calculated)

- $\mathrm{A}_{\mathrm{ZrO} 2 \mathrm{SiO} 2}=\mathrm{A}_{\mathrm{ZrO} 2} *\left(\mathrm{MW}_{\mathrm{ZrO} 2 \mathrm{SiO} 2} / \mathrm{MW}_{\mathrm{ZrO} 2}\right)$

- $\mathrm{A}_{\mathrm{MgOSiO} 2}=\mathrm{A}_{\mathrm{MgO}} *\left(\mathrm{MW}_{\mathrm{MgOSiO} 2} / \mathrm{MW}_{\mathrm{MgO}}\right)$

The glass former mass of $\mathrm{Fe}_{2} \mathrm{O}_{3}\left(\mathrm{~A}_{\mathrm{Fe} 2 \mathrm{O} 3}\right), \mathrm{ZnO}\left(\mathrm{A}_{\mathrm{ZnO}}\right)$ and $\mathrm{TiO}_{2}\left(\mathrm{~A}_{\mathrm{TiO} 2}\right)$, which must be added to achieve the corresponding oxide mass in the glass, is the same as the mass in the glass since these components are already oxides.

The mass of $\mathrm{SiO}_{2}\left(\mathrm{~A}_{\mathrm{SiO2}-\mathrm{GF}}\right)$ which must be added as a glass former is calculated by subtracting from $\mathrm{A}_{\mathrm{SiO} 2}$ the mass contributions of $\mathrm{SiO}_{2}$ from $\mathrm{CaOSiO}_{2}, \mathrm{Al}_{2} \mathrm{O}_{3} \mathrm{SiO}_{2}, \mathrm{ZrO}_{2} \mathrm{SiO}_{2}$, and $\mathrm{MgOSiO}_{2}$.

First calculate the mass of $\mathrm{SiO}_{2}$ associated with $\mathrm{CaOSiO}, \mathrm{Al}_{2} \mathrm{O}_{3} \mathrm{SiO}_{2}, \mathrm{ZrO}_{2} \mathrm{SiO}_{2}$, and $\mathrm{MgOSiO}_{2}$ :

- $\mathrm{MSiO}_{2-\mathrm{CaO}}=\mathrm{A}_{\mathrm{CaOSiO} 2} *\left(\mathrm{MW}_{\mathrm{SiO} 2} / \mathrm{MW}_{\mathrm{CaOSiO} 2}\right)$

- $\mathrm{MSiO}_{2-\mathrm{Al} 2 \mathrm{O} 3}=\mathrm{A}_{\mathrm{Al} 2 \mathrm{O} 3 \mathrm{SiO} 2} *\left(\mathrm{MW}_{\mathrm{SiO} 2} / \mathrm{MW}_{\mathrm{Al2O} 3 \mathrm{SiO} 2}\right)$

- $\mathrm{MSiO}_{2-\mathrm{ZrO} 2}=\mathrm{A}_{\mathrm{ZrO} 2 \mathrm{SiO} 2} *\left(\mathrm{MW}_{\mathrm{SiO} 2} / \mathrm{MW}_{\mathrm{ZrO} 2 \mathrm{SiO} 2}\right)$

- $\mathrm{MSiO}_{2-\mathrm{MgO}}=\mathrm{A}_{\mathrm{MgOSiO} 2}{ }^{*}\left(\mathrm{MW}_{\mathrm{SiO} 2} / \mathrm{MW}_{\mathrm{MgOSiO} 2}\right)$

Then subtract the contributions from $\mathrm{M}_{\mathrm{SiO}}$, the total mass of $\mathrm{SiO}_{2}$ needed to obtain the mass of $\mathrm{SiO}_{2}$ added as a glass former:

- $\quad \mathrm{A}_{\mathrm{SiO2-GF}}=\mathrm{ASiO}_{2}-\left(\mathrm{MSiO}_{2-\mathrm{CaO}}+\mathrm{MSiO}_{2-\mathrm{Al203}}+\mathrm{MSiO}_{2-\mathrm{Z} \mathrm{FO}}+\mathrm{MSiO}_{2-\mathrm{MgO}}\right)$

Where: $\mathrm{A}_{\mathrm{SiO} 2-\mathrm{GF}}$ is the mass of $\mathrm{SiO}_{2}$ added as a glass former.

Determine the bulk volume of each glass former mineral by dividing each mineral's mass by its corresponding density taken from Table 2. Densities come from Johnson (2001). Note that the density values may need to be converted depending on units used in the model.

Table 2

Bulk Density of Minerals used for Glass Formers

Glass Former/

$\underline{\text { Mineral }}$

$\mathrm{H}_{3} \mathrm{BO}_{3}$

$\mathrm{CaOSiO}_{2}$

$\mathrm{Al}_{2} \mathrm{O}_{3} \mathrm{SiO}_{2}$

$\mathrm{Fe}_{2} \mathrm{O}_{3}$

$\mathrm{Li}_{2} \mathrm{CO}_{3}$

$\mathrm{ZrO}_{2} \mathrm{SiO}_{2}$

$\mathrm{ZnO}$

$\mathrm{MgOSiO}_{2}$

$\mathrm{TiO}_{2}$

$\mathrm{SiO}_{2}$

\section{Common Name}

Boric acid

Wollastonite, calcium silicate

Kyanite, aluminum silicate

Ferric oxide

Lithium carbonate

Zircon sand, zirconium silicate

Zinc oxide

Olivine, magnesium Silicate

Rutile, Titanium dioxide

Sand, silica, silicon dioxide
Bulk Density, $\mathrm{kg} / \mathrm{m}^{3}$

910

730

1050

2150

920

1650

660

1550

650

920 


\section{Conclusions}

The LAW glass formulations, developed by VSL, follow a trend that can be plotted and glass constituents and their concentrations can be calculated. This was incorporated into the model presented in this paper. This model then can be used to calculate glass former amounts needed in the G2 and ACM models.

\section{References}

I. S. Muller and I. L. Pegg, Vitreous State Laboratory (VSL) Report Document No. 24590-LAW-TP- RT-01-010, LAW Glass Formulation to Support Actual Waste Testing Test Plan, Rev. 0, Vitreous State Laboratory, The Catholic University of America, Washington D.C.

I. S. Muller, Andrew C. Buechele and I. L. Pegg, February 23, 2001, Vitreous State Laboratory (VSL) report Document No. VSL-01R3560-2, Glass Formulation and Testing with RPP-WTP LAW Simulants, Vitreous State Laboratory, The Catholic University of America, Washington D.C.

Pegg, I. L. et al., 2000. Interim Report: Summary of Preliminary Results on Enhanced Sulfate Incorporation During Vitrification of LAW Feeds. VSL-00R3630-1. Vitreous State Laboratory, Catholic University of America, Washington, D.C.

VSL 2000, Duramelter 100 LAW Subenvelope C1 Variation Tests, Test Plan VSL-01T62N0-2, The Catholic University of America, Vitreous State Laboratory.

Johnson, P., 2001, LAW Blended Glass Former Average Densities, CALC-W375LV-PR00055, Rev. 1. Bechtel National, Inc., Richland, Washington.

Reynolds, J. R., 2002, Calculation of Oxide Density of Some Glass Former Batches for LAW, 24590-LAW-M4CLFP-00003, Rev. B, Bechtel National, Inc., Richland, Washington.

\section{Attachments}

The attachments addressed in this document follow. 


\section{CALCULATION SHEET}

BY: Rod Gimpel

DATE: 05/30/02

SUBJECT: Determining the LAW Glass Former Constituents and Amounts for G2 and ACM Models
ORP-56511, Rev. B

PROJECT: RPP-WTP JOB NO.: 24590

CALC NO.:24590-LAW-M4C-LFP-00002

SHEET REV: B

SHEET NO.: 12

\section{Attachment 1 \\ Excerpt from:}

I. S. Muller and I. L. Pegg, Vitreous State Laboratory (VSL) report Document No. 24590-LAW-TPRT-01-010, LAW Glass Formulation to Support Actual Waste Testing Test Plan, Rev. 0, Vitreous State Laboratory, The Catholic University of America, Washington D.C.

(One page) 


\section{CALCULATION SHEET}

BY: Rod Gimpel

DATE: 05/30/02

SUBJECT: Determining the LAW Glass Former Constituents and Amounts for G2 and ACM Models
ORP-56511, Rev. B

PROJECT: RPP-WTP

JOB NO.: 24590

CALC NO.:24590-LAW-M4C-LFP-00002

SHEET REV: $B$

SHEET NO.: 13

Table 3.1

Glass Compositions Selected in Part B1.

\begin{tabular}{|c|c|c|c|c|c|c|c|}
\hline GLASS & LAWA44 & LAWA88 & LAWA102 & LAWB45 & LAWB53 & LAWC21 & LAWC22 \\
\hline $\begin{array}{l}\text { Tank ID } \\
\text { (based on case } 3 \mathrm{~S} 6 \mathrm{E} \text { ) }\end{array}$ & $\begin{array}{l}\text { AN-105 } \\
\text { SY-101 } \\
\text { AN-103 }\end{array}$ & $\begin{array}{l}A P-101 \\
A W-101\end{array}$ & $\begin{array}{l}\text { AN-104 } \\
\text { AW-104 }\end{array}$ & $\mathrm{AZ}-102$ & AZ-101 & AN-102 & AN-107 \\
\hline $\begin{array}{l}\text { Typical waste } \\
\text { Loading }\end{array}$ & $26 \%$ & $26 \%$ & $18 \%$ & $9 \%$ & $6 \%$ & $14 \%$ & $16 \%$ \\
\hline $\mathrm{Al} 2 \mathrm{O} 3$ & 6.201 & 6.080 & 6.054 & 6.129 & 6.099 & 6.125 & 6.080 \\
\hline $\mathrm{B} 2 \mathrm{O} 3$ & 8.902 & 9.698 & 9.995 & 12.340 & 10.026 & 10.088 & 10.068 \\
\hline $\mathrm{BaO}$ & 0.000 & 0.000 & 0.001 & 0.000 & 0.000 & 0.000 & 0.000 \\
\hline $\mathrm{CaO}$ & 1.994 & 1.991 & 5.065 & 6.627 & 6.746 & 6.409 & 5.117 \\
\hline $\mathrm{Cl}$ & 0.652 & 0.329 & 0.333 & 0.006 & 0.005 & 0.124 & 0.090 \\
\hline $\mathrm{Cr} 2 \mathrm{O} 3$ & 0.020 & 0.009 & 0.018 & 0.073 & 0.113 & 0.020 & 0.021 \\
\hline $\mathrm{Cs} 2 \mathrm{O}$ & 0.001 & 0.001 & 0.001 & 0.002 & 0.000 & 0.000 & 0.001 \\
\hline $\mathrm{F}$ & 0.010 & 0.000 & 0.025 & 0.081 & 0.063 & 0.060 & 0.162 \\
\hline $\mathrm{Fe} 2 \mathrm{O} 3$ & 6.981 & 5.531 & 5.407 & 5.256 & 5.341 & 6.477 & 5.431 \\
\hline $\mathrm{K} 2 \mathrm{O}$ & 0.501 & 2.583 & 0.260 & 0.262 & 0.227 & 0.151 & 0.095 \\
\hline $\mathrm{Li} 2 \mathrm{O}$ & 0.000 & 0.000 & 2.499 & 4.616 & 5.856 & 2.733 & 2.505 \\
\hline $\mathrm{MgO}$ & 1.994 & 1.475 & 1.494 & 2.971 & 2.998 & 1.509 & 1.513 \\
\hline $\mathrm{MnO} 2$ & 0.000 & 0.000 & 0.000 & 0.000 & 0.000 & 0.004 & 0.037 \\
\hline $\mathrm{MoO} 3$ & 0.000 & 0.000 & 0.000 & 0.000 & 0.005 & 0.000 & 0.000 \\
\hline $\mathrm{Na} 2 \mathrm{O}$ & 20.000 & 20.000 & 14.478 & 6.500 & 5.000 & 11.871 & 14.400 \\
\hline $\mathrm{NiO}$ & 0.000 & 0.000 & 0.000 & 0.000 & 0.000 & 0.000 & 0.030 \\
\hline $\mathrm{PbO}$ & 0.001 & 0.000 & 0.000 & 0.000 & 0.000 & 0.000 & 0.021 \\
\hline \begin{tabular}{|l|}
$\mathrm{P} 2 \mathrm{O} 5$ \\
\end{tabular} & 0.034 & 0.070 & 0.133 & 0.030 & 0.013 & 0.118 & 0.174 \\
\hline $\mathrm{SiO} 2$ & 44.553 & 43.991 & 46.569 & 47.859 & 48.924 & 46.727 & 46.667 \\
\hline $\mathrm{SO} 3$ & 0.095 & 0.214 & 0.441 & 0.844 & 0.807 & 0.424 & 0.341 \\
\hline $\mathrm{SrO}$ & 0.0000 & 0.0000 & 0.000 & 0.000 & 0.000 & 0.000 & 0.000 \\
\hline $\mathrm{TiO} 2$ & 1.994 & 1.991 & 1.143 & 0.000 & 1.405 & 1.121 & 1.143 \\
\hline $\mathrm{UO} 2$ & 0.000 & 0.000 & 0.000 & 0.000 & 0.000 & 0.000 & 0.004 \\
\hline $\mathrm{ZnO}$ & 2.965 & 2.950 & 3.062 & 3.153 & 3.186 & 3.018 & 3.069 \\
\hline $\mathrm{ZrO} 2$ & 2.992 & 2.987 & 3.022 & 3.153 & 3.186 & 3.021 & 3.027 \\
\hline SUM & 100.000 & 100.000 & 100.000 & 100.000 & 100.000 & 100.000 & 100.000 \\
\hline
\end{tabular}




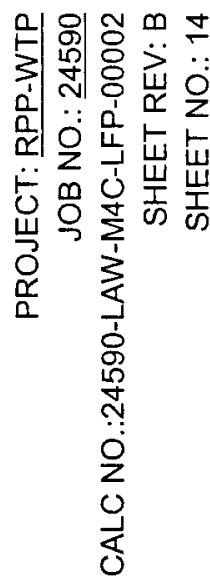

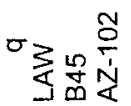

a $\frac{5}{5}$

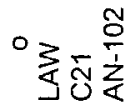

$=3 ญ \frac{\hat{O}}{5}$

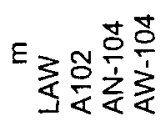

$-3 \infty \frac{5}{5} \frac{5}{4}$

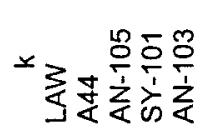

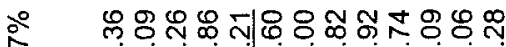

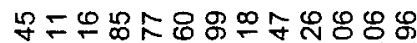

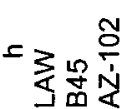

ฉั

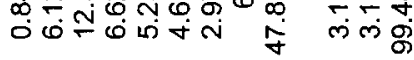

웅

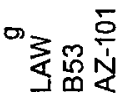

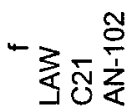

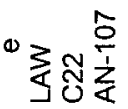

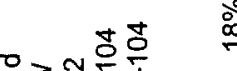

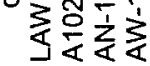

৩

离

$$
\stackrel{2}{\stackrel{0}{+}}
$$

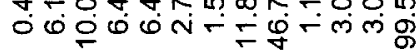

$\stackrel{\circ}{\circ}$

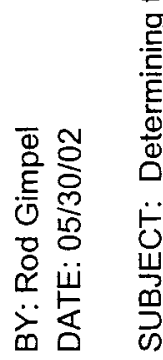

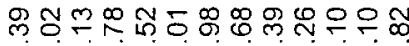

OOO O

ஸि

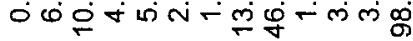

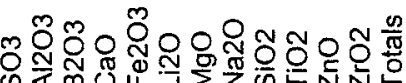
U⿺辶巛

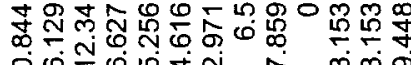

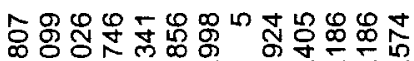

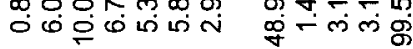

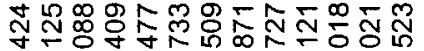

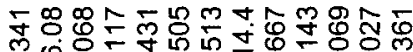

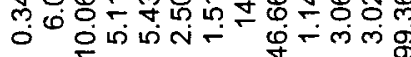

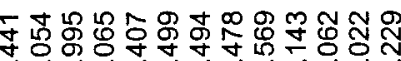

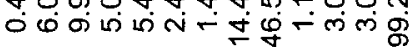

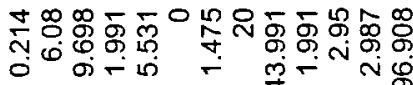

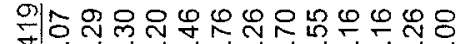

क्णी:

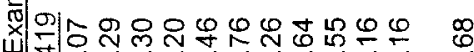

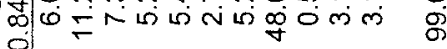

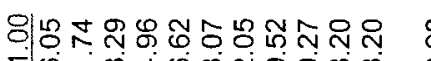
- $=\infty$ पं

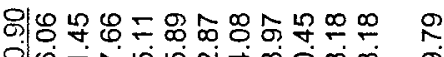

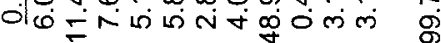

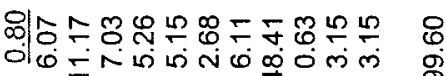

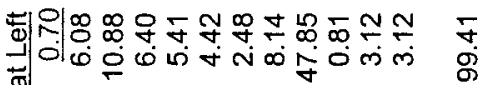

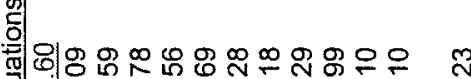

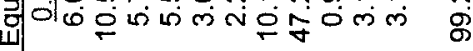

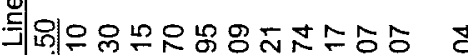

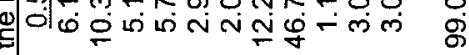

일윋ํำ

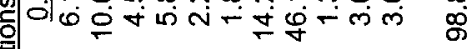

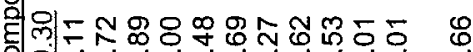

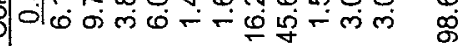

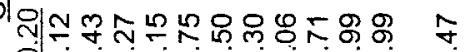

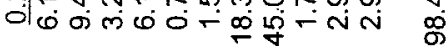

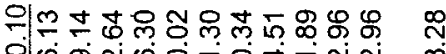
कंषें

$\begin{array}{ll}11 & 11 \\ 0 & 0\end{array}$

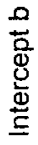

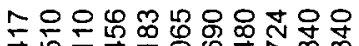

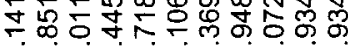

ตั

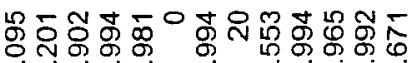

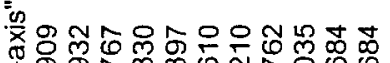

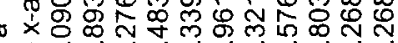

范 1 ị 음 뜯

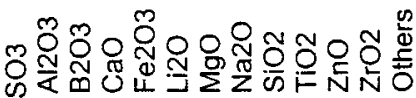




\title{
Attachment 2 (Continued) \\ Variability in LAW Glass Recipes Determination Spreadsheet -- Elements as Oxides Formula Displayed Spreadsheet Format
}

\author{
Spreadsheet's Sheet Name: GF as Oxides
}

(Four pages) 
BY: Rod Gimpel

CALC NO.:24590-LAW-M4C-LFP-00002

DATE: 05/30/02

SHEET REV: $B$

SUBJECT: Determining the LAW Glass Former Constituents and Amounts for G2 and ACM Models

SHEET NO.: 16

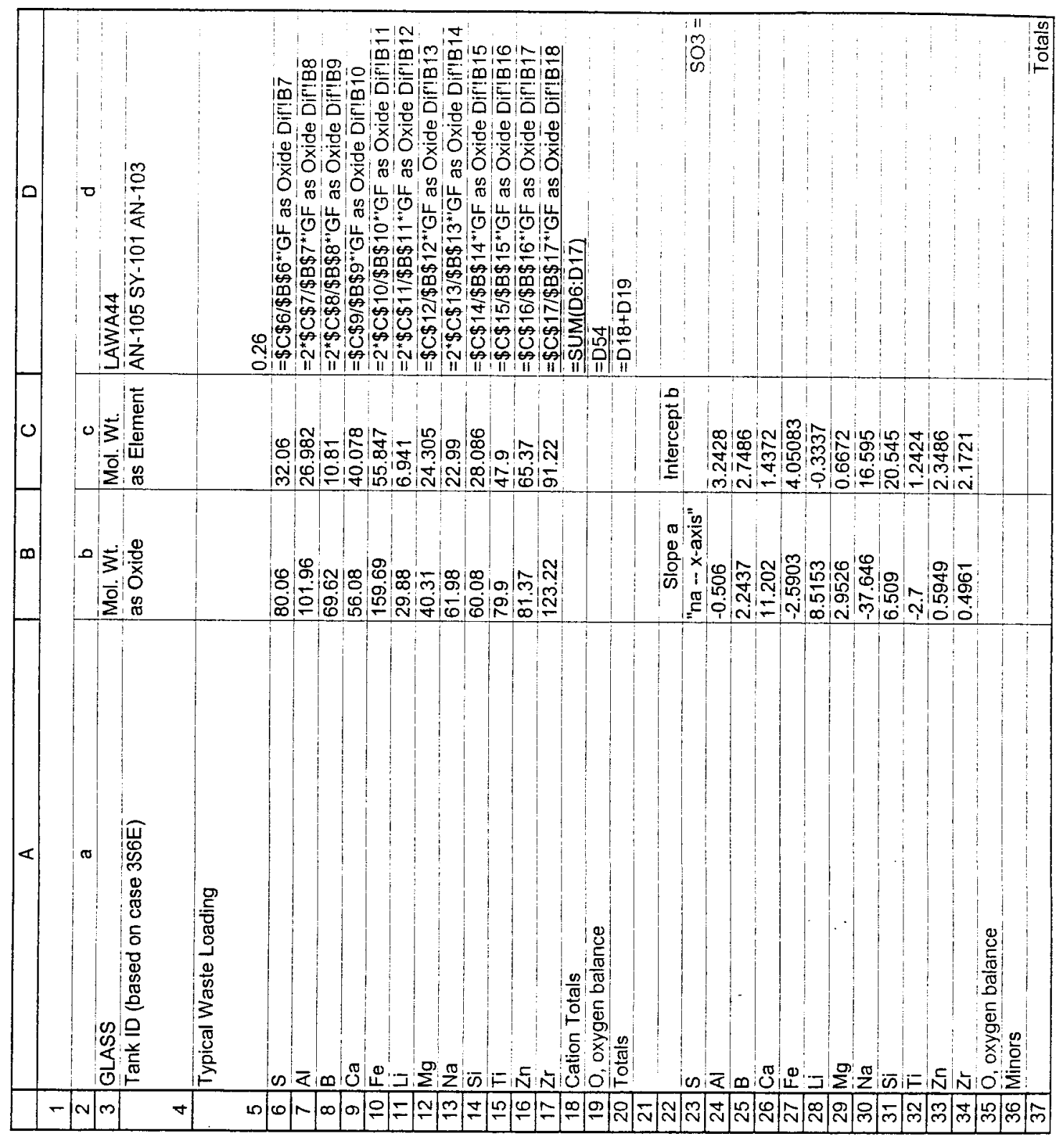


BY: Rod Gimpe!

DATE: 05/30/02

SHEET REV: B

SHEET NO:: 17

SUBJECT: Determining the LAW Glass Former Constituents and Amounts for G2 and ACM Models

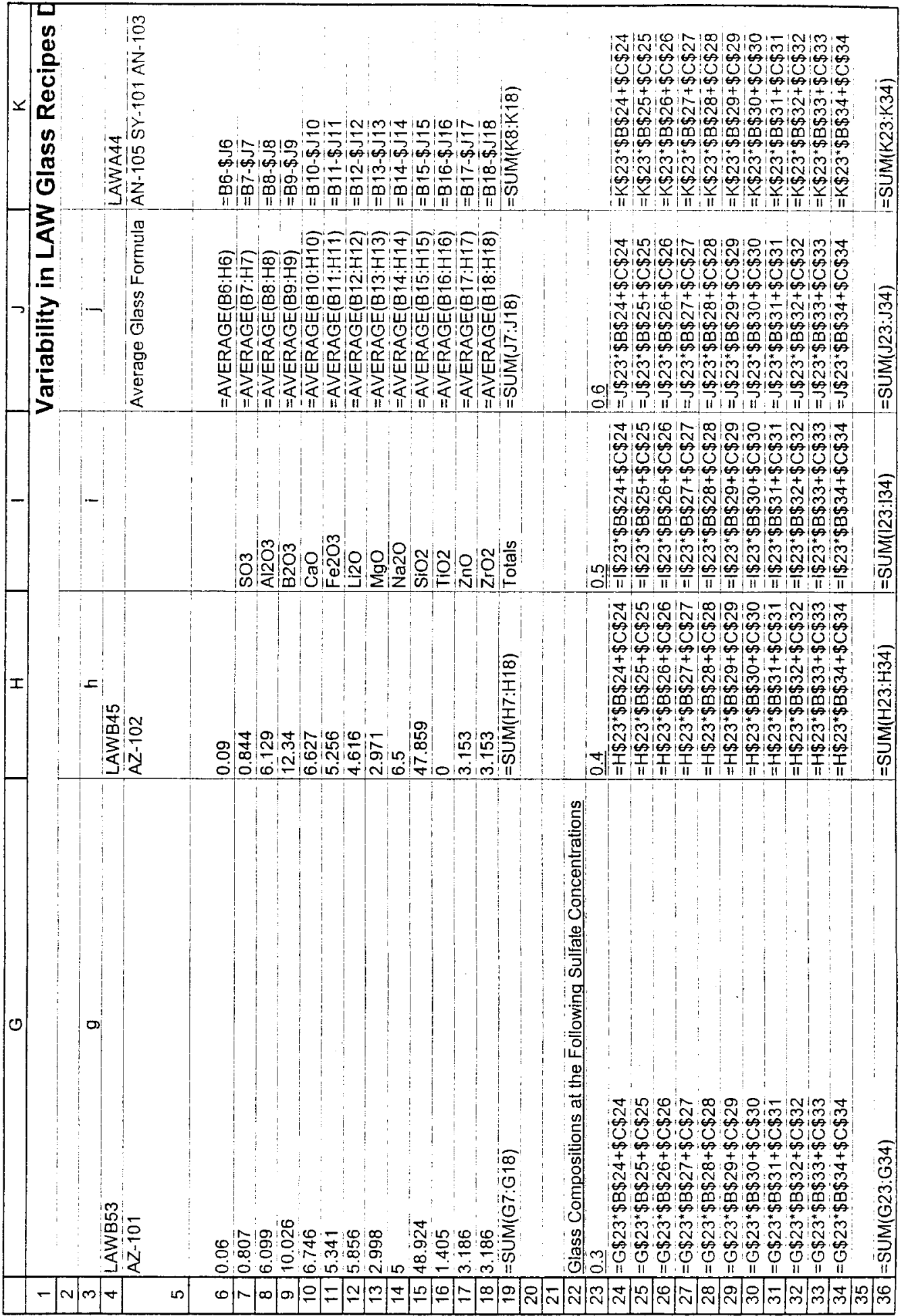


BY: Rod Gimpel

DATE: 05/30/02

SHEET REV: $B$

SHEET NO: 18

SUBJECT: Determining the LAW Glass Former Constituents and Amounts for G2 and ACM Models

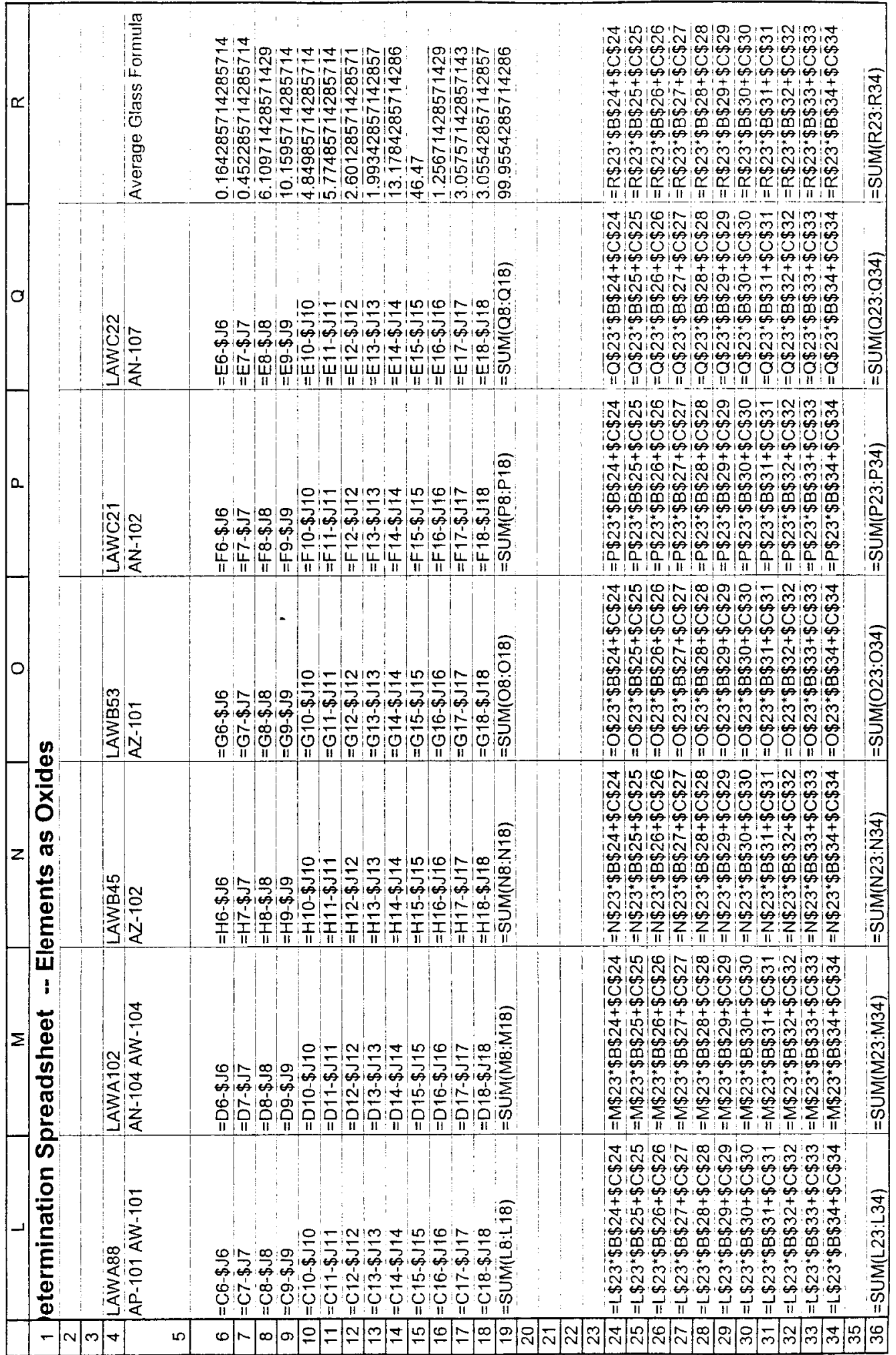


$B Y:$ Rod Gimpel

DATE: 05/30/02

SUBJECT: Determining the LAW Glass Former Constituents and Amounts for G2 and ACM Models

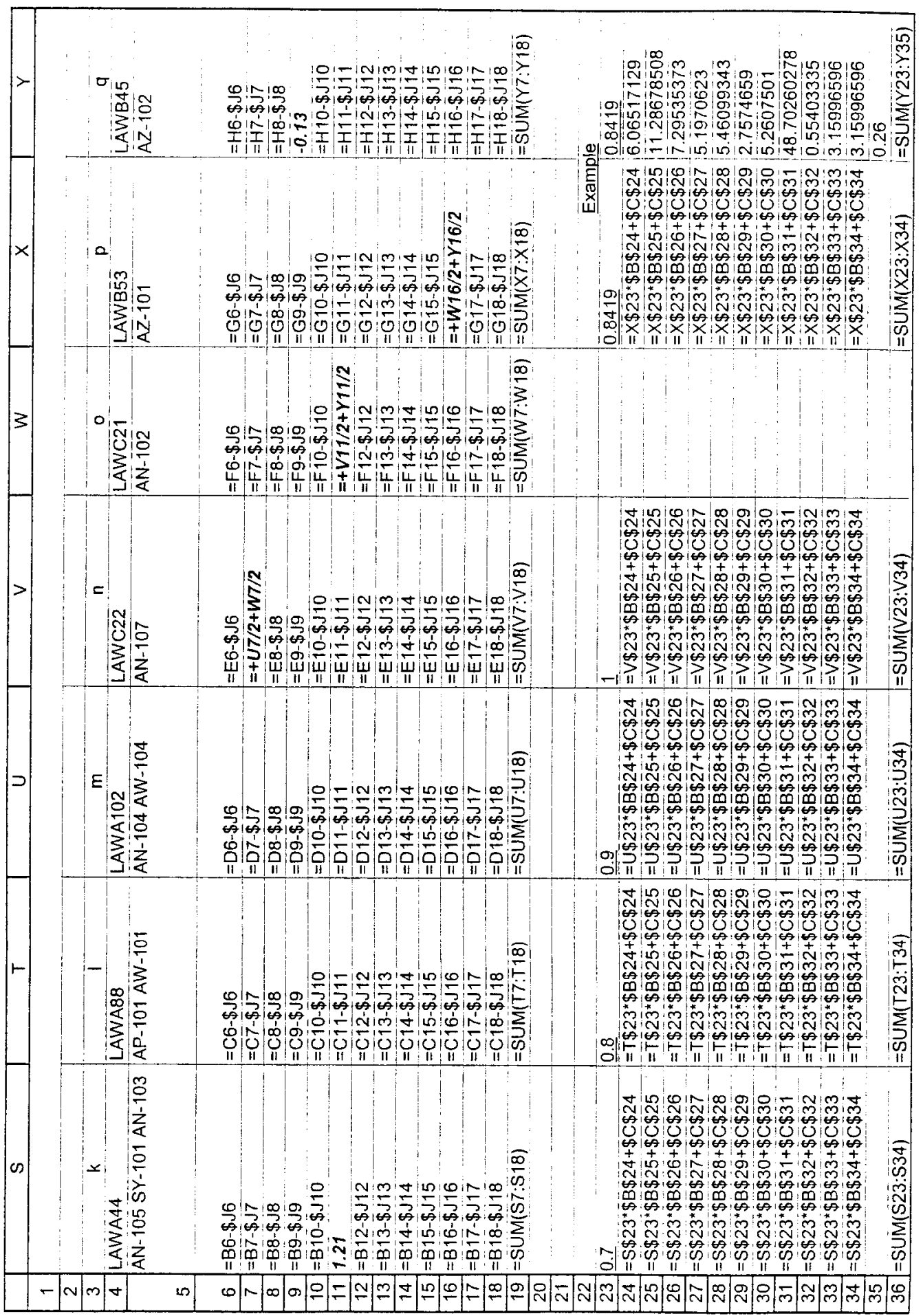




\section{CALCULATION SHEET}

BY: Rod Gimpel

DATE: 05/30/02

SUBJECT: Determining the LAW Glass Former Constituents and Amounts for G2 and ACM Models
PROJECT: RPP-WTP JOB NO.: $\underline{24590}$ CALC NO.:24590-LAW-M4C-LFP-00002 SHEET REV: B SHEET NO.: $\underline{20}$

\section{Attachment 3}

\section{Law Glass Oxide vs. $\mathrm{SO}_{3}$ - Differences from Average Glass Composition Plot}

(One Page) 
BY: Rod Gimpel CALC NO.:24590-LAW-M4C-LFP-00002

DATE: 05/30/02

SHEET REV: B

SUBJECT: Determining the LAW Glass Former Constituents and Amounts for G2 and ACM Models

SHEET NO.: 21

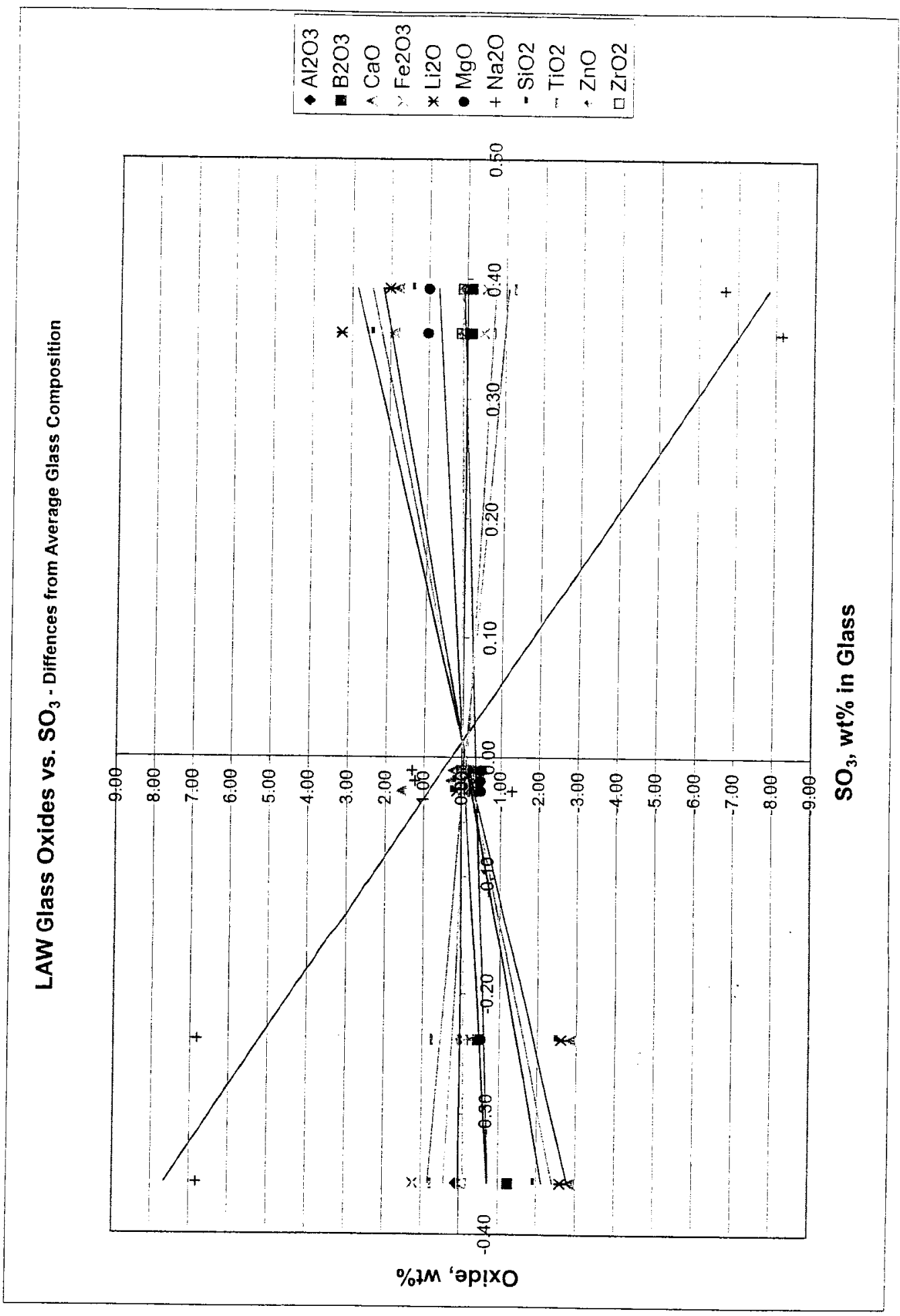




\section{Attachment 4}

\section{Law Glass Oxides vs. $\mathrm{So}_{3}$ Plot}

(11 pages)

Page 1

Page 2

Page 3

Page 4

Page 5

Page 6

Page 7

Page 8

Page 9

Page 10

Page 11
Combined Plot

$\mathrm{SiO}_{2}$ Plot

$\mathrm{Na}_{2} \mathrm{O}$ Plot

$\mathrm{B}_{2} \mathrm{O}_{3}$ Plot

$\mathrm{CaO}$ Plot

$\mathrm{Al}_{2} \mathrm{O}_{3}$ Plot

$\mathrm{Fe}_{2} \mathrm{O}_{3}$ Plot

$\mathrm{Li}_{2} \mathrm{O}$ Plot

$\mathrm{ZrO}_{2} \& \mathrm{ZnO}$ Plot

MgO Plot

$\mathrm{TiO}_{2}$ Plot 
BY: Rod Gimpel

DATE: 05/30/02

SUBJECT: Determining the LAW Glass Former Constituents and Amounts for G2 and ACM Models

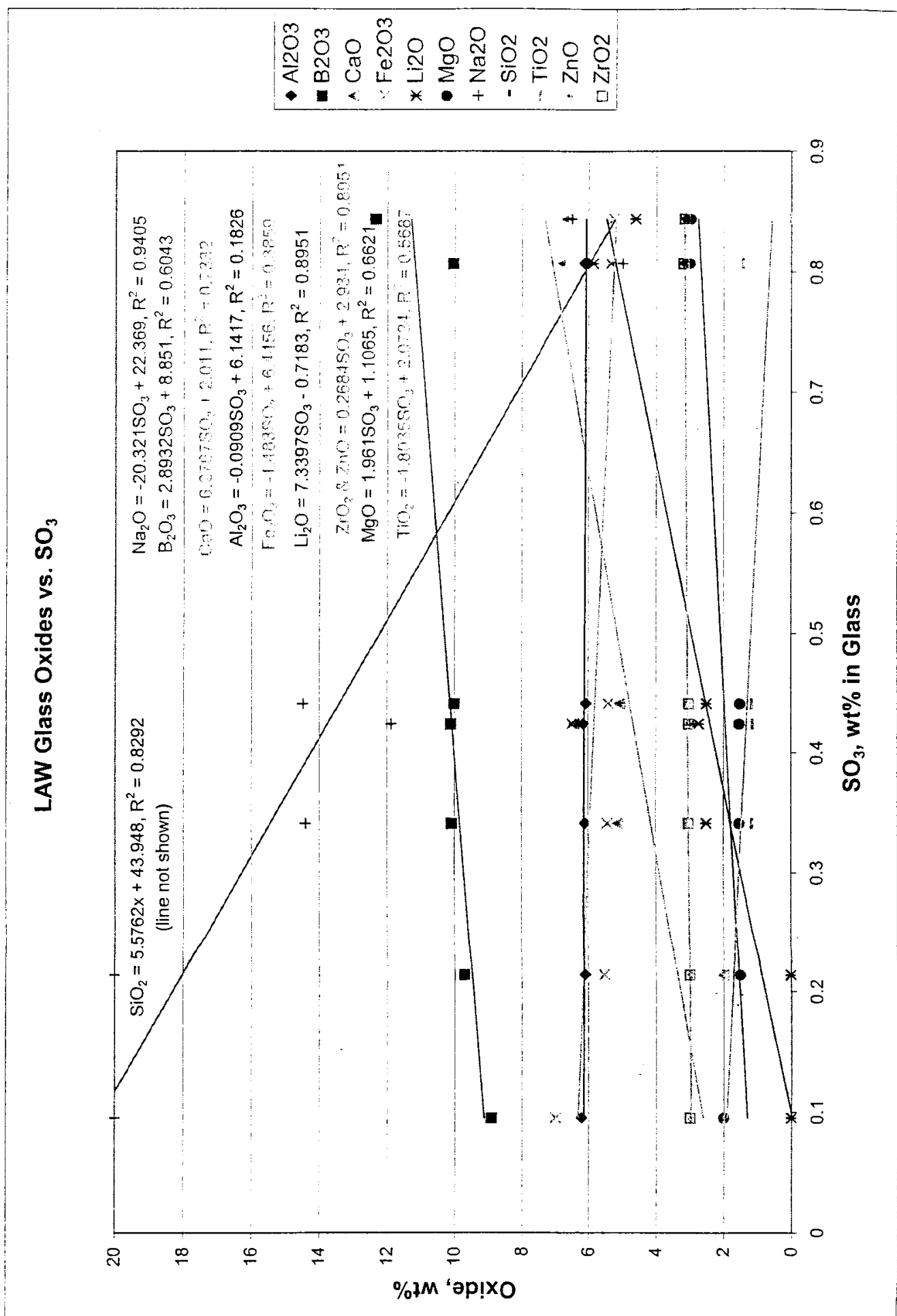


BY: Rod Gimpel CALC NO.:24590-LAW-M4C-LFP-00002

DATE: 05/30/02 SHEET REV: $B$

SHEET NO.: 24

SUBJECT: Determining the LAW Glass Former Constituents and Amounts for G2 and ACM Models

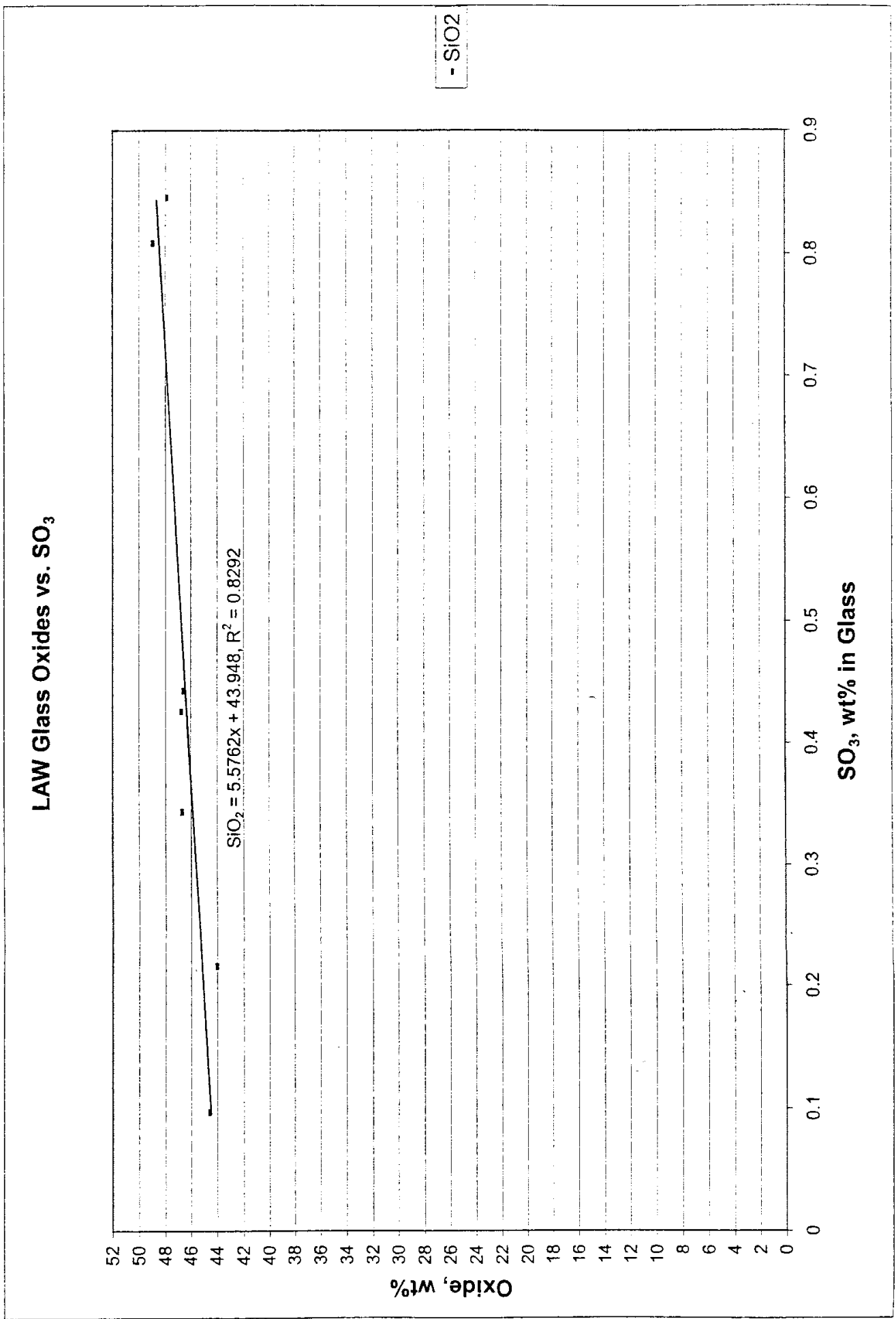


BY: Rod Gimpel CALC NO.:24590-LAW-M4C-LFP-00002

DATE: 05/30/02

SUBJECT: Determining the LAW Glass Former Constituents and Amounts for G2 and ACM Models

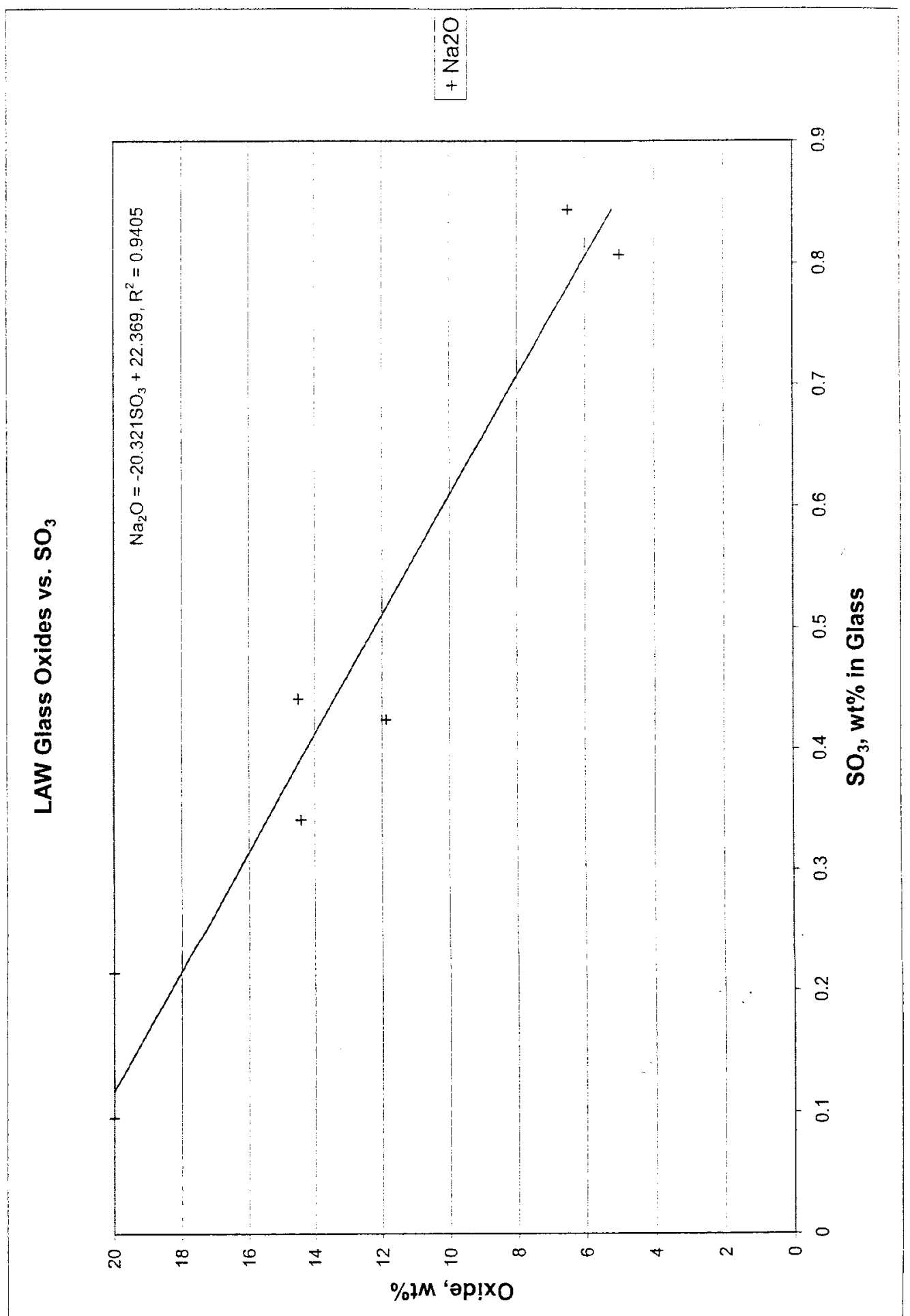


BY: Rod Gimpe|

SUBJECT: Determining the LAW Glass Former Constituents and Amounts for G2 and ACM Models

SHEET NO.: $\underline{20}$

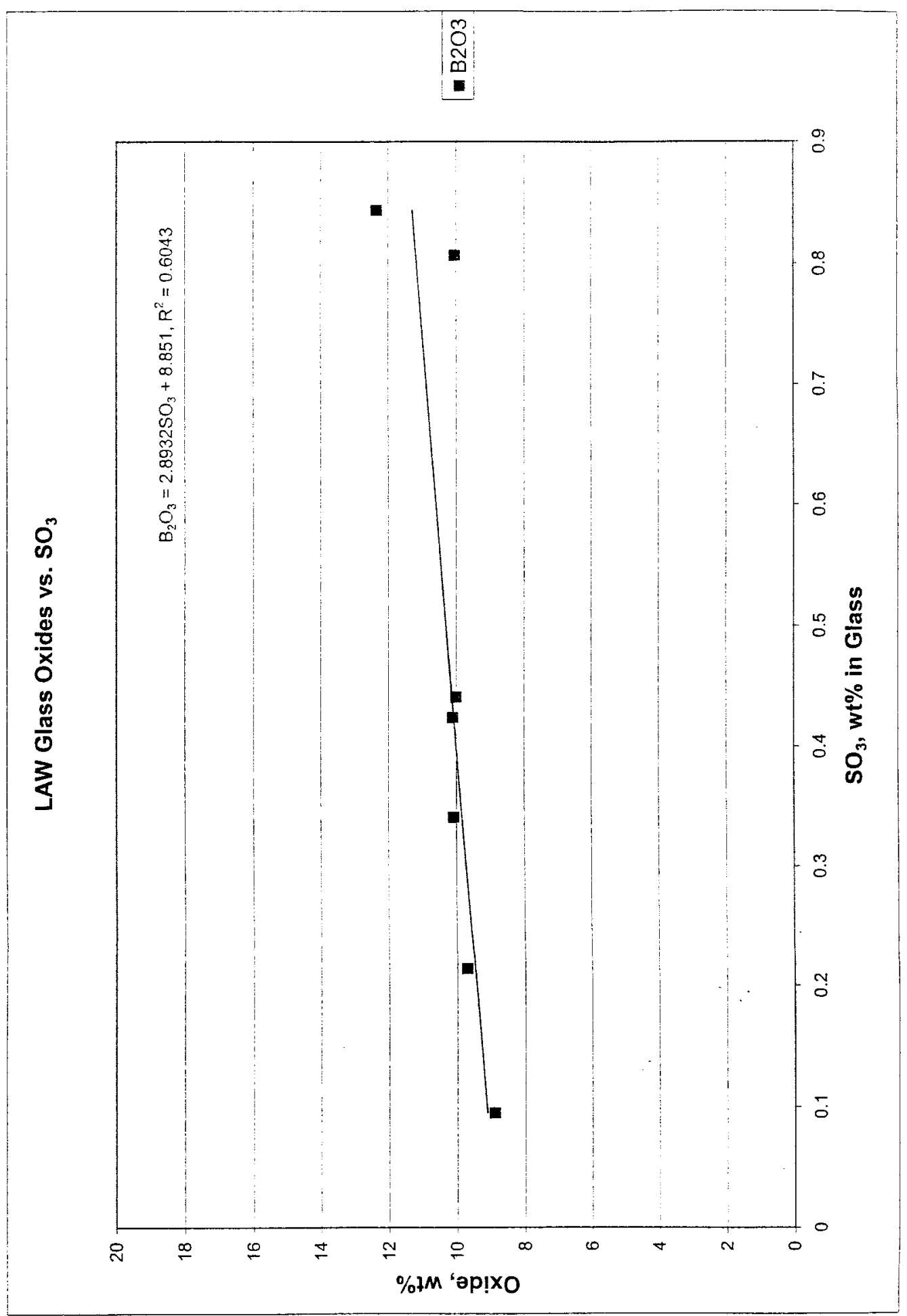


BY: Rod Gimpel

DATE: 05/30/02

SHEET REV: $B$

SHEET NO.: 27

SUBJECT: Determining the LAW Glass Former Constituents and Amounts for G2 and ACM Models

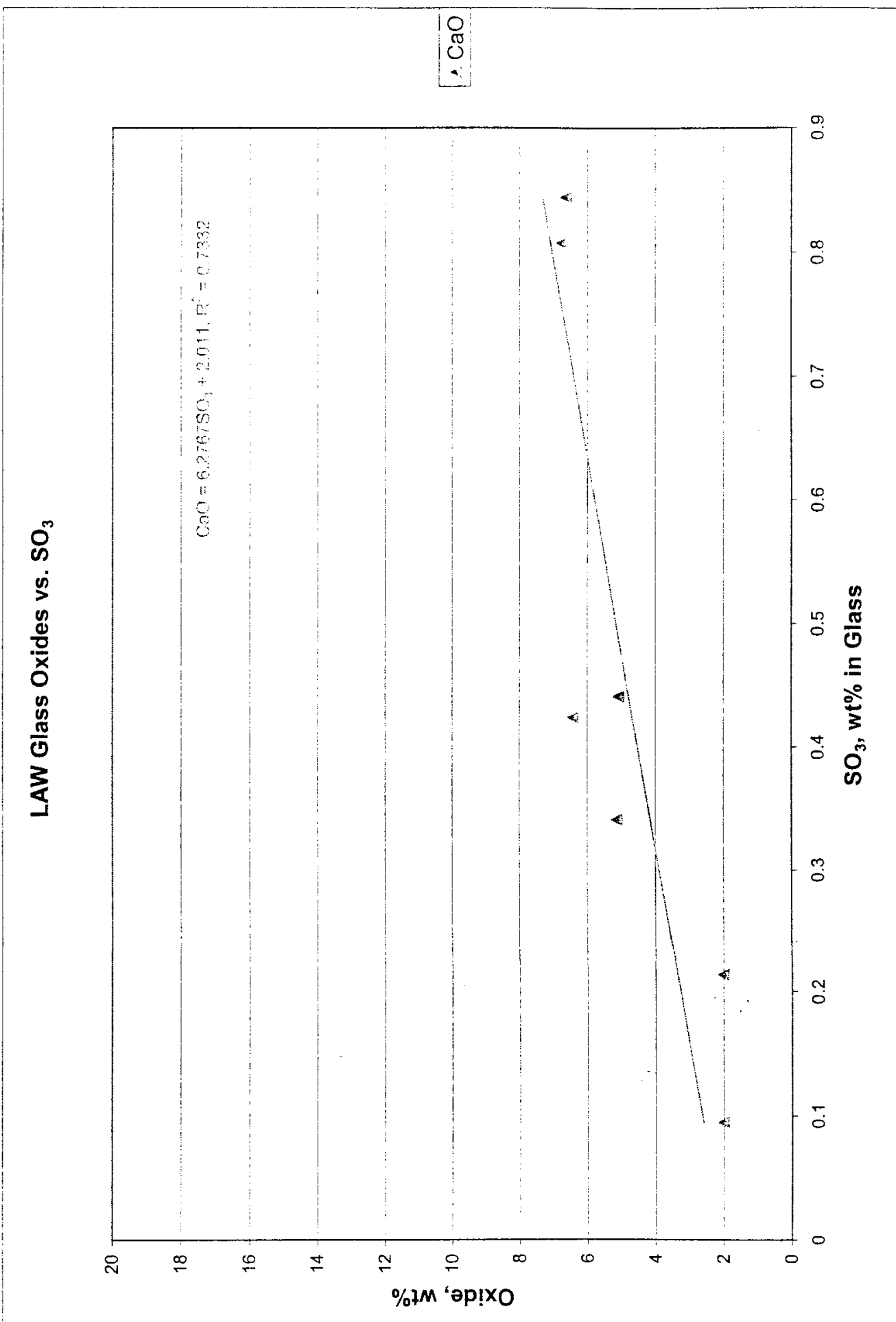


SUBJECT: Determining the LAW Glass Former Constituents and Amounts for G2 and ACM Models

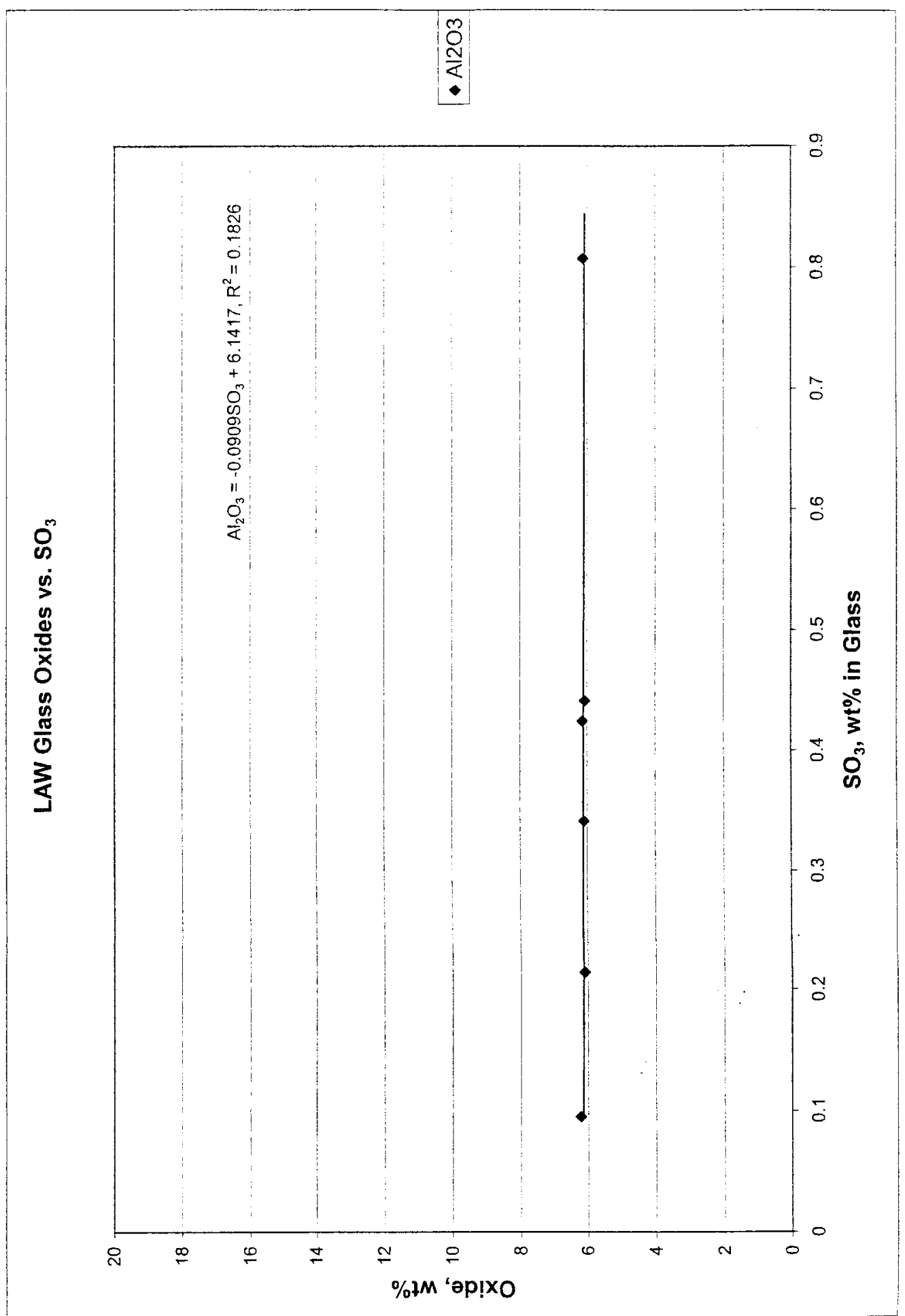


BY: Rod Gimpel

CALC NO.:24590-LAW-M4C-LFP-00002

DATE: 05/30/02

SHEET REV: B

SUBJECT: Determining the LAW Glass Former Constituents and Amounts for G2 and ACM Models

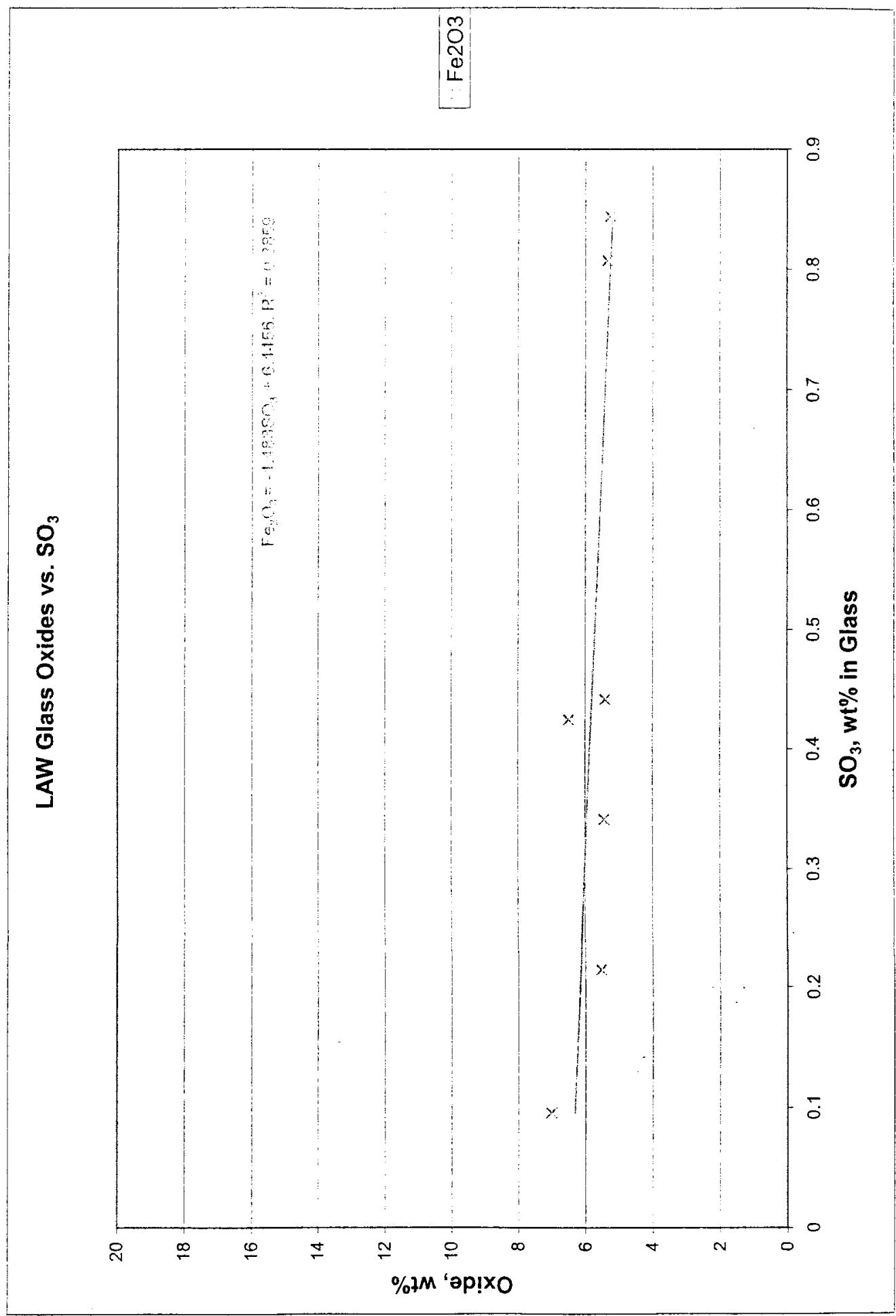


BY: Rod Gimpel

CALC NO.:24590-LAW-M4C-LFP-00002

DATE: 05/30/02

SHEET REV: $B$

SUBJECT: Determining the LAW Glass Former Constituents and Amounts for G2 and ACM Models

SHEET NO: 30

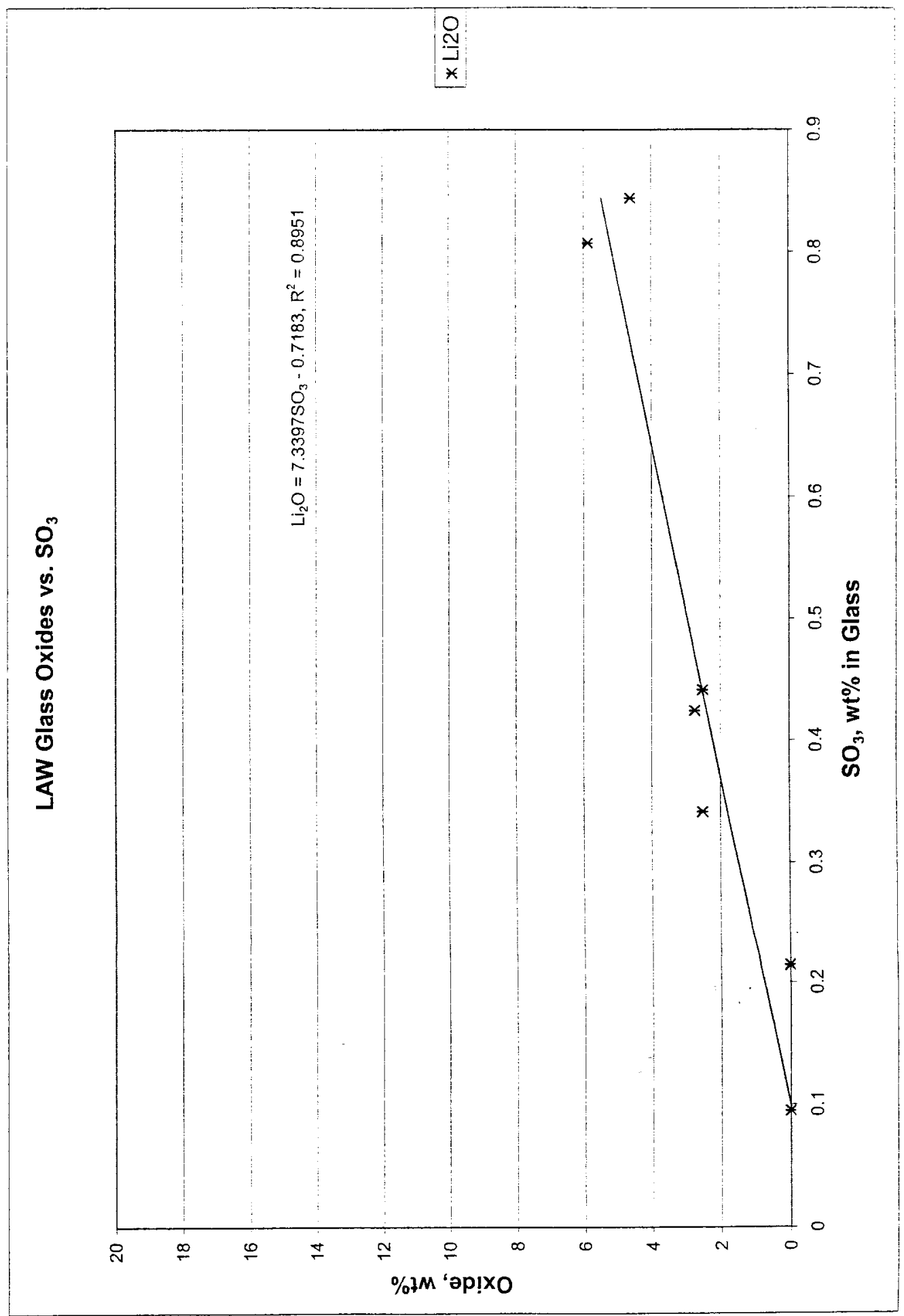


BY: Rod Gimpel

CALC NO.:24590-LAW-M4C-LFP-00002

DATE: 05/30/02

SHEET REV: $B$

SUBJECT: Determining the LAW Glass Former Constituents and Amounts for G2 and ACM Models

SHEET NO: 31

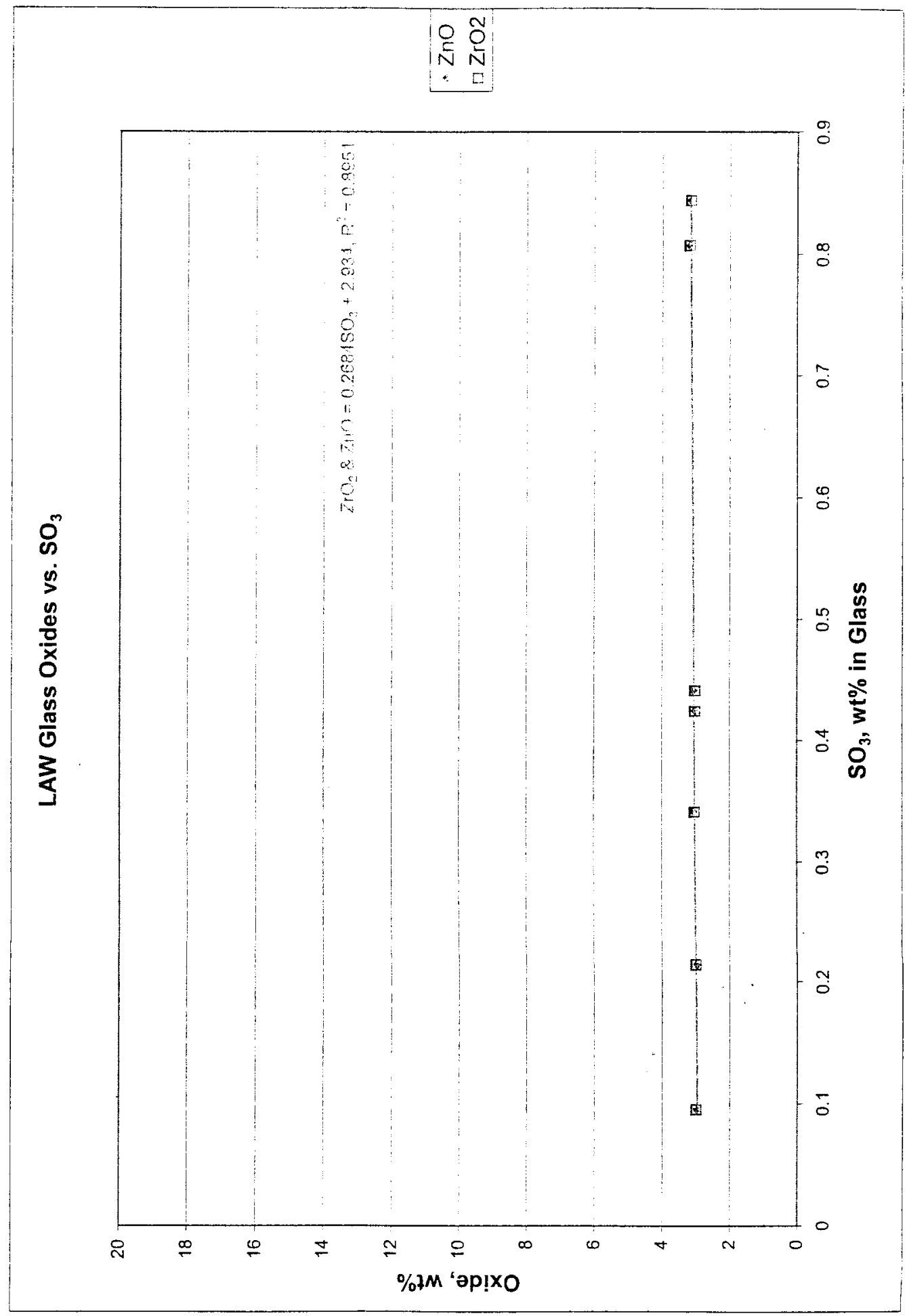


BY: Rod Gimpel

DATE: 05/30/02

SUBJECT: Determining the LAW Glass Former Constituents and Amounts for G2 and ACM Models

SHEET NO.: 32

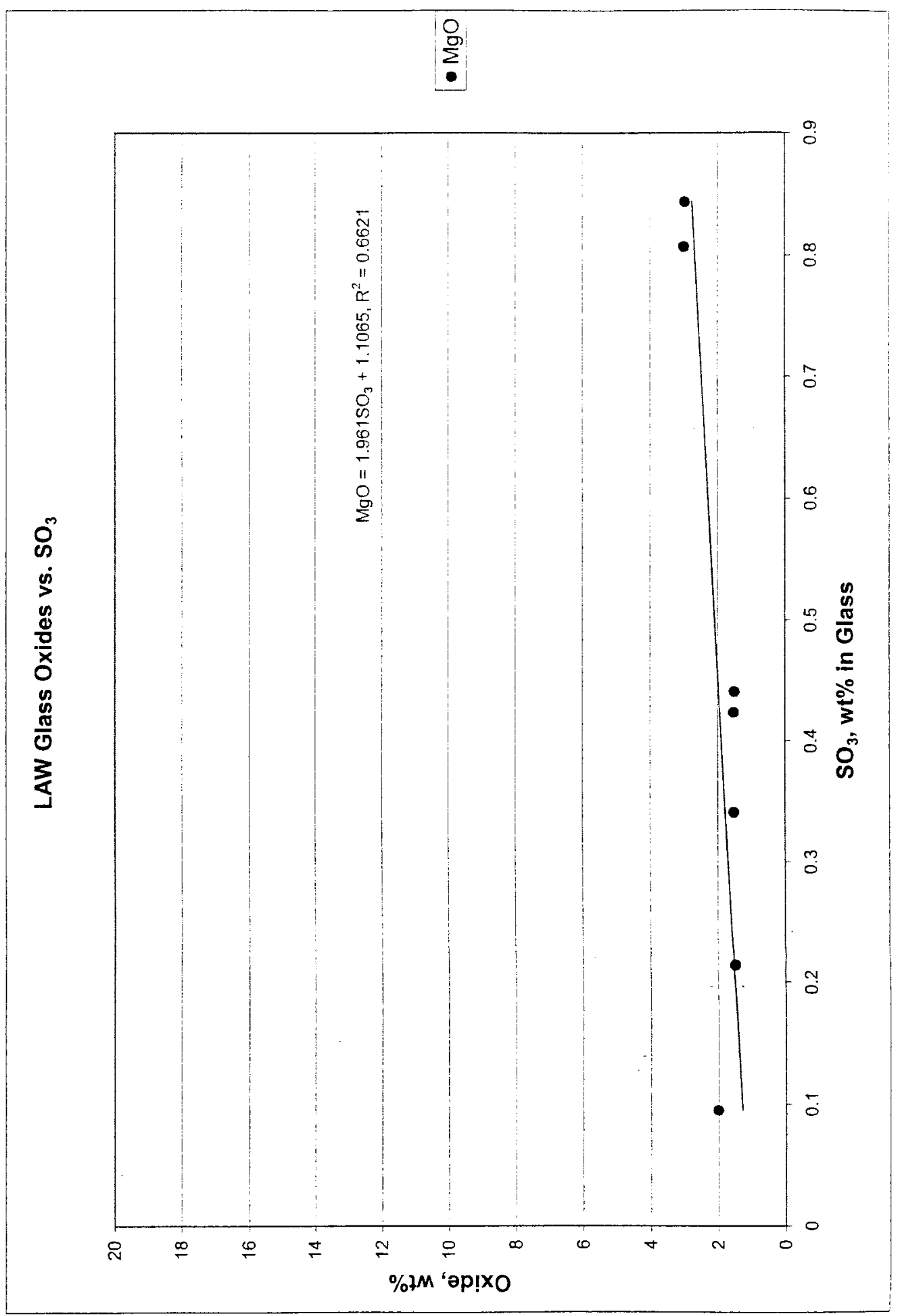


BY: Rod Gimpel

CALC NO.:24590-LAW-M4C-LFP-00002

DATE: $05 / 30 / 02$

SHEET REV: $B$

SUBJECT: Determining the LAW Glass Former Constituents and Amounts for G2 and ACM Models

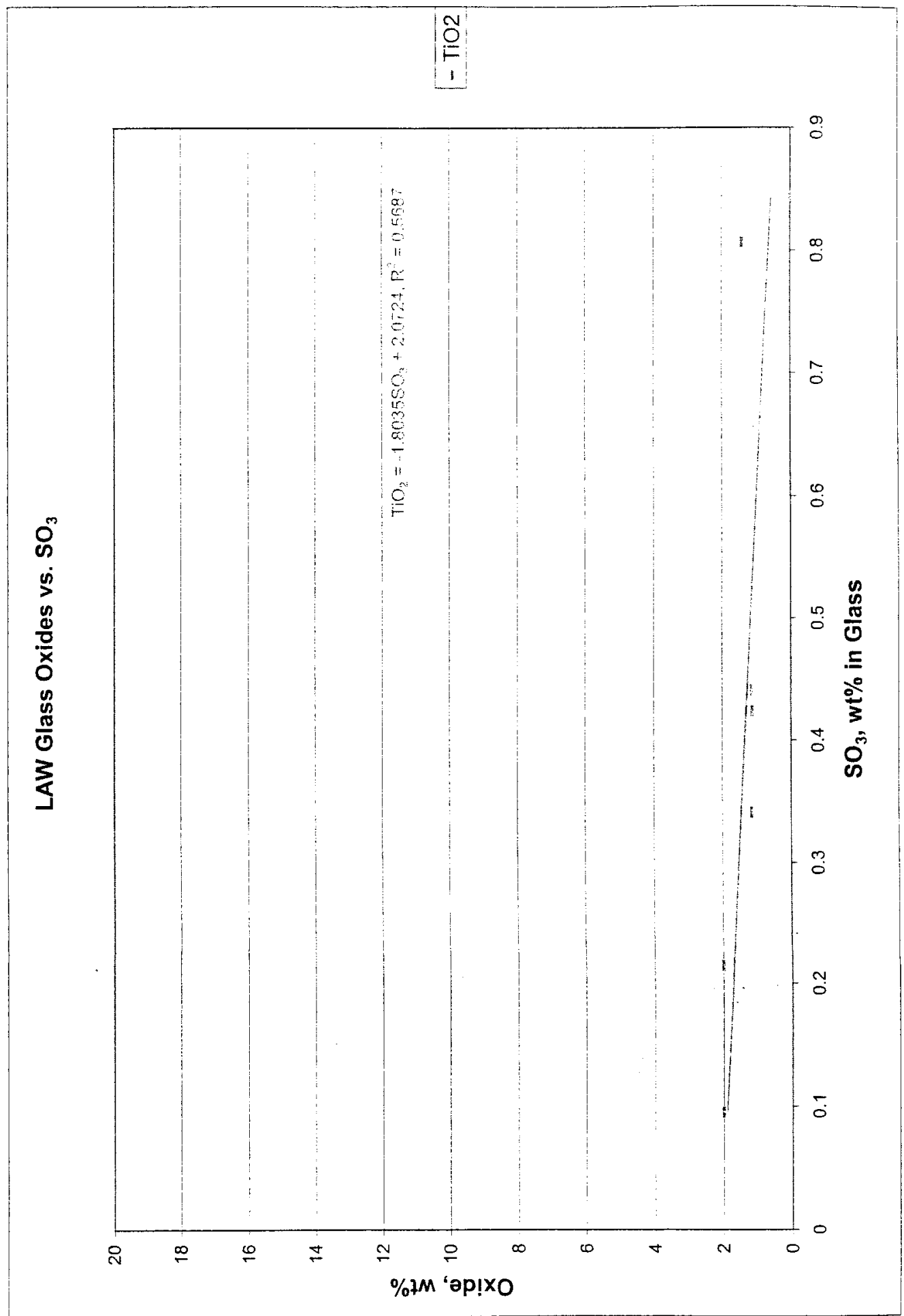




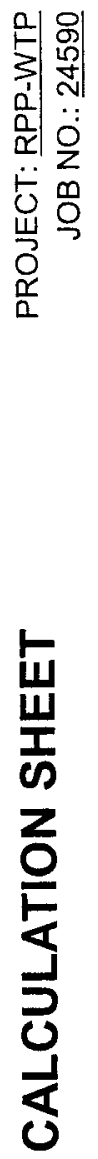

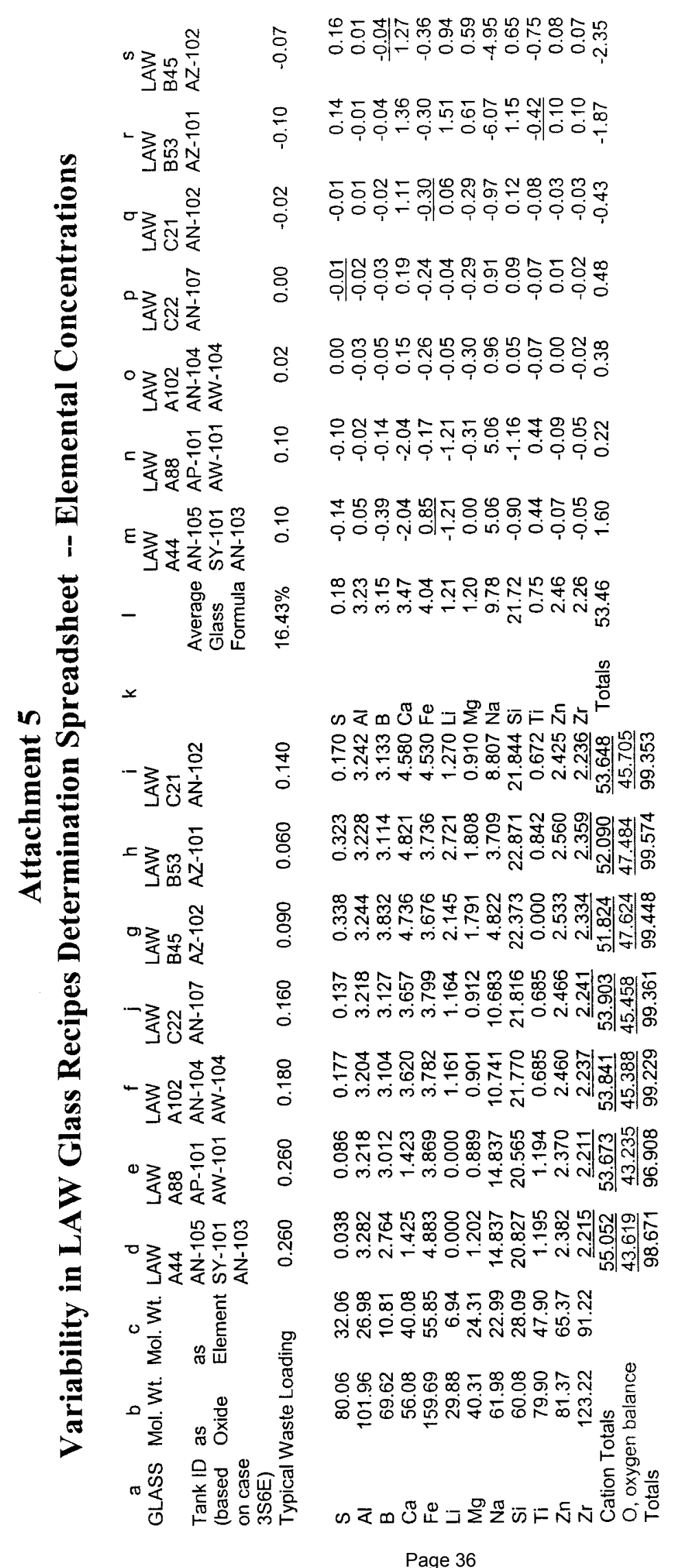

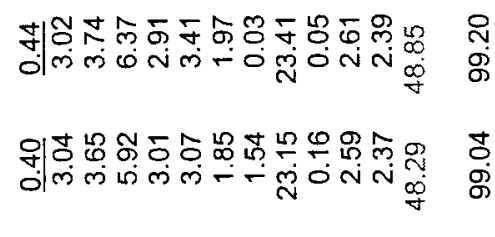

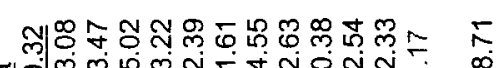

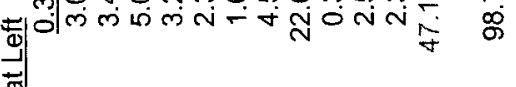

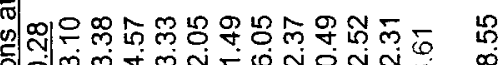

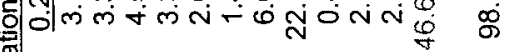

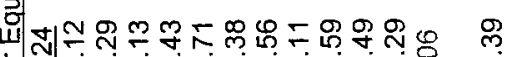

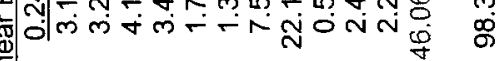

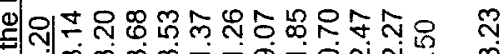

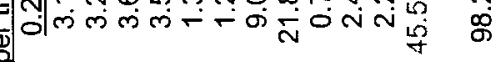

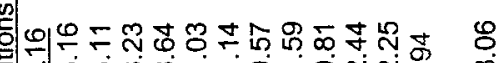

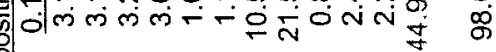

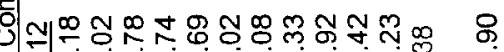

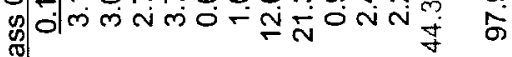

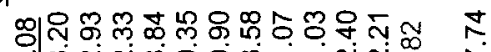

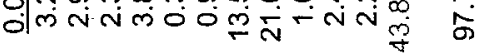

ఫำำ ठึ่

ก

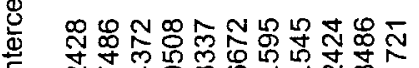

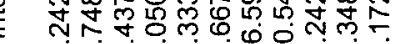
=m

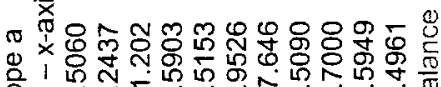

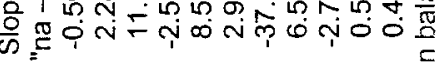

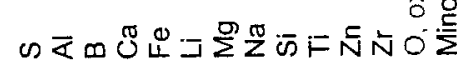






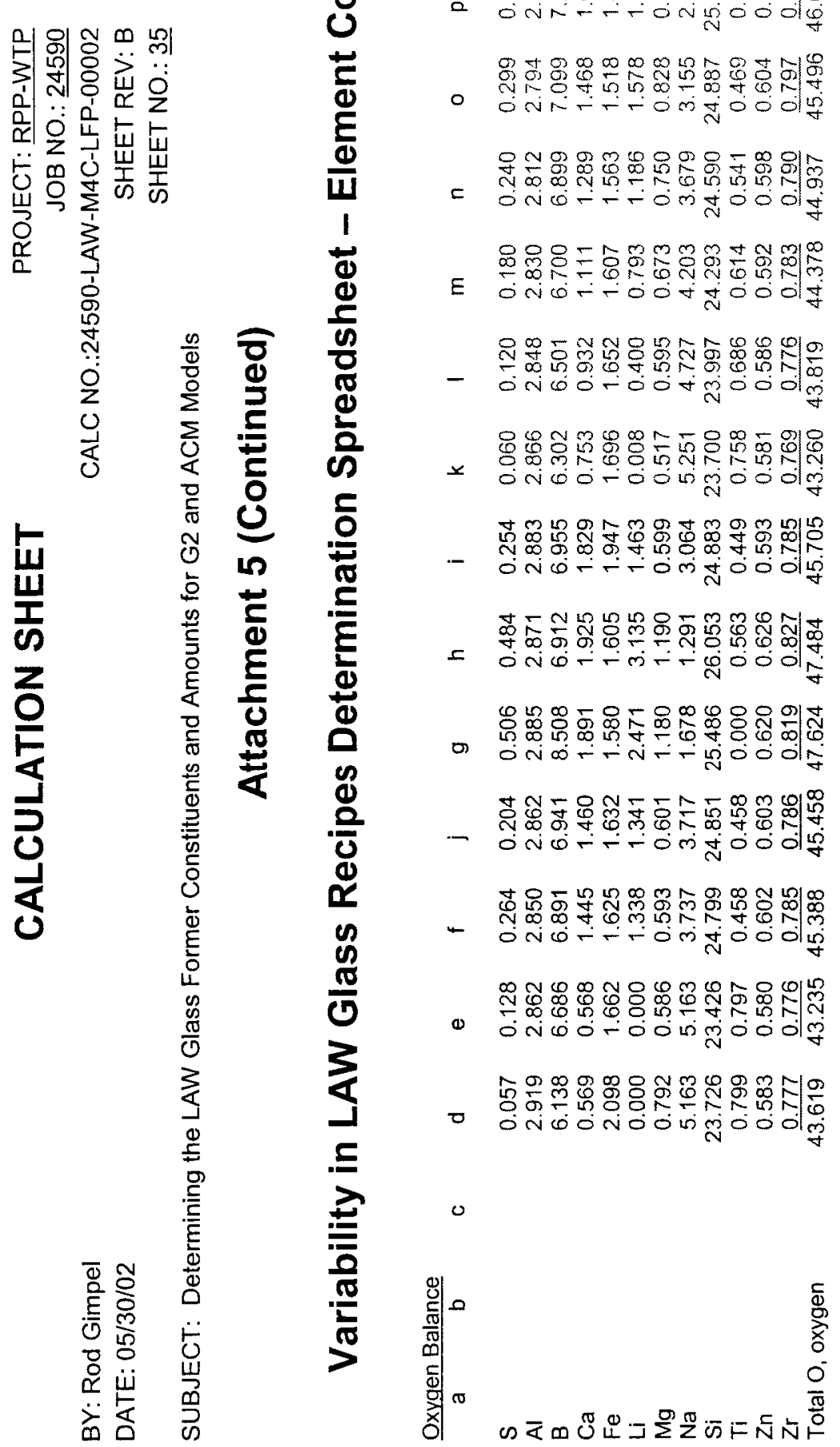


SUBJECT: Determining the LAW Glass Former Constituents and Amounts for G2 and ACM Models

\section{Attachment 5 (Continued)}

\section{Variability in LAW Glass Recipes Determination Spreadsheet -- Elemental Concentrations Formula Displayed Spreadsheet Format}

(13 Pages) 


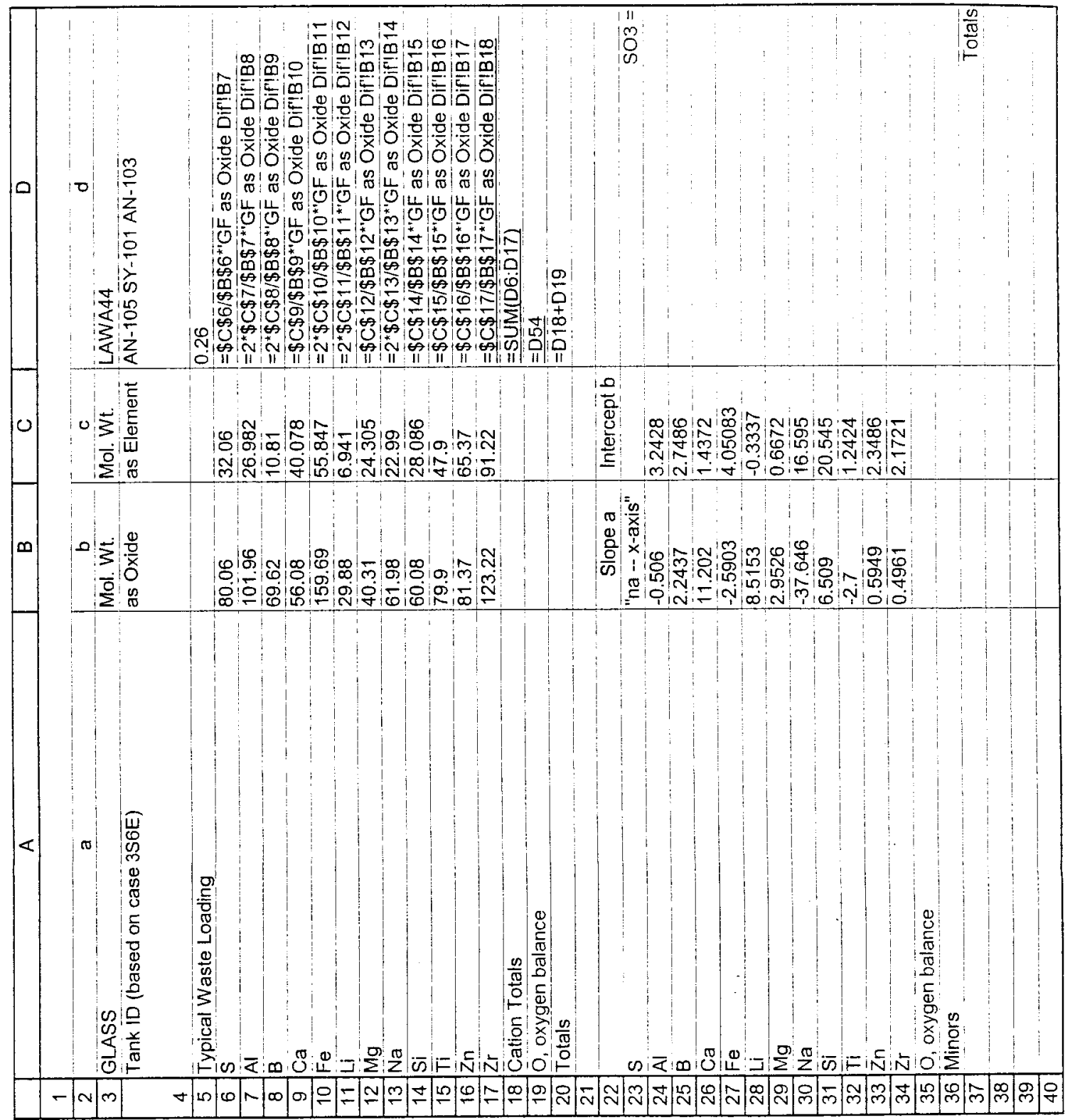


BY: Rod Gimpel

DATE: 05/30/02

SHEET REV: $B$

SUBJECT: Determining the LAW Glass Former Constituents and Amounts for G2 and ACM Models

SHEET NO.: 38

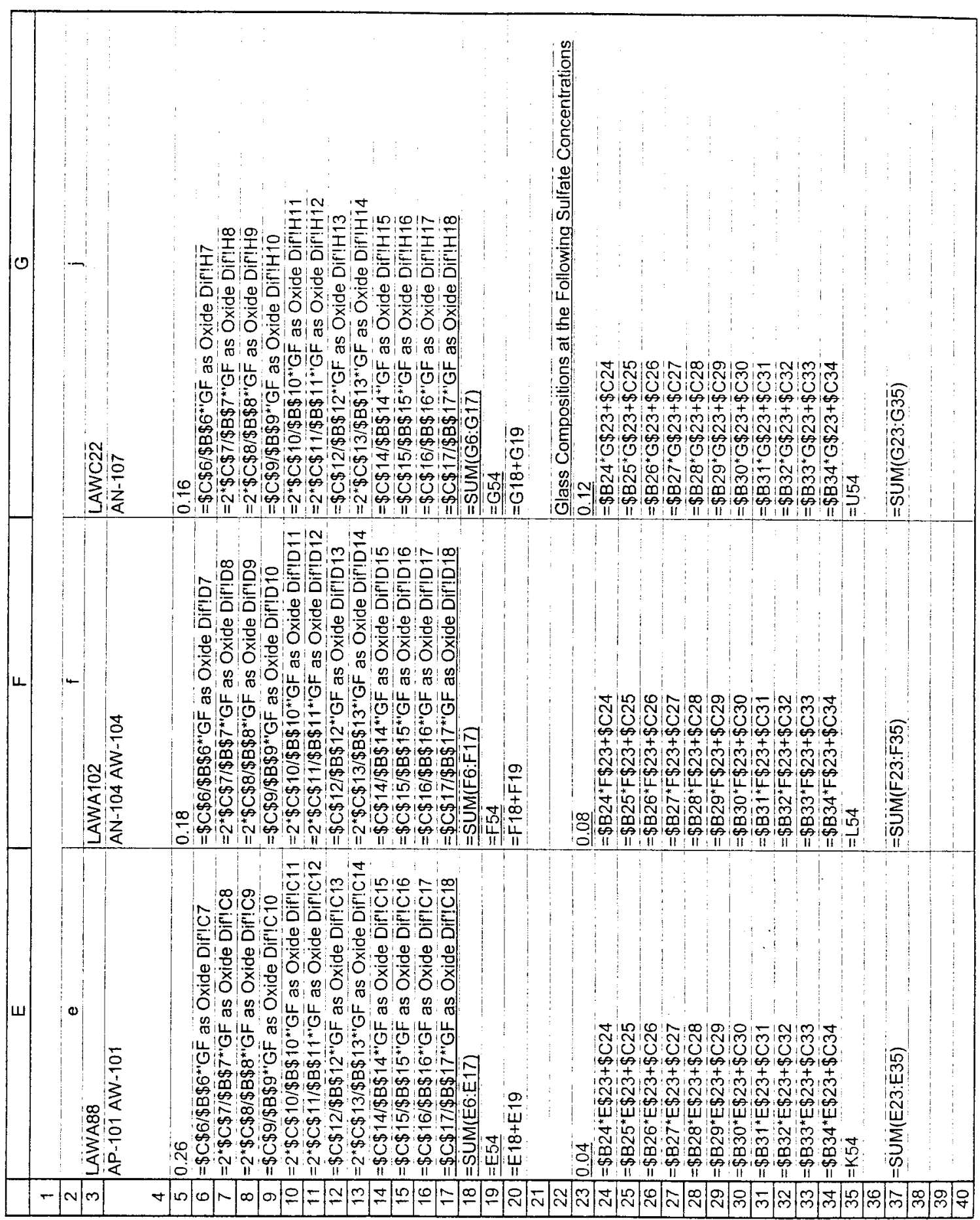


BY: Rod Gimpel

JOB NO

DATE: $05 / 30 / 02$

CALC NO.:24590-LAW-M4C-LFP-00002

SHEET REV: $B$

SHEET NO.: $\underline{39}$

SUBJECT: Determining the LAW Glass Former Constituents and Amounts for G2 and ACM Models

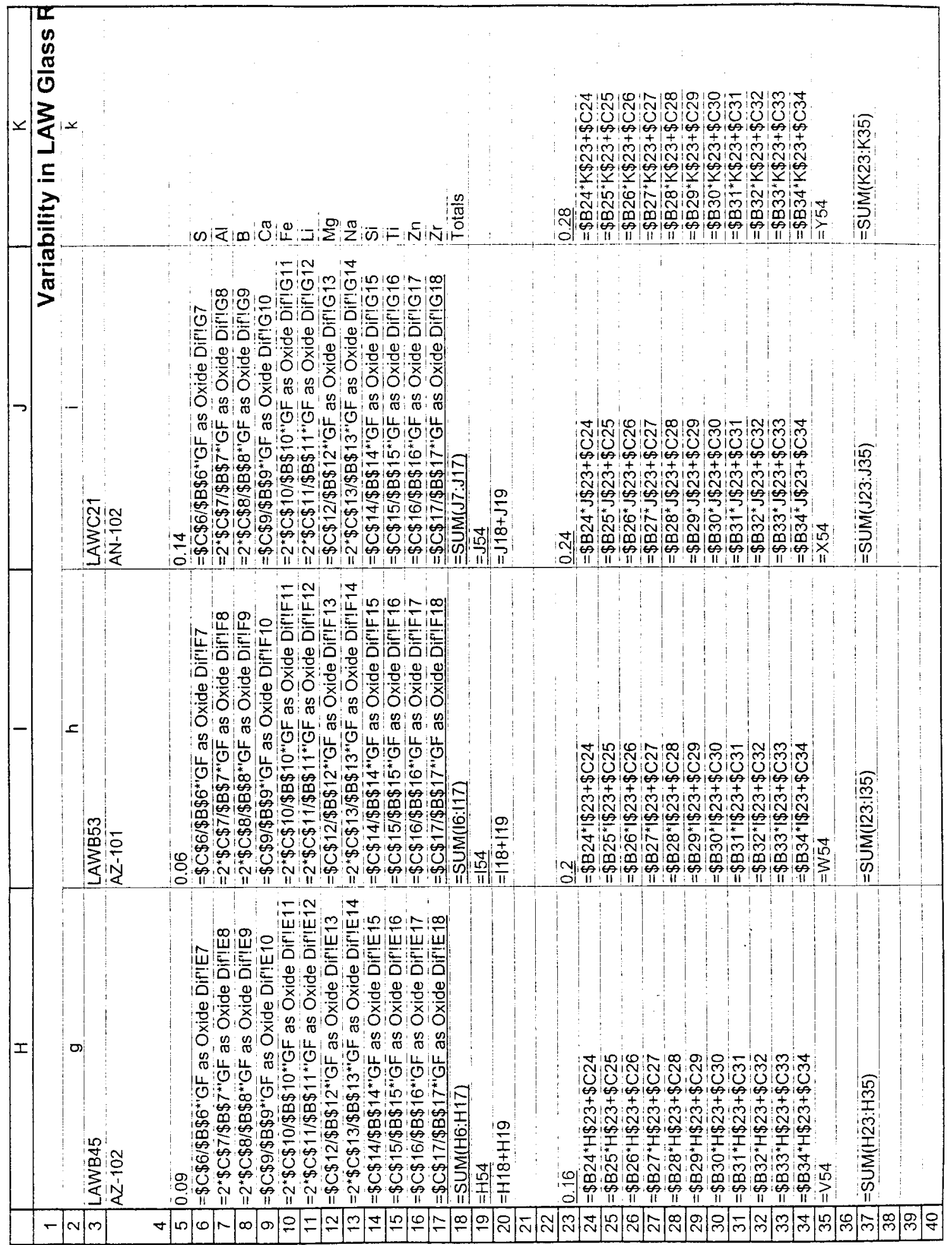




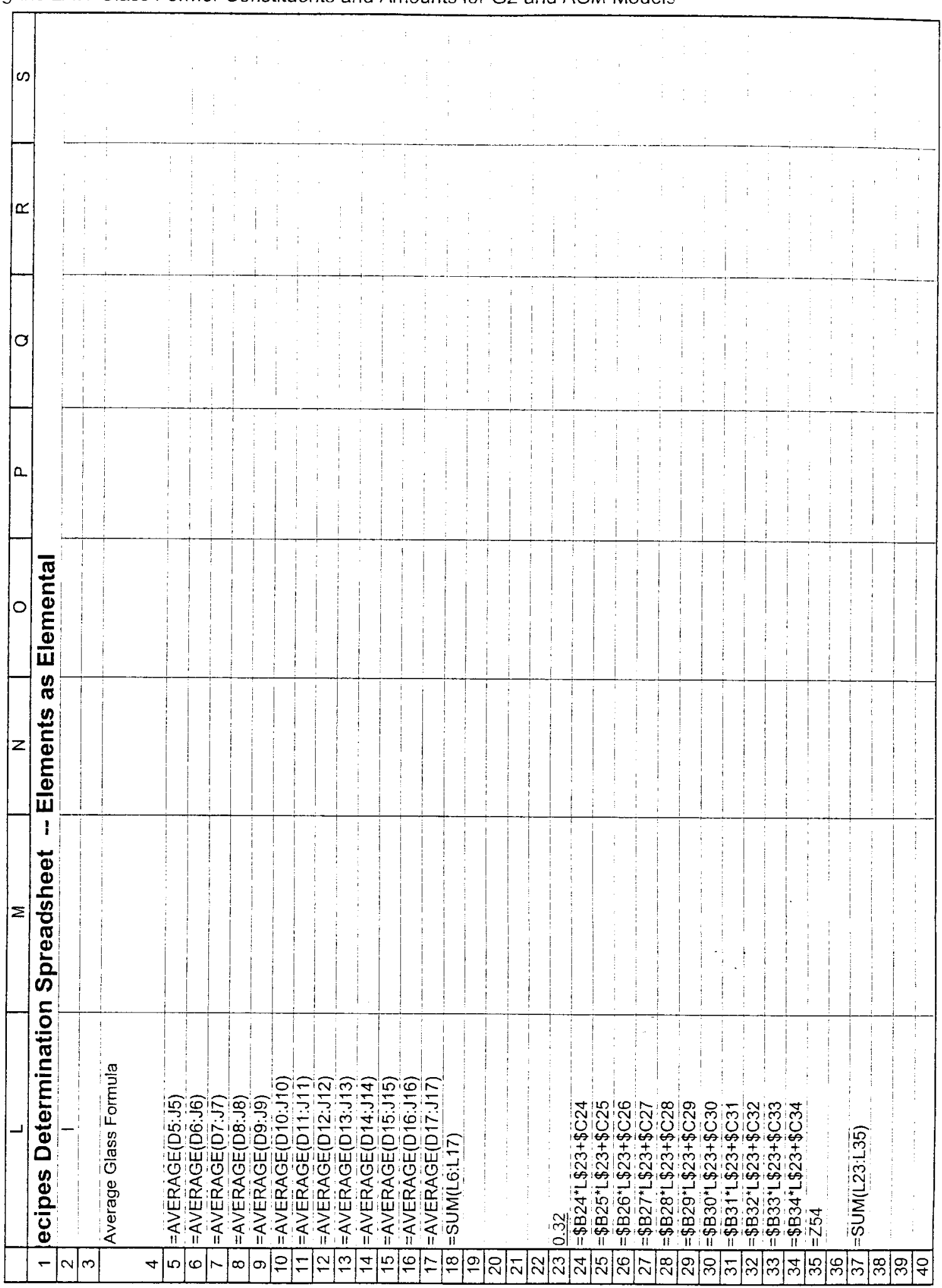


SUBJECT: Determining the LAW Glass Former Constituents and Amounts for G2 and ACM Models

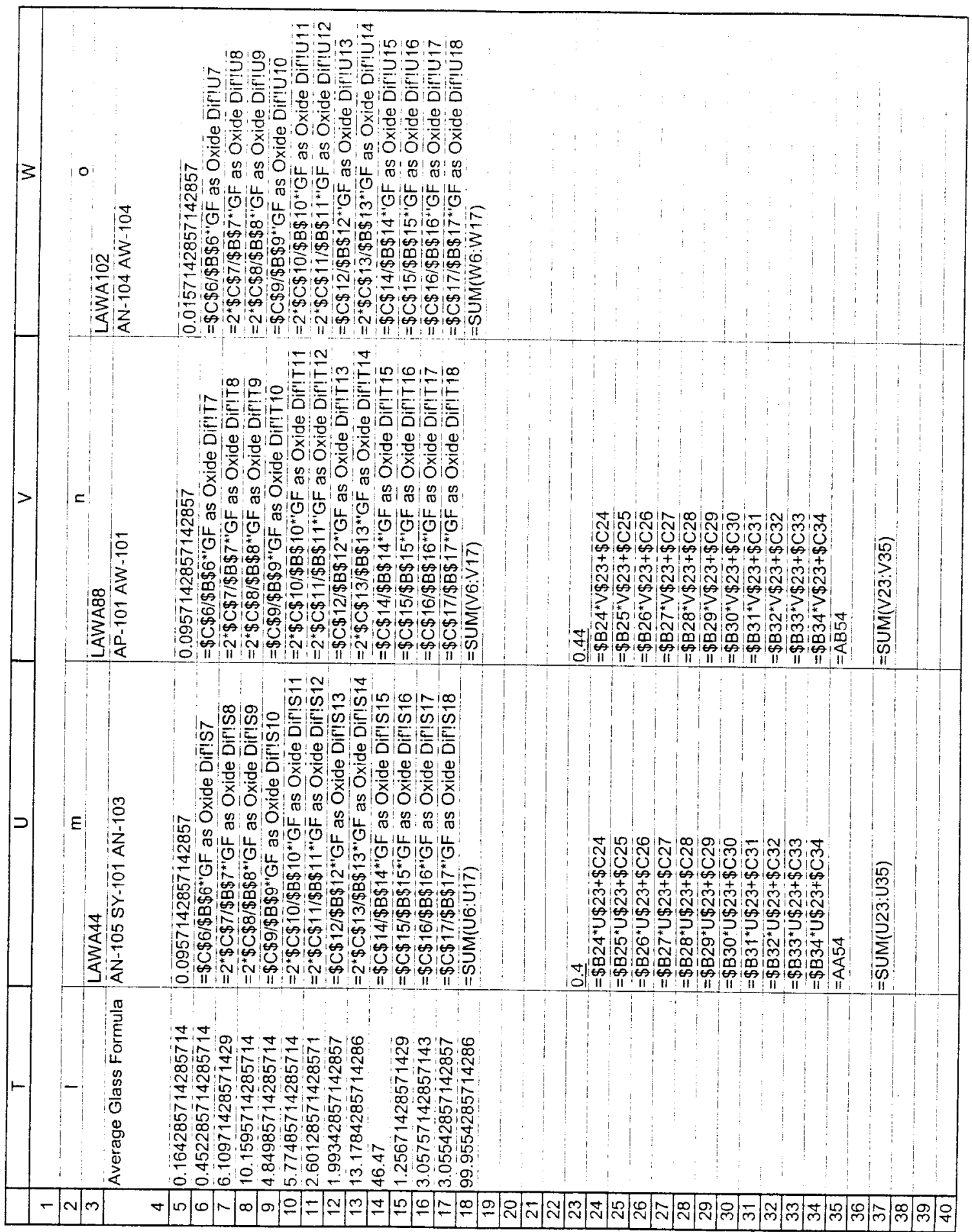




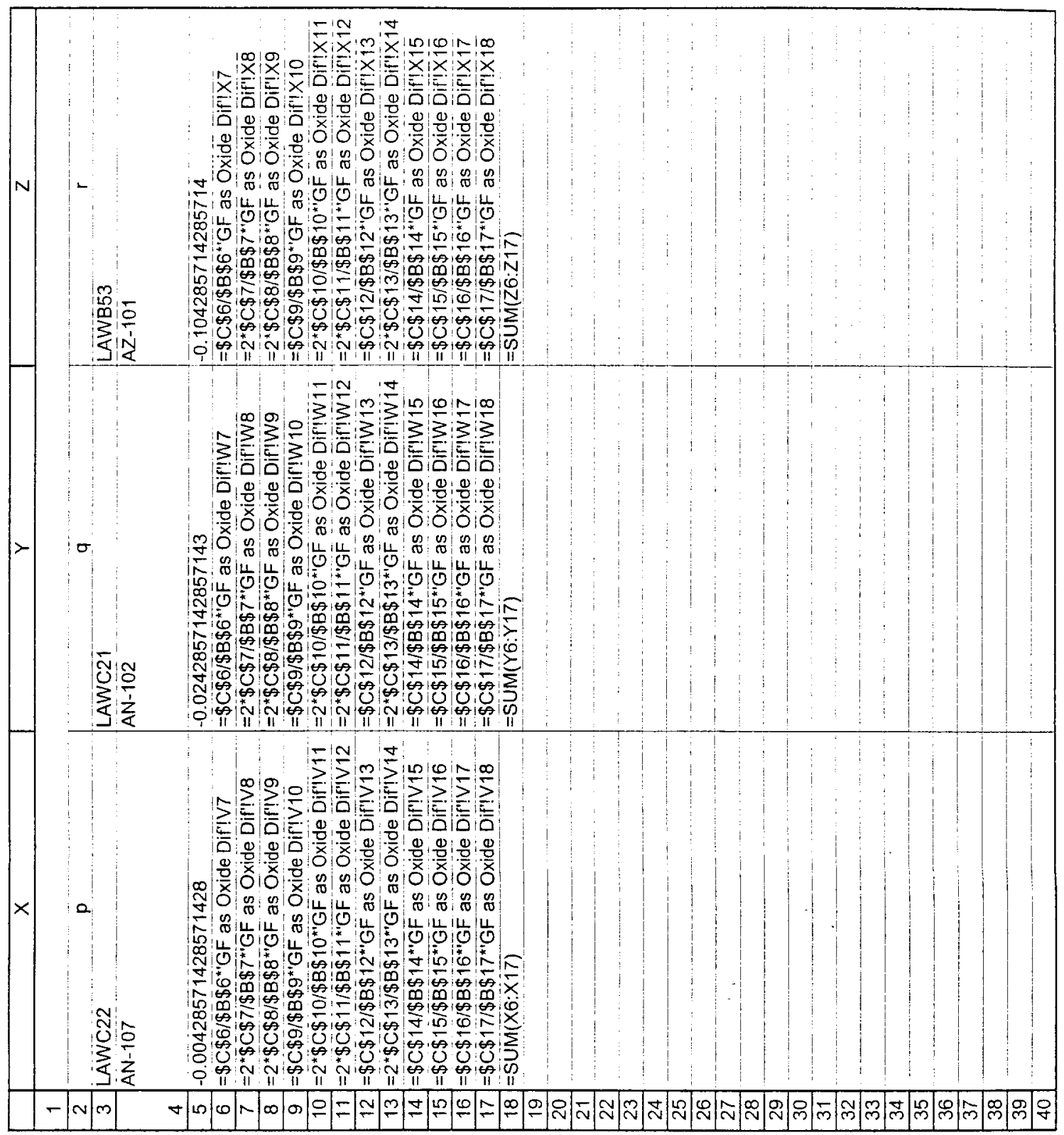


BY: Rod Gimpel

CALC NO.:24590-LAW-M4C-LFP-00002

DATE: 05/30/02

SHEET REV: B

SUBJECT: Determining the LAW Glass Former Constituents and Amounts for G2 and ACM Models

SHEET NO.: 43

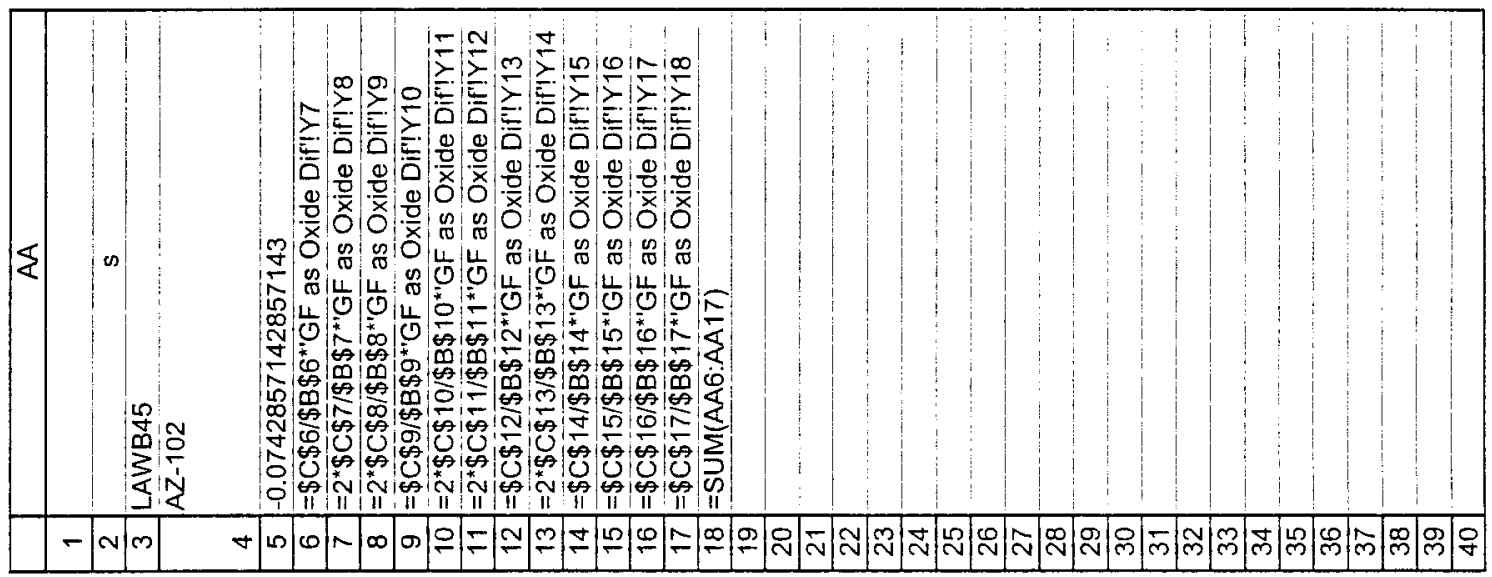



JOB NO.: $\underline{24590}$

BY: Rod Gimpel

DATE: 05/30/02

CALC NO.:24590-LAW-M4C-LFP-00002

SHEET REV: $B$

SUBJECT: Determining the LAW Glass Former Constituents and Amounts for G2 and ACM Models

SHEET NO: 44

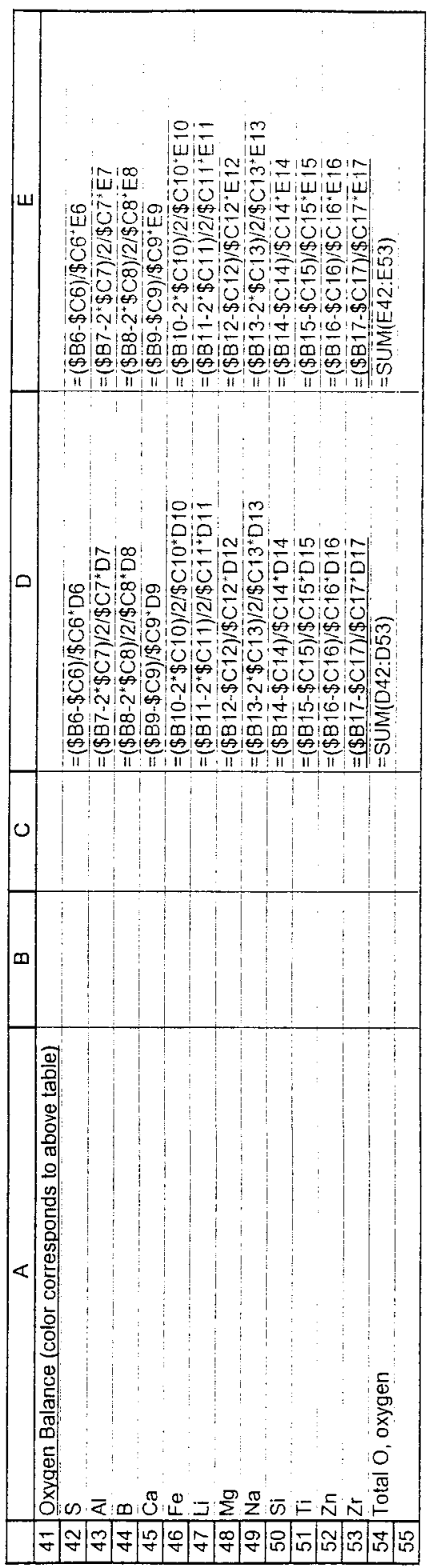




\section{CALCULATION SHEET}

ORP-56511, Rev. B

PROJECT: RPP-WTP

JOB NO.: 24590

BY: Rod Gimpe!

CALC NO.:24590-LAW-M4C-LFP-00002

DATE: 05/30/02

SHEET REV: $B$

SUBJECT: Determining the LAW Glass Former Constituents and Amounts for G2 and ACM Models

SHEET NO.: $\underline{45}$

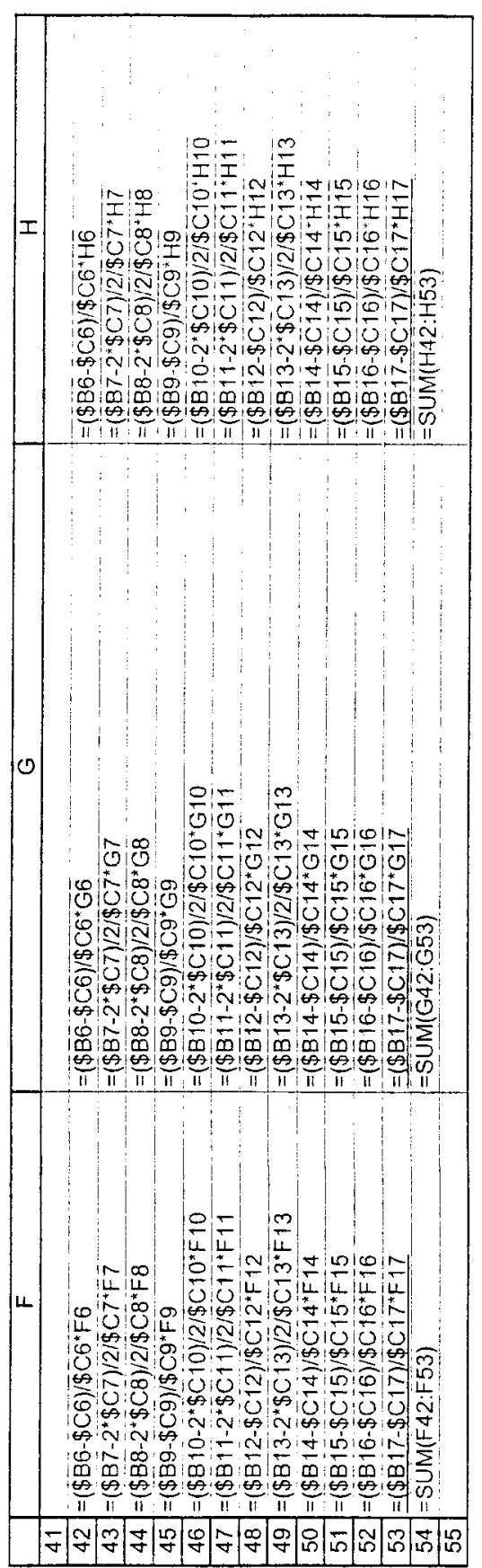


BY: Rod Gimpel

CALC NO.:24590-LAW-M4C-LFP-00002

DATE: 05/30/02

SHEET REV: B

SUBJECT: Determining the LAW Glass Former Constituents and Amounts for G2 and ACM Models

SHEET NO.: $\underline{46}$

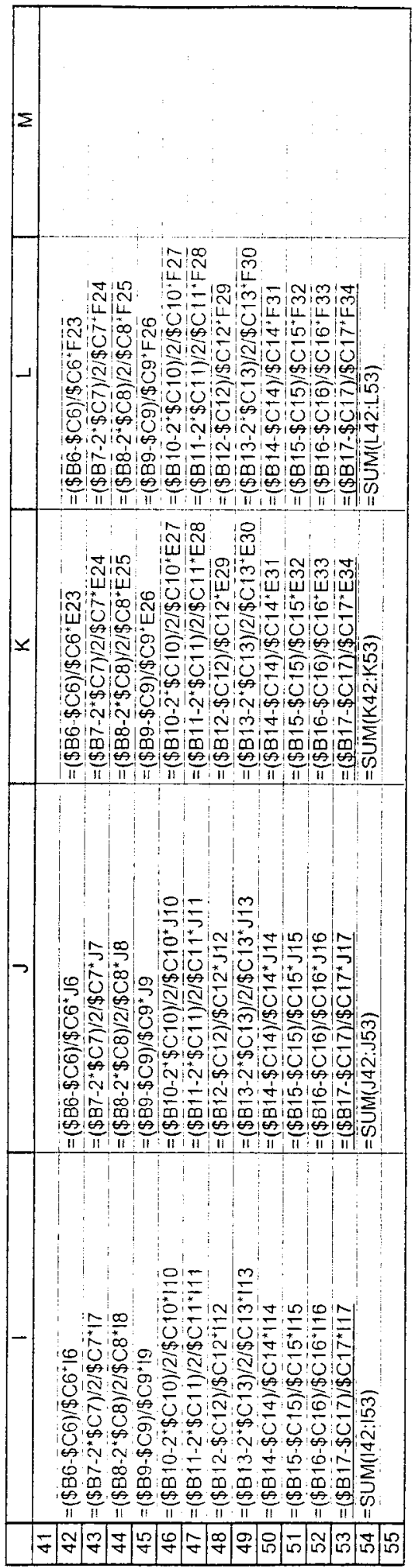



JOB NO.: 24590

BY: Rod Gimpel

DATE: 05/30/02

CALC NO.:24590-LAW-M4C-LFP-00002

SHEET REV: $B$

SUBJECT: Determining the LAW Glass Former Constituents and Amounts for G2 and ACM Models

SHEET NO.: $\underline{47}$

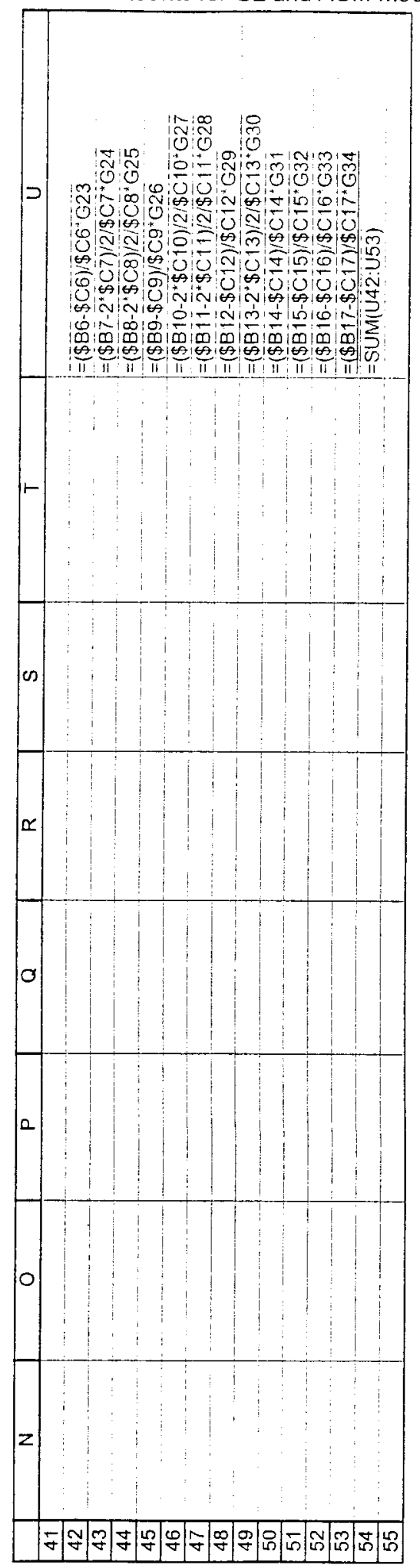


BY: Rod Gimpel

CALC NO.:24590-LAW-M4C-LFP-00002

DATE: 05/30/02

SHEET REV: $B$

SUBJECT: Determining the LAW Glass Former Constituents and Amounts for G2 and ACM Models

SHEET NO.: $\underline{48}$

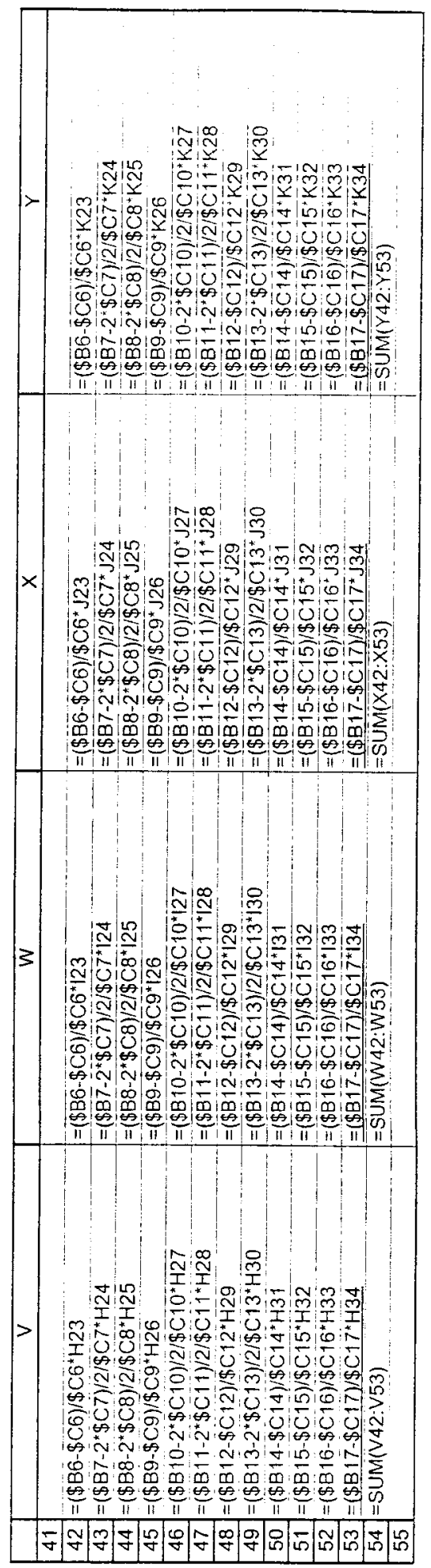


BY: Rod Gimpel

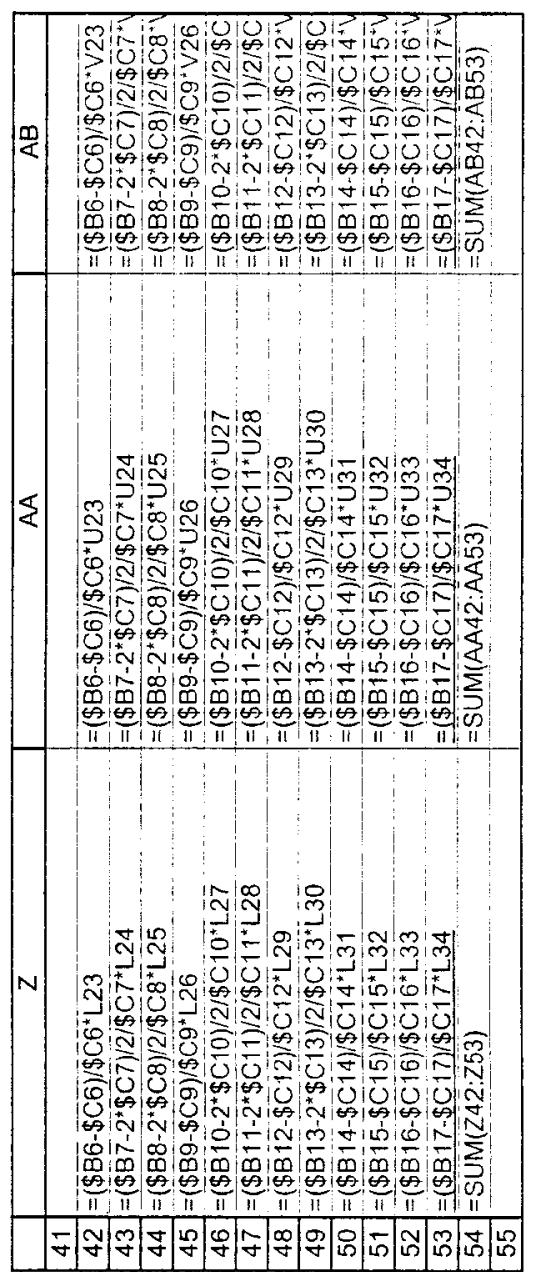




\section{Attachment 5 (Continued)}

\section{Variability in LAW Glass Recipes Determination Spreadsheet -- Elemental Concentrations Formula Displayed Spreadsheet Format}

Spreadsheet's Sheet Name: GF as Oxide Dif.

(3 Pages) 

JOB NO.: 24590

BY: Rod Gimpel CALC NO.:24590-LAW-M4C-LFP-00002

DATE: 05/30/02 SHEET REV: $B$

SUBJECT: Determining the LAW Glass Former Constituents and Amounts for G2 and ACM Models

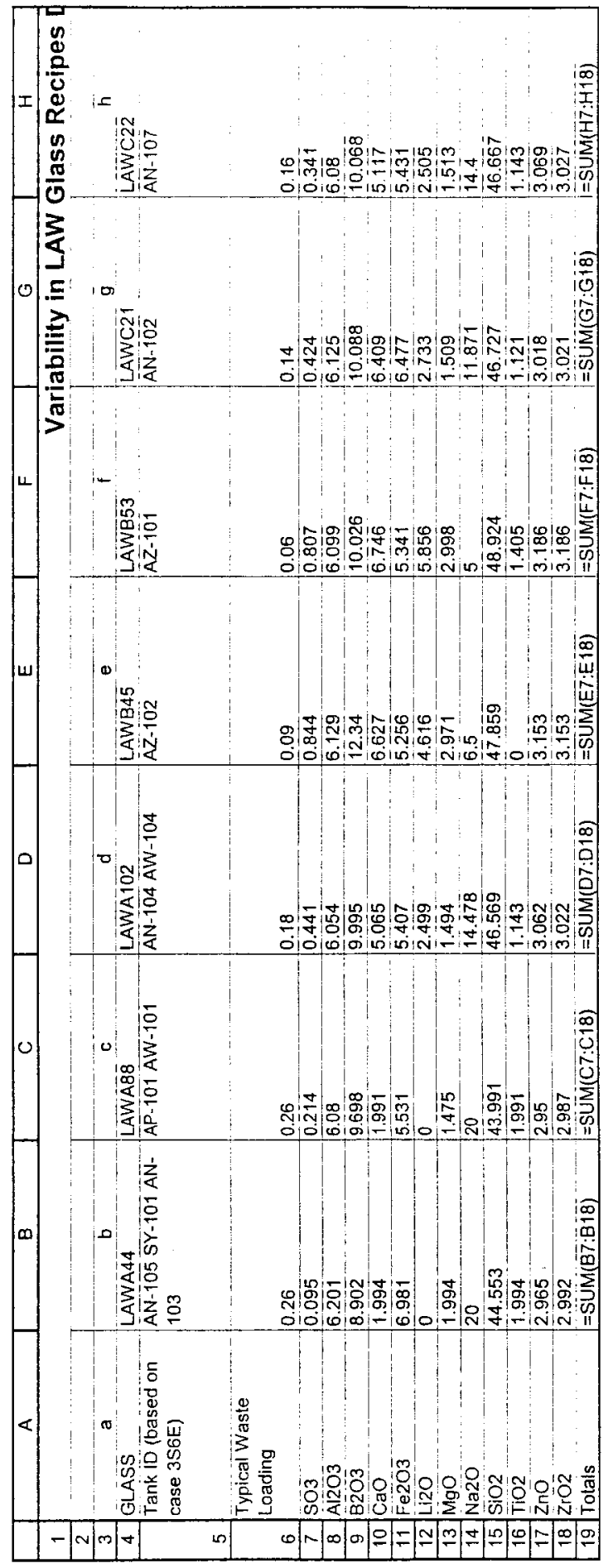


BY: Rod Gimpel

CALC NO:24590-LAW-M4C-LFP-00002

DATE: 05/30/02

SHEET REV: B

SUBJECT: Determining the LAW Glass Former Constituents and Amounts for G2 and ACM Models

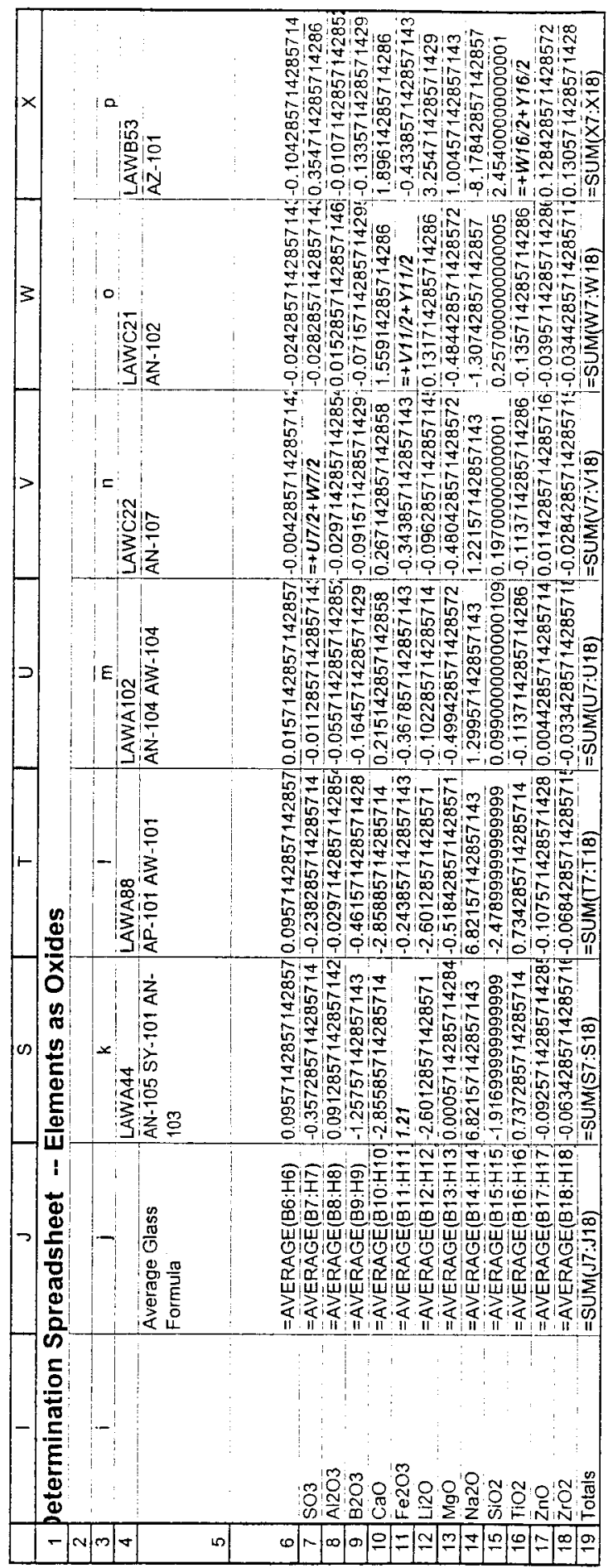



JOB NO.: $\underline{24590}$

BY: Rod Gimpel CALC NO.:24590-LAW-M4C-LFP-00002

DATE: 05/30/02 SHEET REV: B

SUBJECT: Determining the LAW Glass Former Constituents and Amounts for G2 and ACM Models SHEET NO.: $\underline{53}$

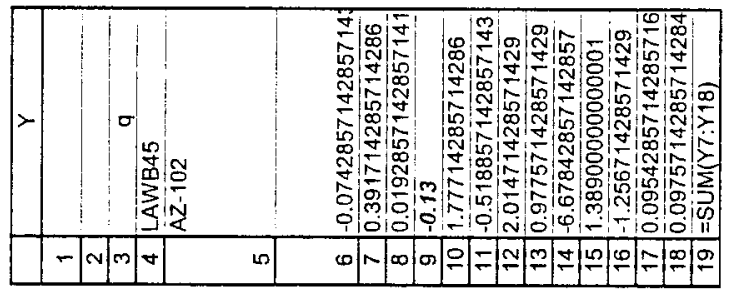




\title{
Attachment 6
}

\section{Law Glass Elements vs. Sulfur Plot}

\author{
(One Page)
}


BY: Rod Gimpel

DATE: 05/30/02

SHEET REV: $B$

SHEET NO.: $\underline{55}$

SUBJECT: Determining the LAW Glass Former Constituents and Amounts for G2 and ACM Models

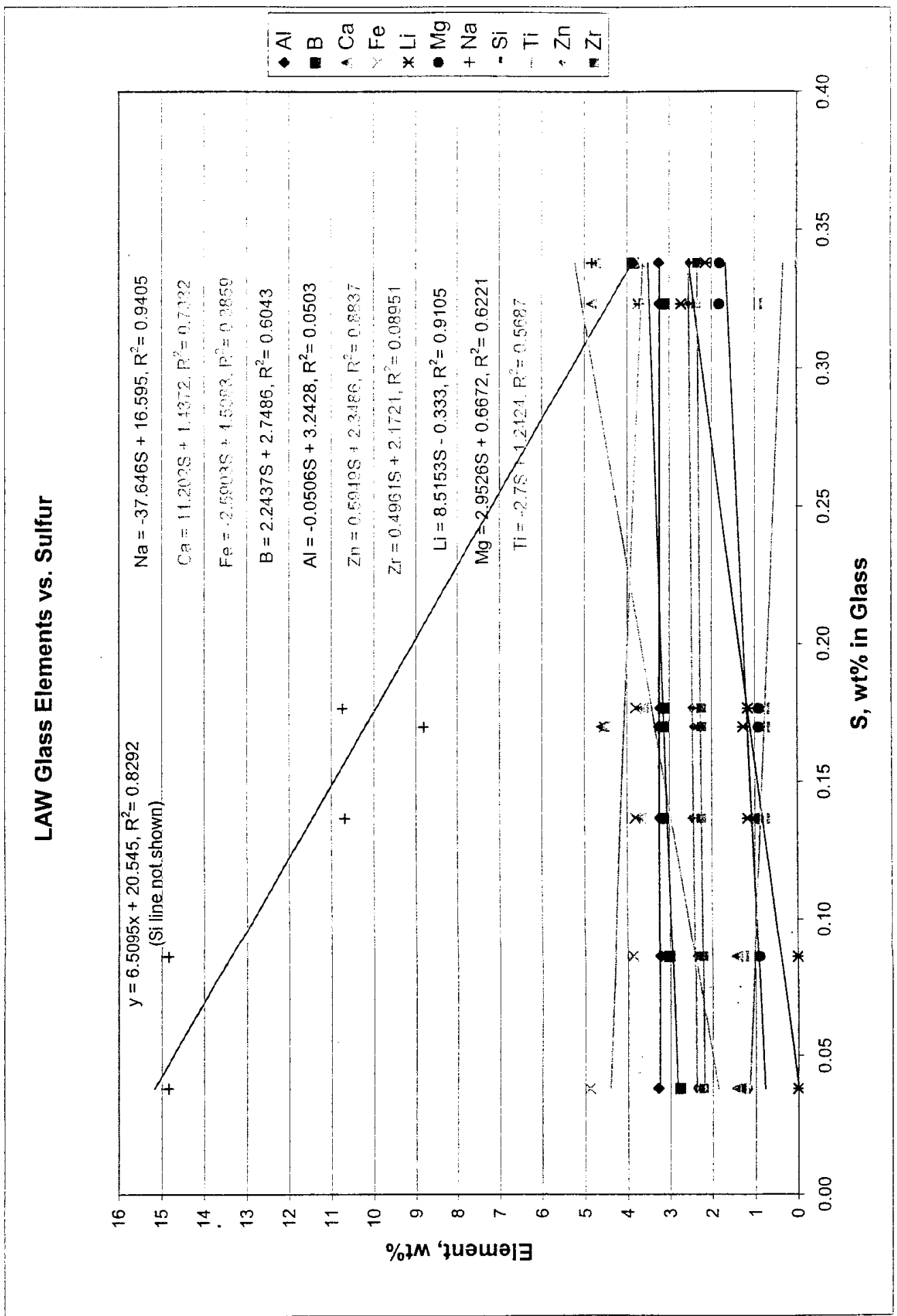




\title{
CALCULATION SHEET
}

CALC NO.:24590-LAW-M4C-LFP-00002 JOB NO.: $\underline{24590}$

BY: Rod Gimpel

DATE: 05/30/02

SHEET REV: B

SUBJECT: Determining the LAW Glass Former Constituents and Amounts for G2 and ACM Models

\author{
Attachment 7 \\ Validation of Use of Microsoft Excel 97 Software
}

(One Page) 


\section{CALCULATION SHEET}

BY: Rod Gimpel

DATE: 05/30/02

SUBJECT: Determining the LAW Glass Former Constituents and Amounts for G2 and ACM Models
ORP-56511, Rev. B

PROJECT: RPP-WTP JOB NO.: 24590

CALC NO.:24590-LAW-M4C-LFP-00002

SHEET REV: $B$

SHEET NO:: $\underline{57}$

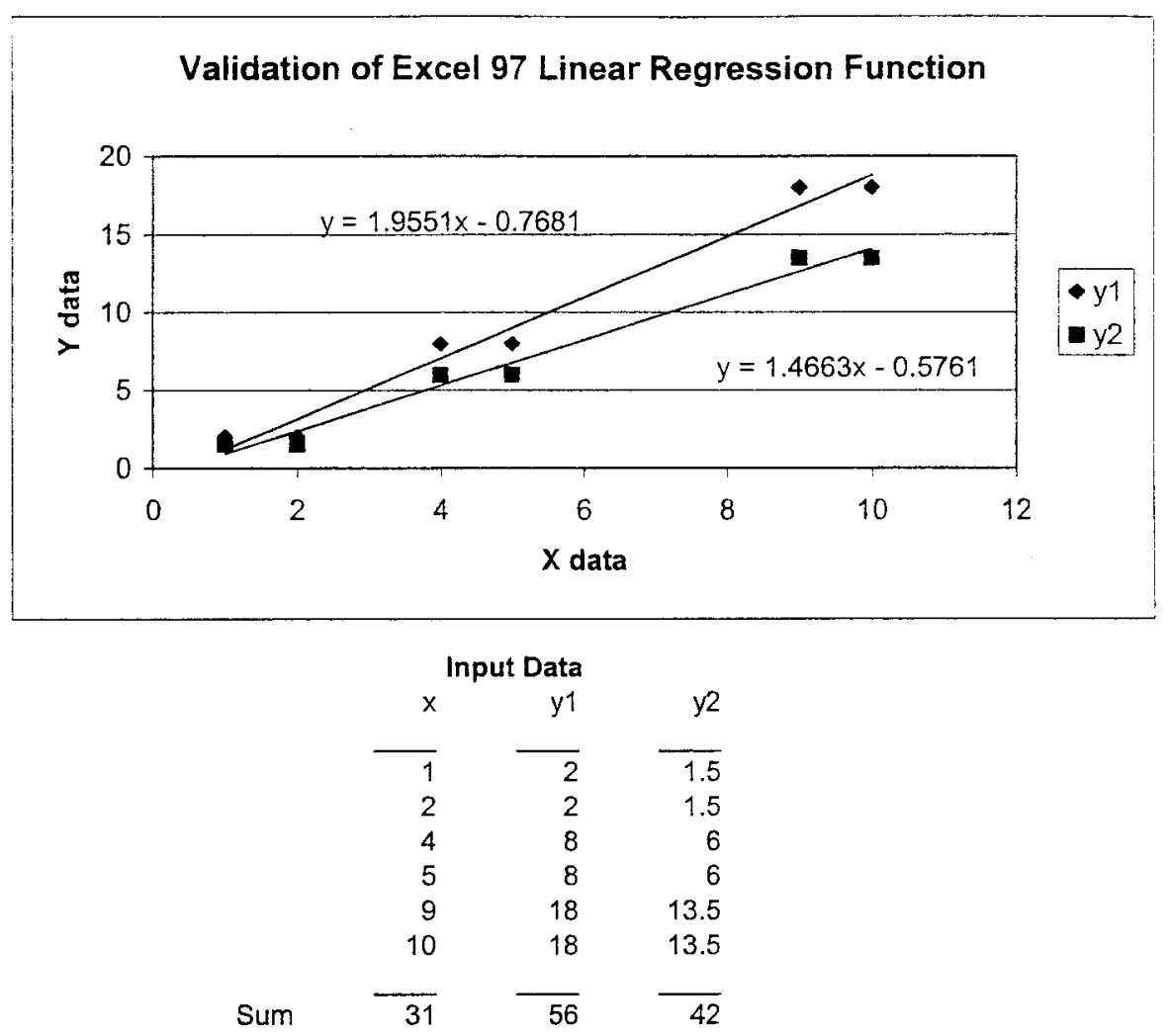

Calibration with Hewlett Packard 32SII Calculator

Calculated values for: Excel 97 HP $32 \mathrm{~S} 11$

y1
Slope, m
Intercept, b
y2
Slope, m
Intercept, b

$1.9551 \quad 1.9551$

$-0.7681-0.7681$

$1.4663 \quad 1.4663$

$-0.5761 \quad-0.5761$ 


\section{CALCULATION SHEET}

BY: Rod Gimpel

PROJECT: RPP-WTP JOB NO.: 24590

DATE: 05/30/02

CALC NO.:24590-LAW-M4C-LFP-00002 SHEET REV: $B$

SUBJECT: Determining the LAW Glass Former Constituents and Amounts for G2 and ACM Models

\section{Attachment 7 (Continued)}

Validation of Use of Microsoft Excel 97 Software Corresponding "Formula Displayed" Spreadsheet Format

(One Page) 
BY: Rod Gimpel

CALC NO.:24590-LAW-M4C-LFP-00002

DATE: $05 / 30 / 02$

SHEET REV: $B$

SUBJECT: Determining the LAW Glass Former Constituents and Amounts for G2 and ACM Mode!s

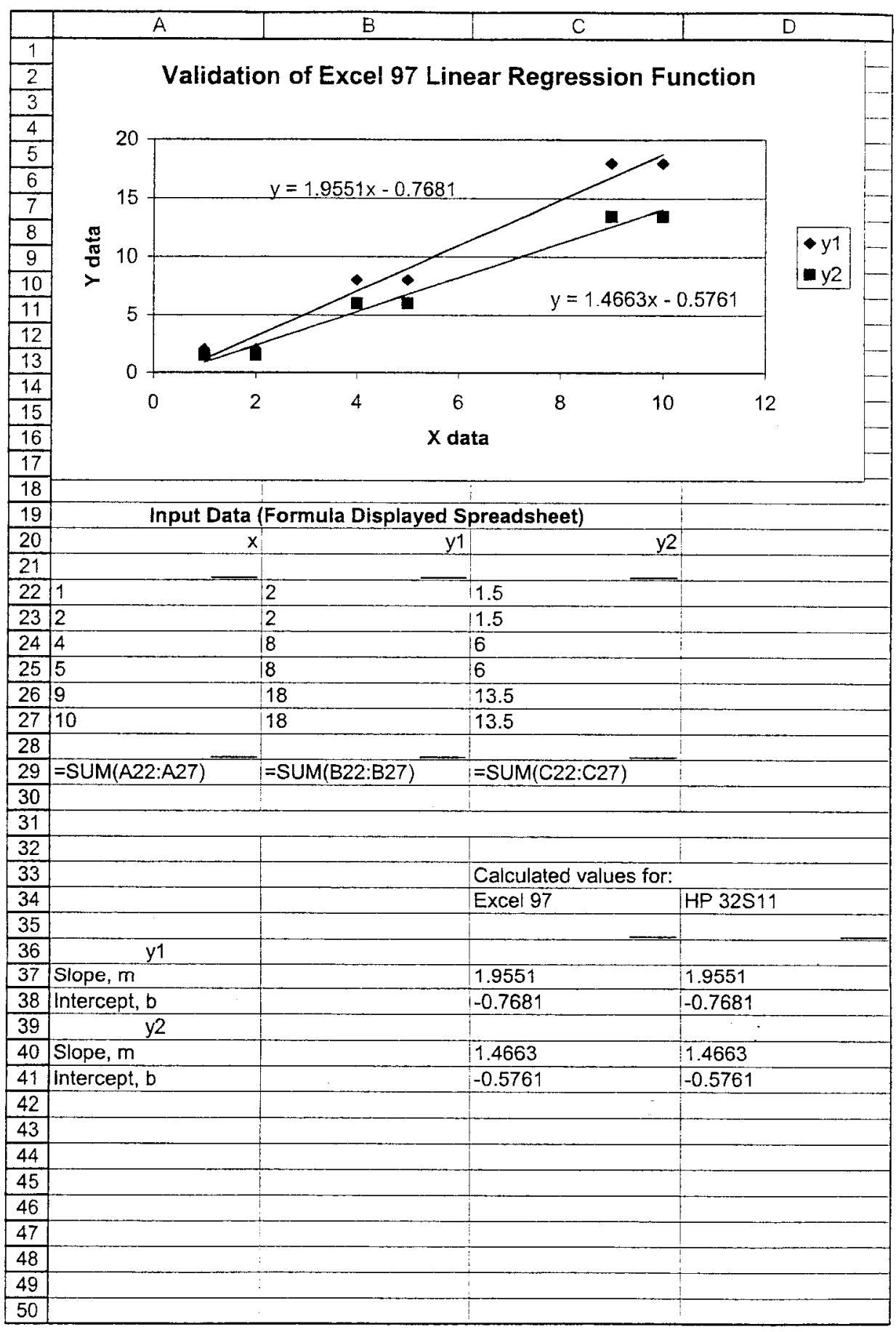




\section{Attachment 8 \\ Equations Microsoft Excel 97 Uses for Calculating Trendlines}

(Six Pages) 
DATE: 05/30/02

SUBJECT: Determining the LAW Glass Former Constituents and Amounts for G2 and ACM Models

\section{Equations for calculating trendlines}

\section{Linear}

Calculates the least squares fit for a line represented by the following equation:

$y=m x+b$

where $m$ is the slope and $b$ is the intercept.

\section{Polynomial}

Calculates the least squares fit through points by using the following equation:

$y=b+c_{1} x+c_{2} x^{2}+c_{3} x^{3}+\ldots+c_{6} x^{6}$

where $b$ and $c_{1} \ldots C_{6}$ are constants.

Logarithmic

Calculates the least squares fit through points by using the following equation:

$y=c \ln x+b$

where $c$ and $b$ are constants, and $\ln$ is the natural logarithm function.

Exponential

Calculates the least squares fit through points by using the following equation:

$y=c e^{b x}$

where $c$ and $b$ are constants, and $e$ is the base of the natural logarithm.

\section{Power}

Calculates the least squares fit through points by using the following equation:

$y=c x^{b}$

where $c$ and $b$ are constants.

\section{R-squared Value}

$$
\begin{aligned}
& R^{2}=1-\frac{S S E}{S S T} \\
& \text { where } \\
& S S E=\sum\left(Y_{i}-\hat{Y}\right)^{2} \\
& \text { and } \\
& S S T=\left(\sum Y_{i}^{2}\right)-\frac{\left(\sum Y\right)^{2}}{n}
\end{aligned}
$$

Note The R-squared value you can display with a trendline is not an adjusted R-squared value. For logarithmic, power, and exponential trendlines, Microsoft Excel uses a transformed regression model.

Moving Average

$F_{t}=\frac{A_{r}+A_{r-1}+\ldots A_{t-n+1}}{n}$

Note The number of points in a moving average trendline equals the total number of points in the series less the number you specify for the period. 


\section{LINEST}

\section{$\underline{\text { See Also }}$}

Calculates the statistics for a line by using the "least squares" method to calculate a straight line that best fits your data, and returns an array that describes the line. Because this function returns an array of values, it must be entered as an array formula. For more information about array formulas, click

The equation for the line is:

$y=m x+b$ or $y=m 1 x 1+m 2 x 2+\ldots+b$ (if there are multiple ranges of $x$-values)

where the dependent $y$-value is a function of the independent $x$-values. The $m$-values are coefficients corresponding to each $x$-value, and $b$ is a constant value. Note that $y, x$, and $m$ can be vectors. The array that LINEST returns is $\{m n, m n-1, \ldots, m 1, b\}$. LINEST can also return additional regression statistics.

\section{Syntax}

LINEST(known_y's, known_x's, const,stats)

Known_y's is the set of $y$-values you already know in the relationship $y=m x+b$.

- If the array known $y$ 's is in a single column, then each column of known $x$ 's is interpreted as a separate variable.

- If the array known_y's is in a single row, then each row of known_x's is interpreted as a separate variable.

Known_x's is an optional set of $x$-values that you may already know in the relationship $y=m x+b$.

- The array known_x's can include one or more sets of variables. If only one variable is used, known_y's and known_x's can be ranges of any shape, as long as they have equal dimensions. If more than one variable is used, known $y$ 's must be a vector (that is, a range with a height of one row or a width of one column).

- If known_x's is omitted, it is assumed to be the array $\{1,2,3, \ldots\}$ that is the same size as known_y's.

Const is a logical value specifying whether to force the constant $b$ to equal 0 .

- If const is TRUE or omitted, $b$ is calculated normally.

- If const is FALSE, $b$ is set equal to 0 and the $m$-values are adjusted to fit $y=m x$.

Stats is a logical value specifying whether to return additional regression statistics.

- If stats is TRUE, LINEST returns the additional regression statistics, so the returned array is $\{m n, m n-1, \ldots, m 1, b ;$ sen, sen-1,...,se1,seb;r2,sey; F, df;ssreg,ssresid\}.

- If stats is FALSE or omitted, LINEST returns only the m-coefficients and the constant $b$.

The additional regression statistics are as follows.

$\begin{array}{ll}\text { Statistic } & \text { Description } \\ \text { se1,se2,...,sen } & \text { The standard error values for the coefficients } \\ \text { Seb } & \mathrm{m} 1, \mathrm{~m} 2, \ldots, \mathrm{mn} . \\ & \text { The standard error value for the constant b (seb = \#N/A } \\ \text { when const is FALSE). } & \text { The coefficient of determination. Compares estimated } \\ & \text { and actual y-values, and ranges in value from } 0 \text { to } 1 . \text { If } \\ & \text { it is } 1, \text { there is a perfect correlation in the sample - } \\ & \text { there is no difference between the estimated y-value } \\ & \text { and the actual y-value. At the other extreme, if the } \\ & \text { coefficient of determination is } 0, \text { the regression } \\ & \text { equation is not helpful in predicting a y-value. For } \\ & \text { information about how } \mathrm{r} 2 \text { is calculated, see "Remarks" }\end{array}$




$\begin{array}{ll}\text { sey } & \text { later in this topic. } \\ \text { F } & \text { The standard error for the y estimate. } \\ & \text { The F statistic, or the F-observed value. Use the F } \\ \text { statistic to determine whether the observed relationship } \\ \text { between the dependent and independent variables } \\ \text { occurs by chance. } \\ \text { The degrees of freedom. Use the degrees of freedom } \\ \text { df } \\ \text { to help you find F-critical values in a statistical tabie. } \\ \text { Compare the values you find in the table to the F } \\ \text { statistic returned by LINEST to determine a confidence } \\ \text { level for the model. } \\ \text { ssreg } & \text { The regression sum of squares. } \\ \text { ssresid } & \text { The residual sum of squares. }\end{array}$

The following iliustration shows the order in which the additional regression statistics are returned.

\begin{tabular}{|c|c|c|c|c|c|}
\hline & $\mathrm{A}$ & $\mathrm{THB}, \mathrm{C}$ & $\mathrm{OQ}$ & E & 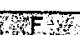 \\
\hline 1 & $m_{n}$ & $m_{n-1}$ & $m_{2}$ & $m_{1}$ & $\mathrm{~b}$ \\
\hline 2 & $\mathrm{se}_{\mathrm{r}}$ & $\operatorname{se}_{n-1}$ & $\mathrm{se}_{2}$ & se & $s e_{b}$ \\
\hline 3 & $r_{2}$ & $\mathrm{se}_{\mathrm{V}}$ & & & \\
\hline 4 & $F$ & $d_{f}$ & & & \\
\hline 5 & $s s_{r e}$ & resio & & & \\
\hline
\end{tabular}

\section{Remarks}

- You can describe any straight line with the slope and the $y$-intercept: Slope $(\mathrm{m})$ :

To find the slope of a line, often written as $m$, take two points on the line, $(x 1, y 1)$ and $(x 2, y 2)$; the slope is equal to $(y 2-y 1) /(x 2-x 1)$.

Y-intercept (b):

The $y$-intercept of a line, often written as $b$, is the value of $y$ at the point where the line crosses the $y$-axis.

The equation of a straight line is $y=m x+b$. Once you know the values of $m$ and $b$, you can calculate any point on the line by plugging the $y$ - or $x$-value into that equation. You can also use the TREND function. For more information, see TREND.

- When you have only one independent $x$-variable, you can obtain the slope and $y$-intercept values directly by using the following formulas:

Slope:

INDEX(LINEST(known_y's,known_X's), 1)

Y-intercept:

INDEX(LINEST(known_y's,known_x's),2)

- The accuracy of the line calculated by LINEST depends on the degree of scatter in your data. The more linear the data, the more accurate the LINEST model. LINEST uses the method of least squares for determining the best fit for the data. When you have only one independent $x$-variable, the calculations for $m$ and $b$ are based on the following formulas:

$$
\begin{aligned}
& m=\frac{n\left(\sum x\right)\left(\sum x\right)\left(\sum y\right)}{n\left(\sum\left(x^{2}\right)\right)-\left(\sum x\right)^{2}} \\
& b=\frac{\left(\sum y\right)\left(\sum\left(x^{2}\right)\right)-\left(\sum x\right)\left(\sum x y\right)}{n\left(\sum\left(x^{2}\right)\right)-\left(\sum x\right)^{2}}
\end{aligned}
$$


- The line- and curve-fitting functions LINEST and LOGEST can calculate the best straight line or exponential curve that fits your data. However, you have to decide which of the two results best fits your data. You can calculate TREND(known_y's,known_x's) for a straight line, or GROWTH(known_y's, known_x's) for an exponential curve. These functions, without the new_x's argument, return an array of $y$-values predicted along that line or curve at your actual data points. You can then compare the predicted values with the actual values. You may want to chart them both for a visual comparison.

- In regression analysis, Microsoft Excel calculates for each point the squared difference between the $y$-value estimated for that point and its actual $y$-value. The sum of these squared differences is called the residual sum of squares. Microsoft Excel then calculates the sum of the squared differences between the actual $y$-values and the average of the $y$-values, which is called the total sum of squares (regression sum of squares + residual sum of squares). The smaller the residual sum of squares is, compared with the total sum of squares, the larger the value of the coefficient of determination, $\mathrm{r} 2$, which is an indicator of how well the equation resulting from the regression analysis explains the relationship among the variables.

- Formulas that return arrays must be entered as array formulas. For more information about entering array formulas, click

- When entering an array constant such as known_x's as an argument, use commas to separate values in the same row and semicolons to separate rows. Separator characters may be different depending on your country settings.

- Note that the $y$-values predicted by the regression equation may not be valid if they are outside the range of the $y$-values you used to determine the equation.

\section{Example 1 Slope and $Y$-Intercept}

$\operatorname{LINEST}(\{1,9,5,7\},\{0,4,2,3\})$ equals $\{2,1\}$, the slope $=2$ and $y$-intercept $=1$

\section{Example 2 Simple Linear Regression}

Suppose a small business has sales of $\$ 3,100, \$ 4,500, \$ 4,400, \$ 5,400, \$ 7,500$, and $\$ 8,100$ during the first six months of the fiscal year. Assuming that the values are entered in the range $B 2: B 7$, respectively, you can use the following simple linear regression model to estimate sales for the ninth month.

$\operatorname{SUM}(\operatorname{LINEST}(B 2: B 7) *\{9,1\})$ equals $\operatorname{SUM}(\{1000,2000\} *\{9,1\})$ equals $\$ 11,000$

In general, $\operatorname{SUM}\left(\{m, b\}^{*}\{x, 1\}\right)$ equals $m x+b$, the estimated $y$-value for a given $x$-value. You can also use the TREND function.

\section{Example 3 Multiple Linear Regression}

Suppose a commercial developer is considering purchasing a group of small office buildings in an established business district.

The developer can use multiple linear regression analysis to estimate the value of an office building in a given area based on the following variables.

Variable

Refers to the

$\mathrm{y}$

$\times 1$

Assessed value of the office building

$\times 2$

Floor space in square feet

$\times 3$

Number of offices

$x 3$
$\times 4$

Number of entrances

$x 4 \quad$ Age of the office building in years

This example assumes that a straight-iine relationship exists between each independent variable ( $x 1$, $x 2, x 3$, and $x 4$ ) and the dependent variable $(y)$, the value of office buildings in the area. 

buildings and obtains the following data.

\begin{tabular}{|c|c|c|c|c|c|c|}
\hline 2 & $\mathrm{~A} \quad \mathrm{Q}$ & 18 & $\mathrm{P}^{2}$ & 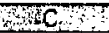 & Do & EE \\
\hline 1 & Floor Space & $\begin{array}{l}02 \\
\text { Offices }\end{array}$ & & $\begin{array}{l}\times 3 \\
\text { Entrances }\end{array}$ & $\begin{array}{l}x 4 \\
\text { Age }\end{array}$ & Velue \\
\hline 2 & 2,310 & & 2 & 2 & 20 & $\$ 142,000$ \\
\hline 3 & 2,333 & & 2 & 2 & 12 & $\$ 144,000$ \\
\hline 4 & 2,356 & & 3 & 1.5 & 33 & $\$ \uparrow \$ 1,000$ \\
\hline 5 & 2,379 & & 3 & 2 & 43 & $\$ 150,000$ \\
\hline 6 & 2,402 & & 2 & 3 & 53 & $\$ 139,000$ \\
\hline 7 & 2,425 & & 4 & 2 & 23 & $\$ 169,000$ \\
\hline 86 & 2,448 & & 2 & 1.5 & 99 & $\$ 126,000$ \\
\hline 9 & 2,471 & & 2 & 2 & 34 & $\$ 142,900$ \\
\hline 10 & 2,494 & & 3 & 3 & 23 & $\$ 163,000$ \\
\hline 11. & 2,517 & & 4 & 4 & 55 & $\$ 169,000$ \\
\hline 12 & 2,540 & & 2 & 3 & 22 & $\$ 149,000$ \\
\hline
\end{tabular}

"Half an entrance" means an entrance for deliveries only. When entered as an array, the following formula:

LINEST (E2:E12, A2 :D12, TRUE, TRUE)

returns the following output.

\begin{tabular}{|c|c|c|c|c|c|}
\hline 48 & 3 & Fed & $\mathrm{C}, \mathrm{s}$ & D: & DETh: \\
\hline 14 & -234.23716 & 2553.21066 & 12529.7682 & 27.6413874 & 52317.8305 \\
\hline 15 & 13.2680115 & 530.669152 & 400.066838 & 5.42937404 & 12237.3616 \\
\hline 16 & 0.99674799 & 970.578463 & HNSB. & HNIA & \#NSA \\
\hline 17 & 459.753674 & 6 & \#NSA & \#NIA & \#NIA \\
\hline 18 & 1732393319 & 5652135.32 & \#N/A & $\# N / \bar{A}$ & \#NA \\
\hline
\end{tabular}

The multiple regression equation, $y=m 1^{*} \times 1+m 2^{*} \times 2+m 3^{*} \times 3+m 4^{*} x 4+b$, can now be obtained using the values from row 14 :

$y=27.64^{\star} \times 1+12,530^{*} \times 2+2,553^{*} \times 3+234.24^{*} x 4+52,318$

The developer can now estimate the assessed value of an office building in the same area that has 2,500 square feet, three offices, and two entrances and is 25 years old, by using the following equation:

$y=27.64^{\star} 2500+12530^{*} 3+2553^{\star} 2-234.24^{\star} 25+52318=\$ 158,261$

You can also use the TREND function to calculate this value. For more information, see TREND

\section{Example 4 Using The F And R2 Statistics}

In the previous example, the coefficient of determination, or $\mathrm{r} 2$, is 0.99675 (see cell $A 16$ in the output for LINEST), which would indicate a strong relationship between the independent variables and the sale price. You can use the $F$ statistic to determine whether these results, with such a high $r 2$ value, occurred by chance.

Assume for the moment that in fact there is no relationship among the variables, but that you have drawn a rare sample of 11 office buildings that causes the statistical analysis to demonstrate a strong relationship. The term "Alpha" is used for the probability of erroneously concluding that there is a relationship.

There is a relationship among the variables if the F-observed statistic is greater than the F-critical value. The F-critical value can be obtained by referring to a table of $F$-critical values in many statistics textbooks. To read the table, assume a single-tailed test, use an Alpha value of 0.05 , and for the degrees of freedom (abbreviated in most tables as $v 1$ and $v 2$ ), use $v 1=k=4$ and $v 2=n-(k+1)=$ $11-(4+1)=6$, where $k$ is the number of variables in the regression analysis and $n$ is the number of data points. The $\mathrm{F}$-critical value is 4.53 .

The F-observed value is 459.753674 (cell A17), which is substantially greater than the F-critical value 


\section{CALCULATION SHEET}

BY: Rod Gimpel

DATE: $05 / 30 / 02$

SUBJECT: Determining the LAW Glass Former Constituents and Amounts for G2 and ACM Models
ORP-56511, Rev. B

PROJECT: RPP-WTP

JOB NO.: 24590

CALC NO.:24590-LAW-M4C-LFP-00002

SHEET REV: B

SHEET NO.: $\underline{66}$

of 4.53. Therefore, the regression equation is useful in predicting the assessed value of office buildings in this area.

\section{Example 5 Calculating The T-Statistics}

Another hypothesis test will determine whether each slope coefficient is useful in estimating the assessed value of an office building in example 3 . For example, to test the age coefficient for statistical significance, divide -234.24 (age slope coefficient) by 13.268 (the estimated standard error of age coefficients in cell A15). The following is the t-observed value:

$\mathrm{t}=\mathrm{m} 4 \div \mathrm{se} 4=-234.24 \div 13.268=-17.7$

If you consult a table in a statistics manual, you will find that t-critical, single tail, with 6 degrees of freedom and Alpha $=0.05$ is 1.94 . Because the absolute value of $t, 17.7$, is greater than 1.94 , age is an important variable when estimating the assessed value of an office building. Each of the other independent variables can be tested for statistical significance in a similar manner. The following are the t-observed values for each of the independent variables.

Variable

Floor space

Number of offices

Number of entrances

Age t-observed value

5.1

31.3

4.8

17.7

These values all have an absolute value greater than 1.94; therefore, all the variables used in the regression equation are useful in predicting the assessed value of office buildings in this area. 
SUBJECT: Determining the LAW Glass Former Constituents and Amounts for G2 and ACM Models SHEET REV: $B$ SHEET NO:: $\underline{67}$

\section{Attachment 9}

\section{Linear Curve Fit of LAW Pilot Runs}

Page 1 Excerpt Table 24, Recipe for the Envelope B Feeds Tested, from Final Report, VSL-01 R3520-1, LAW Simulants and Melter Feeds, The Catholic University of America, Vitreous State Laboratory. This table used to calculate volume increase in feed due to glass former addition.

Page 2 Liner Curve Fit of data presented in Table 24. 


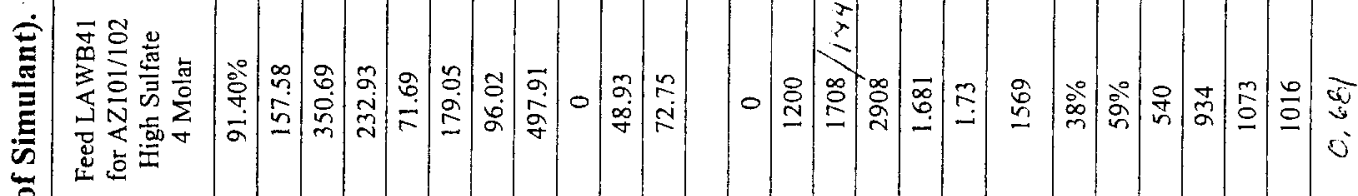

융응

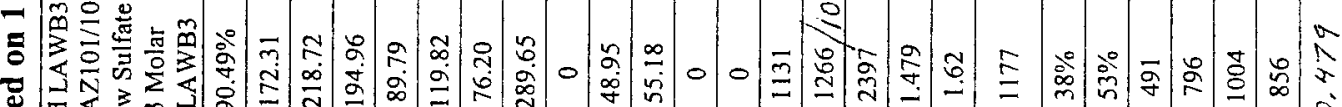

要这

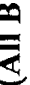

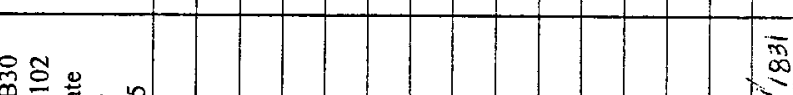

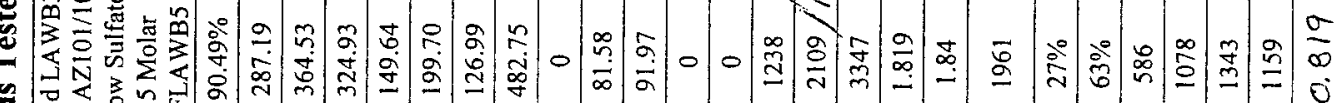

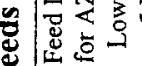


BY: Rod Gimpel

CALC NO.:24590-LAW-M4C-LFP-00002

DATE: 05/30/02

SHEET REV: $B$

SUBJECT: Determining the LAW Glass Former Constituents and Amounts for G2 and ACM Models

SHEET NO: 69

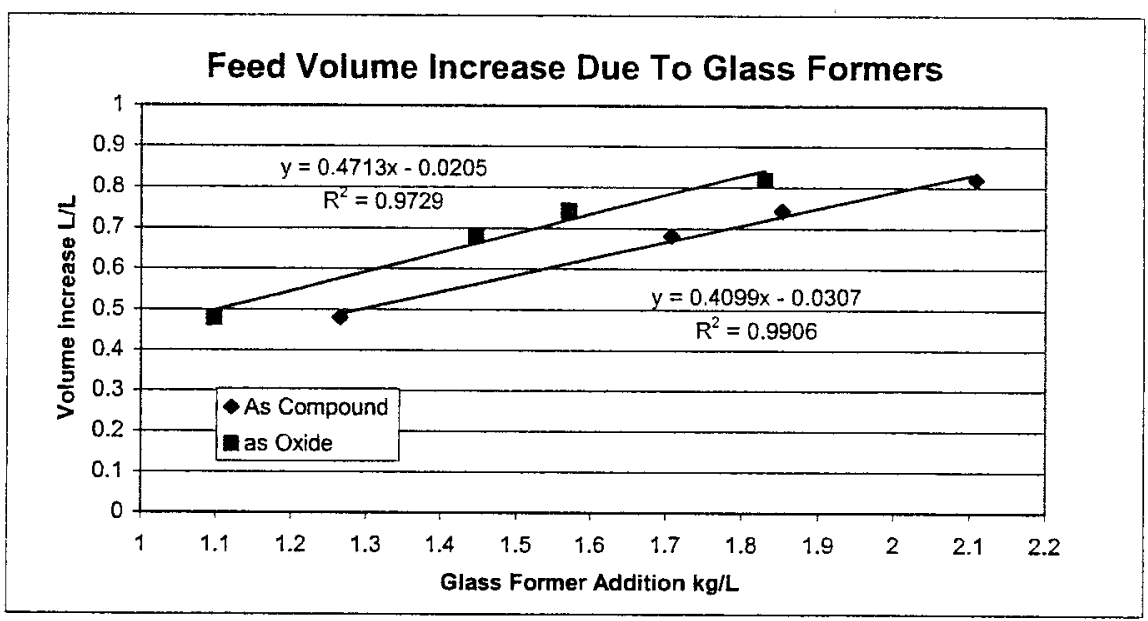

Volume Increase, L/L

GF Additives, $\mathrm{kg} / \mathrm{L}$ as Compounds

as Oxides

$\begin{array}{lll}1.266 & 0.479 & \\ 1.708 & 0.681 & \\ 1.854 & 0.742 & \\ 2.109 & 0.819 & 0.479 \\ 1.098 & & 0.681 \\ 1.447 & & 0.742 \\ 1.572 & & 0.819 \\ 1.831 & & \end{array}$


BY: Rod Gimpel

\section{Attachment 9 (Continued)}

\section{Linear Curve Fit of LAW Pilot Runs}

(One Page) 
BY: Rod Gimpel

CALC NO.:24590-LAW-M4C-LFP-00002

DATE: 05/30/02

SHEET REV: $B$

SUBJECT: Determining the LAW Glass Former Constituents and Amounts for G2 and ACM Models

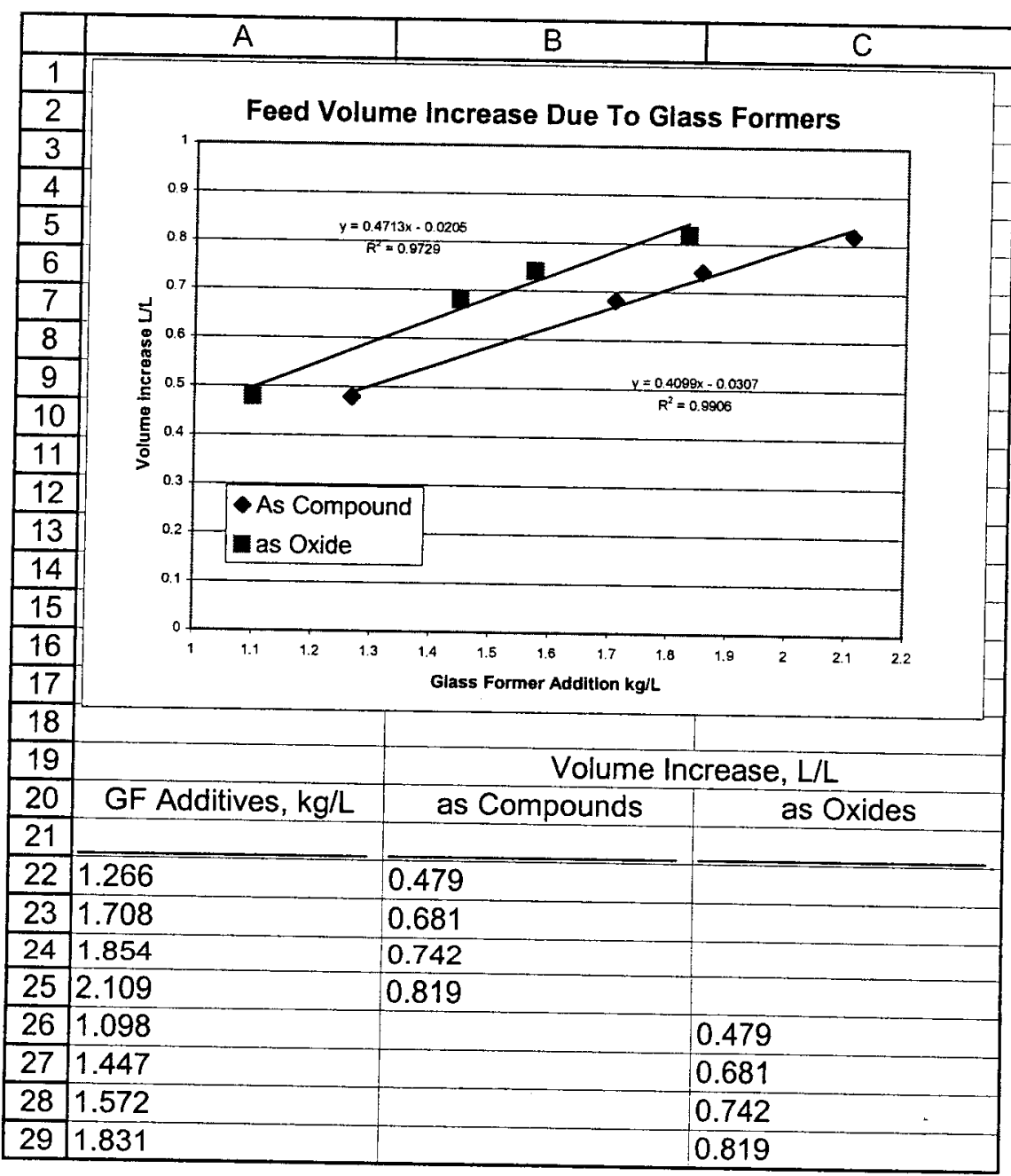

